\title{
A konvektív instabilitás tanulmányozása homogén és pórusos közegben a klorit-tetrationát rendszerben
}

\author{
Doktori $(\mathrm{PhD})$ értekezés
}

\section{Schuszter Gábor}

Témavezetôk: Dr. Tóth Ágota és Dr. Horváth Dezső

Kémia Doktori Iskola

SZTE TTIK

Fizikai Kémiai és Anyagtudományi Tanszék

Szeged, 2013 


\section{Tartalomjegyzék}

1. Bevezetés 1

2. Irodalmi áttekintés 4

2.1. A frontreakciók és jellemzőik . . . . . . . . . . . . . . . . . . . 4

2.2. A konvektív instabilitás kialakulásának lehetőségei . . . . . . . . . . . 5

2.3. A pórusos közeg áramlást befolyásoló hatása . . . . . . . . . . . . . . 9

2.4. A klorit-tetrationát rendszer . . . . . . . . . . . . . . . . . . . . . . . 10

2.5. A részecske-képen alapuló sebesség-meghatározási módszer . . . . . . . . 11

3. Célkitúzés 15

4. Kísérleti rész 17

4.1. Oldatkészítés . . . . . . . . . . . . . . . 17

4.2. A kísérleti elrendezések . . . . . . . . . . . . . . . . . . . . . 18

4.2.1. A homogén közeg tanulmányozása . . . . . . . . . . . . . . . . 18

4.2.2. A pórusos közeg tanulmányozása . . . . . . . . . . . . . . . 19

4.2.3. Az áramlási mezőt feltérképező rendszer . . . . . . . . . . . . . 19

4.3. A kísérlet kivitelezése . . . . . . . . . . . . . . . . . . . . . . . . . . 20

5. Kiértékelési módszerek 22

5.1. A frontprofil és a frontsebesség meghatározása . . . . . . . . . . . . . 22

5.2. A keveredési hossz és az átlagos frontalak definiálása . . . . . . . . . . . . 24

5.3. A részecske-képen alapuló sebesség-meghatározás . . . . . . . . . . . 26

6. Eredmények 28

6.1. A hőmérséklet és a reakciótér méretének hatása . . . . . . . . . . . . . 28

6.2. A pórusos közeg jellemzése . . . . . . . . . . . . . . . . . . 35

6.2.1. A porozitás meghatározása . . . . . . . . . . . . . . 35

6.2.2. A permeabilitás meghatározása . . . . . . . . . . . . 39

6.3. A pórusos közeg hatása . . . . . . . . . . . . . . . . . . . 43 
6.4. A skálázási törvény érvényessége . . . . . . . . . . . . . . . . . . . . 48

6.5. Az áramlási mező meghatározása . . . . . . . . . . . . . . . . . . . 50

7. Összefoglalás 53

$\begin{array}{ll}\text { 8. Summary } & 57\end{array}$

$\begin{array}{ll}\text { Irodalomjegyzék } & 61\end{array}$

$\begin{array}{ll}\text { Köszönetnyilvánítás } & 67\end{array}$ 


\section{1. fejezet}

\section{Bevezetés}

Hétköznapi életünk során lépten-nyomon találkozunk olyan folyamatokkal, melyekben anyag áramlik egyik helyrôl a másikra. Mindenki számára ismert, hogy a vízforraló nemcsak a vele közvetlen érintkezésben levô vízréteget melegíti fel, hanem a teljes folyadékot. Ennek oka - a hôvezetés mellett - az, hogy a melegebb víz súrúsége kisebb mint a hidegebbé, ezért egy folyamatos keveredés jön létre a rétegek között, tehát egy idő után a folyadék minden része érintezik a fútőszállal. Régóta tudjuk azt is, hogy az emberi testben vér cirkulál a szív ritmikus összehúzódásának és elernyedésének köszönhetően, és ezáltal biztosított a különböző anyagok, mint például az oxigén szállítása a sejtekhez és a szövetekhez. Az életünk szempontjából - most már - szinte nélkülözhetetlen vezetékes víz vagy üzemanyag is áramlás révén jut el a kitermelés helyérôl a közvetlen környezetünkbe. Az említett néhány példából is egyértelmú, hogy az anyag-transzportfolyamatok tanulmányozása, részletekbe menô megismerése alapfeltétele életszínvonalunk hosszútávú fenntartásának, ám mindemelett rendkívül érdekes és gazdag információforrás a kutatók számára, ezért is foglalkoznak vele oly sokan.

Az anyag-transzportfolyamatok hajtóereje különböző, míg a részecskék diffúzióját a koncentrációgradiens vezérli, addig az ionok elektromos térben a töltésüknek megfelelő irányba migrációval is mozognak, gravitációs erôtérben pedig az egész közegre kiterjedő áramlás (konvekció) alakulhat ki. A közegmozgás tanulmányozásakor a viszkozitás, a felületi feszültség, és a sûrúségkülönbség által indukált hatásokat kell szem előtt tartani. Ezen jelenségek közül talán a legismertebb a „,bor könnye”, ahol az alapvető hajtóerô a bort alkotó víz és alkohol felületi feszültségének, valamint párolgási sebességének különbsége. A folyadékok viszkozitása közötti eltérést igyekeznek kihasználni például a kőolaj másodlagos kitermelésekor, amikor megfelelő összetételú vizes oldatot préselnek a tározó közetbe, hogy ezáltal megnövelve a nyomást, az olaj kiáramlása szintentartható legyen.

Munkám során az érintkező folyadékok közötti sưrúségkülönbség hatására kialakuló konvekció jelenségét vizsgáltam részletekbe menően. Közismert tény, hogy ha izoterm körülmények között, nagyobb sûrúségú folyadék tetejére rétegzünk kisebb sûrúségú folyadé- 


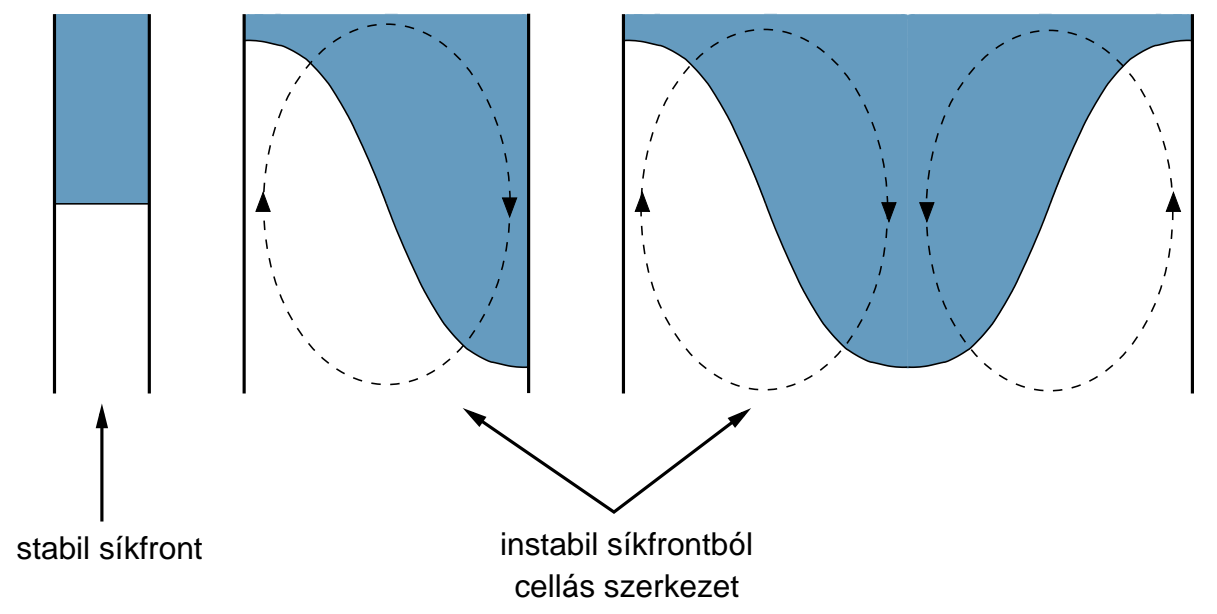

1.1. ábra. A konvekció kialakulásának szemléltetése vízszintes határfelülettel elválasztott folyadékok esetén. Fehér színnel a kisebb, kék színnel a nagyobb súrúségú folyadékot jelöltem.

kot, akkor a kialakuló határfelület megôrzi hidrodinamikai stabilitását. Az már kevésbé egyértelmú, hogy stabil, sík határfelületet kapunk akkor is, ha elegendôen keskeny résben nagyobb sûrûségú folyadékot öntünk a kisebb sûrűségú tetejére. Ennek oka abban keresendő, hogy nincs elég hely az áramlási zóna kialakulásához, valamint a fal mentén fellépő súrlódás, és a folyadék határfelületi felületi feszültsége kiegyenlíti a lefelé mozgást biztosító súlyerôt. Amennyiben növeljük a rés vastagságát, egy kritikus résméret felett a nagyobb sưrúségú folyadék elkezd lefelé süllyedni és kiszorítja onnan a másikat, amely így felfelé áramlik, ezáltal konvekció indukálódik. A konvekció jellemzésére a konvekciós gyưrút használjuk, melynek száma nô a rés méretének növelésével. Az imént leírtak megértését az 1.1. ábra segíti, amelyrôl láthatjuk, hogyan változik a két folyadék közötti horizontális, kezdetben sík határfelület a rés méretének növelésével.

A különböző sûrúségú folyadékok közötti függőleges határfelület a rés méretétôl függetlenül minden esetben hidrodinamikailag instabil, így biztosan számolhatunk a konvekció kialakulásával ilyen elrendezés mellett (lásd az 1.2. ábra). A közegmozgásnak ezen fajtájával foglalkozó kutatók körében közkedvelt a frontreakciók használata, melynek oka, hogy a front két oldala, a termékek és a reaktánsok között állandó sû́rúségkülönbség alakul ki. Ennek következménye, hogy a rendszer úgy viselkedik, mintha két eltérô sűrúségú, egymással nem elegyedő folyadék alkotná. Térben és időben lejátszatva bármely autokatalitikus reakció frontreakcióként viselkedik, így ezek alkalmazása igen kényelmes. Autokatalízisről beszélünk, ha a folyamat során keletkező valamely termék a saját képződését elősegíti, katalizálja. Ezen fajta reakciók a nemlineáris dinamika témakörébe tartoznak, mivel mind a koncentrációk mind a reakció sebessége nemlineáris módon változik az idő előrehaladtával. Kísérleteim során a nátrium-klorit és a kálium-tetrationát között végbemenő, hidrogénionra 

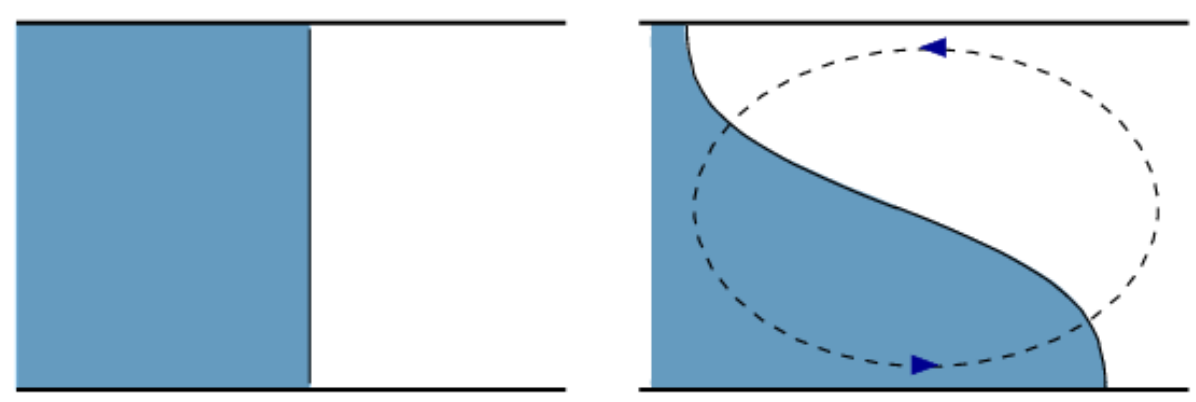

1.2. ábra. A konvekció kialakulásának szemléltetése függőleges határfelülettel elválasztott folyadékok esetén. Fehér színnel a kisebb, kék színnel a nagyobb sưrúségú folyadékot jelöltem.

nézve autokatalitikus reakciót használtam vízszintesen haladó, kezdetben függóleges frontokat indítva. Ezen rendszer segítségével vizsgáltam a konvektív instabilitást mind homogén, mind pórusos közegben, ezáltal is egy lépéssel közelebb kerülve a hétköznapi életben lejátszódó folyamatokhoz. A dolgozatomban a mérésekkel kapcsolatos eredményeimet fogom bemutatni, értelmezni. 


\section{2. fejezet}

\section{Irodalmi áttekintés}

\subsection{A frontreakciók és jellemzôik}

Az anyag-transzportfolyamatok kifejezés magában foglalja a diffúzió, a migráció, és a konvekció jelenségét is. Doktoranduszi munkám során a konvekciót vizsgáltam részletekbe menően, ám ennek kifejtéséhez szükséges néhány szót ejteni a diffúzióról és a vizsgálatával kapcsolatos eredményekről is. A diffúzió az a mozgásforma, mellyel az atomok, ionok, molekulák a térbeli koncentrációeloszlásban levő inhomogenitásokat kiküszöbölni igyekeznek anélkül, hogy maga a közeg mozogna [1]. Egyes kémiai átalakulások mérhető sebességgel csak katalizátor jelenlétében mennek végbe, amennyiben ez a katalizátor a reakció során keletkezik autokatalízisról beszélünk. Ilyen esetekben az adott anyag a reakcióra jellemző empirikus sebességi egyenletben is szerepel. Autokatalitikus reakciókat térben és időben lejátszatva egy - a termékeket és a reaktánsokat elválasztó - kémiai front halad végig a reaktánselegyen, annak teljes elfogyásáig [2]. A kémiai frontreakciókra R. Luther hívta fel a figyelmet 1906-ban egy Drezdában tartott konferencián. Ôt alapvetôen a biológiai ingerületterjedés kémiai analógiájának megvalósítása érdekelte, és kíváncsi volt, hogy olyan frontot, mint a túlhútött oldat kikristályosodása inícializálás hatására, folyadékfázisban is létre lehete hozni. Az általa kapott eredményeket - mely szerint a front haladási sebessége arányos a folyamat elsôrendú sebességi állandójának és diffúziós állandójának szorzatának négyzetgyökével - Nernst még szkeptikusan bírálta, ám 30 évvel késôbb R. A. Fisher angol matematikus és biológus a mutáns gének populációkbeli terjedésének tanulmányozásakor ugyanerre a megállapításra jutott [3,4]. A kémiai frontreakciókkal kapcsolatos kutatások a felfedezésüket követően majd 80 évvel később lendültek fel, melyekhez előszeretettel használták a jodát-arzénessav, klorit-tioszulfát, klorit-tetrationát, és a vas(II)-salétromsav rendszereket, ám ezek mellett sok egyéb összetétel alkalmas ilyen folyamatok vizsgálatára [5,6]. A front alakját, haladását az autokatalizátor és a reaktánsok diffúziója befolyásolja konvekciómentes körülmények között, melynek mikéntjét széleskörúen tanulmányozták. A vizsgálatok során 
kitértek a résztvevő anyagok diffúziós koefficiensében levő különbségek hatására [7,8], ezek megváltoztatásának kémiai [9-11], illetve fizikai lehetőségeire [12,13]. Elemezték a front görbületének, a kiindulási koncentrációknak, illetve azok arányának, a hőmérsékletnek [14], a közeg porozitásának [15], és a pH-nak a hatását is [16]. A diffúzióval kapcsolatos elméleti és kísérleti eredmények, melyekben frontreakciókat vizsgáltak, itt kapcsolódnak jelen disszertáció témájához, ugyanis a kémiai front két oldala közötti állandó sưrúségkülönbség megfelelő kürülmények között konvektív instabilitás kialakulását eredményezi, melynek fajtáira, és magyarázatára a következőekben térek ki.

\subsection{A konvektív instabilitás kialakulásának lehetôségei}

Az emberiség az áramló folyadékokkal kapcsolatos alapvetô ismereteit már évszázadokkal ezelôtt is igyekezett kiaknázni, amit a római korból fennmaradt vízvezetékek, illetve a középkorban közkedvelten alkalmazott vízimalmok is mutatnak. Ezen tapasztalati alkalmazások nem nyújtanak tudományos szintú magyarázatot a transzportjelenségekre, ehhez az áramlás kiváltó okait kell megvizsgálni. Ha az érintkező folyadékok sưrűsége, viszkozitása, vagy felületi feszültsége eltérô, akkor elegendően széles folyadékhatár esetén konvekció indukálódik.

Először a sưrűségkülönbség kialakulásának lehetőségeire, valamint annak hatására térek ki. A súrúségkülönbség okozta közegmozgással kapcsolatos folyamatok igényes, tudatos vizsgálata az 1800-as évek végén indult Rayleigh (John William Strutt) elméleti munkái alapján [17], aki két folyadék közötti vízszintes határfelület változásait, azaz a felület instabilitását vizsgálta olyan elrendezésben, amikor a nagyobb sưrúségú folyadék van a kisebb sûrúségû́re rétegezve. Ugyanezen témával foglakozva G. I. Taylor megállapította, hogy a különböző sûrúségú folyadékok közötti határfelelület stabilitása, illetve instabilitása a határfelületre merőlegesen ható erővel befolyásolható [18]. Kettejük tiszteletére a gravitációs térben, a folyadékok sûrúségkülönbségének hatására kialakuló instabilitást ma Rayleigh-Taylor instabilitásnak nevezik. D. J. Lewis volt az elsô, aki komoly kísérleti berendezést készített a jelenség vizsgálatához [19], mellyel a nyomás és a felületi egyenetlenségek hatásait sikerült részletekbe menően magyaráznia. Az előbbi kutatásokban közös, hogy két különböző folyadékot használtak, melyek sứrúsége természetszerúen eltért egymástól.

Mint korábban említettem, a kémiai frontreakciók fontos tulajdonsága, hogy a termékek és a reaktánsok közötti sűrűségkülönbség adott kísérleti elrendezés mellett állandó, mely alkalmassá teszi ôket a sûrüségkülönbség okozta konvekció hosszútávú tanulmányozására. Az 1980-as évek végén J. A. Pojman és I. R. Epstein részletesen elemezte és magyarázta a front két oldala közötti sûrúségviszonyokat kialakító tényezőket [20]. Az egyik ok, hogy a reakció során a reaktáns termékké alakul és ezzel az összetétel megváltozik. A sűrúségviszonyokat 
izoterm körülmények között vizsgálva elmondhatjuk, hogy vannak olyan reakciók, melyben a termékoldat sürűsége kisebb mint a reaktánsoké (pl. a jodát-arzénessav rendszer [21]), és ennek ellentettjére is találunk példát (pl. a klorit-tetrationát rendszer, melyrôl részletesen lesz még szó).

A másik ok, melyet ma már mindenki jól ismer, hogy a hőmérséklet változása a sûrűség változását vonja maga után. Amennyiben a hőmérsékleti viszonyok miatt a sứrúségeloszlás a folyadék belsejében nem egyenletes, akkor egy adott folyadékon belül is létrejöhet áramlás. Erre a tényre H. Bénárd francia fizikus figyelt fel [22,23], amikor alulról füthetô lemezre vékony olajréteget öntött, és korpafú spórát szórt a tetejére. A melegítés hatására szabályos hatszögletes mintázat kialakulását tapasztalta, melynek magyarázata, hogy az olaj az alsó rétegben felmelegedett és kitágult, míg a levegővel érintkező része hidegebb, így nagyobb sűrűségú maradt, ami egy jól meghatározott áramlást indukált. Tiszteletére a jelenséget ma Bénárd-instabilitásnak hívják.

Nem csak kívülről történő fútés, hanem a lejátszódó reakció következtében is hőváltozás következhet be, mely szintén a súrúségviszonyok módosulását okozza a reakciófront közvetlen környezetében [24,25]. Egyszerú konvekcióról beszélünk, ha mind az összetétel változása, mind a hőmérsékletváltozás ugyanabba az irányba módosítja a termékoldat sûrúségét, ilyen közegmozgás alakul ki a jodát-arzénessav reakcióban felfelé haladó reakciófront esetén [26]. Ellenkező esetben, ha a két hatás egymással ellentétesen igyekszik befolyásolni a termékoldat sûrúségét, akkor összetett konvekció lép fel [27].

Ezen előzetes megfontolások ismeretében vizsgálták a jodát-szulfit és a bromát-szulfit reakció haladási sebességét változtatva a reakcióedény belső átmérőjét, a függőlegessel bezárt dôlésszögét [28], valamint a reaktánselegyben kialakított pH-gradiens szerepét [29]. A jodát-szulfit reakció esetében a Pojman-Epstein modell alapján egyszerú konvekció megjelenését várták, mivel a reakció exoterm, ezen kívül az izoterm sûrúségváltozás is negatív. Ezzel ellentétben azt találták, hogy a lefelé haladó front sebessége nagyobb volt, mint a felfelé haladóé, és ujjra hasonlító alakzat jött létre. A rendszer alapos tanulmányozása arra a megállapításra vezetett, hogy a reakcióban keletkező kénsavból felszabaduló hidrogénion diffúziós koefficiense jelentősen meghaladja az összes többi jelenlevő anyagét, és így a front közelében ezen hatásnak köszönhetôen is változnak a sûrúségviszonyok, ami a front nem várt gyorsaságát okozza [30]. A jelenséget dupla-diffúzív konvekciónak nevezzük, melyet a későbbiekben más rendszerekben is megfigyeltek [31].

A sưrúségkülönbség okozta konvekciónak a front instabilitására kifejtett hatását sokféle szemszögből kutatták. Böckmann és Müller a jodát-arzénessav rendszert használva vizsgálta a folyadékréteg vastagságának hatását a függőlegesen felfelé haladó front időbeni fejlődésének jellemzésére alkalmas marginális hullámszám és maximális növekedési ráta értékeire [32]. Csoportunkban kellóen széles edényben a klorit-tetrationát rendszert használva a 
lefelé haladó, kezdetben sík front ujjszerű szegmensekre való szétesését tapasztalták, és az ujjak száma a szélességgel nőtt [33]. Ezen kis egységek nagyobbakká egyesültek, amelyek bizonyos méret felett ismét osztódtak. Részletesen tanulmányozták a közeg viszkozitásának hatását a folyamatra [34] és azt figyelték meg, hogy a viszkozitás növekedésével az egycellás alakzat csak egyre nagyobb folyadékszélességek esetén jelenik meg. A reakciót termosztálva - a hőmérséklet okozta sűrúségváltozást eliminálva - az ujjak száma nem, de azok mérete jelentősen megnőtt [35]. A jodát-arzénessav rendszerben a sûrúségkülönbség miatti ujjasodás elméleti magyarázatához a folyadék áramlási viszonyait a részecske-képen alapuló sebesség-meghatározási módszert használva tanulmányozták, majd szimulációval a rétegek jellemző mozgását lényegileg jól visszaadták [36]. A jelenséget elméleti úton pórusos közegben is vizsgálták a II. Damköhler szám (a hidrodinamikai és a kémiai idôskála hányadosa) változtatásán kersztül [37] és azt állapították meg, hogy növelve a reakció hozzájárulást a folyamatokhoz az instabilitás mértéke nő, a kialakulásához szükséges idő pedig csökken. Mind kísérleti, mind elméleti úton megfigyelték, hogy a front haladási irányának függőlegessel bezárt szöge befolyásolja a terjedési sebességet [38], ami teljes összhangban van a korábban I. Nagypál és munkatársai által meghatározott értékekkel [25].

Az eddigiekben kísérleti úton még csak kevéssé vizsgálták a függőlegesen inicializált, vízszintesen haladó reakciófrontok viselkedését. Tudjuk, hogy ilyen körülmények között a reaktánsokat és a termékeket elválasztó határvonal minden esetben eltér a függőlegestôl. Doktori munkám egyik célja ezen eltérésnek a kvantitatív feltérképezése volt, kitérve a kiindulási koncentrációk, az oldat magasság és vastagság, a hőmérséklet, valamint a pórusos közeg alkalmazásának hatására [39-41]. Az oldatréteg vastagságának a korábbiakhoz képesti jelentős mértékú növelésével háromdimenziós áramlás kialakulására nyílik lehetőség, amit egyszerú konvekciót [42], és összetett konvekciót [43] mutató rendszerekben is tanulmányoztak. Jelen disszertáció másik fontos eredménye a klorit-tetrationát rendszer háromdimenziós áramlási profiljának feltérképezése volt adott kísérleti körülmények között.

A témával kapcsolatban számos elméleti kutatást is végeztek. Már az 1990-es évek elején háromdimenziós stabilitásvizsgálatot hajtottak végre autokatalitikus reakciókat modellezve, ahol a front változásának jellemzésére egy úgynevezett kulcsparamétert használtak, amely a sûrúségviszonyoktól, a viszkozitástól, a gravitációs gyorsulástól, a diffúziós állandóktól és a reakciótér méreteitôl függött [44]. Figyelembe véve a folyadékoszlop nagyságának a frontsebességre kifejtett hatását számításokkal megmutatták, hogy a sebesség növekedése a reakció-diffúzió és a hidrodinamikai viszonyok összekapcsolásának eredménye [45]. Ezen korai elméleti munkáknál még vékonyfront-közelítést alkalmaztak, vagyis a súrúségváltozást csak a front vonalában vették figyelembe. A. De Wit szimulációi során már az egész közeget elhanyagolásmentesen kezelte, és így hasonlította össze az eredményeit [46,47] a kísérleti értékekkel [32,48], melyek jó egyezést mutattak. Számításokkal igazolták azt is, hogy a 
reaktánsok és a termékek diffúziós koefficienseiben levő nagy különbség szintén destabilizáló tényezőként jelenik meg [49], ahogyan ezt kísérletileg korábban tapasztalták is a már említett jodát-szulfit reakcióban. Azt is megmagyarázták, hogy a folyadék rétegvastagsága hogyan befolyásolja a konvekció erősségét, illetve hogy a Reynolds szám előjelváltása miként változtatja az áramlás irányát. A tudományterülettel kapcsolatosan megjelent elméleti és kísérleti munkák precíz összegzését és rendszerbe foglalását D‘Hernoncourt és munkatársai tették meg [50].

Amint korábban említettem, eltérő viszkozitású fluidumok érintkezésekor is kialakulhat a konvektív instabilitás, és a következókben az ezen jelenséggel foglalkozó szakirodalomban fellelhetô eredményeket mutatom be. Az áramló folyadékok viszkozitásától és sűrüségviszonyaitól függő viselkedést pórusos közegben S. Hill vizsgálta cukoripari technológiai megfontolások alapján [51], melyből kiindulva G. I. Taylor és P. G. Saffman a viszkózus ujjasodás jelenségét tanulmányozta Hele-Shaw edényben [52], amely a kialakított rés mérete alapján a pórusos közeget volt hivatott biztosítani. A folyamatban kifejlődő mintázatok elméleti vizsgálatát az 1990-es évek végén végezte el A. De Wit és G. M. Homsy [53, 54]. Számolások útján megmutatták, hogy a közeg pórusmérete hogyan befolyásolja az áramlást, mikor segíti az alakzatok növekedését és mikor vezet csatornák kialakulásához. Ezen eredmények ipari megfontolások alapján is fontosak, hiszen a közegek érintkezését befolyásolják. Kísérleti munkák alapján elmondható, hogy az ujjasodás megjelenése az áramlási sebességtôl és a viszkozitások arányától függ [55]. Amennyiben a kritikus értékek alatt tartjuk ezen paramétereket csak egy egycellás struktúrát kapunk, ám ezen küszöb felett kisebb ujjak jönnek létre. A témával foglalkozva azt is megállapították, hogy a termékek és a reaktánsok között fennálló viszkozitás és sưrúségkülönbség hatására kialakuló alakzat nagysága és haladási sebessége becsülhetố a reakcióedény kiterjedésének, arányainak ismeretében [56].

A harmadik tulajdonság, mely az érintkező fluidumok határfelületét befolyásolja, és közegmozgást hoz létre a felületi feszültség. A jelenséget először C. Marangoni, olasz származású fizikus, írta le 1865-ben elkészült doktori disszertációjában, melyet a megfigyelés tárgya alapján „a bor könnye” néven ismer a szakirodalom [57]. A folyamat lényege, hogy a borban két különböző mértékben párolgó, és eltérő felületi feszültségú folyadék van jelen. A pohár falához közel, a folyadék-levegó határfelületnél, ahol az alkohol jelentôsen párolog, az oldat az alkoholra nézve hígul. A víz felületi feszültsége meghaladja az alkoholét, ezért a bor belsejéből folyamatosan alkohol áramlik az adott térrészbe, ahol el is párolog, majd egy adott koncentrációt elérve a pohár hideg falán lecsapódik, és súlyánál fogva visszafolyik a tömbfázisba. Ezen folyamat kémiai reakciók esetén is felléphet, melynek pontos elméleti leírását L. Rongy és A. De Wit végezte el. Modelljükben vékony edényben, reakció-diffúzióval haladó frontot vizsgáltak izoterm körülmények között, feltételezve, hogy a termékek és a reaktánsok sûrúsége megegyezik. Elemezték, hogy a reakcióban keletkező felületaktív anyag 
hogyan befolyásolhatja párolgásmentes körülmények között az egyébként sík határfelületet. Megállapították, hogy ha a termék felületi feszültsége kisebb mint a reaktánsoké, akkor a fellépő konvekció erősebben deformálja a frontot mint ellenkező esetben, illetve mind a két esetben meghatározták az állandósult alakzat létrejöttéhez szükséges idôt is [58-60].

\subsection{A pórusos közeg áramlást befolyásoló hatása}

A korábbiakban a pórusos közeg által az autokatalitikus reakciófrontok haladási sebességére és alakjára kifejtett hatást kísérletileg csak kevéssé vizsgálták. Áramlásmentes körülmények között elemezték a homogénből a pórusos közegbe való átmentetet olyan rendszerekben, ahol a kémiai front mozgását csak a reakció-diffúzió idézte elő [15]. A kísérletekhez fotopolimerek segítségével előállított, közel kétdimenziós pórusos közeget használtak, melyben a pórusok mérete, és azok elhelyezkedése tetszőlegesen változtatható volt egy számítógépes program segítségével. A klorit-tetrationát reakciót termosztált edényben lejátszatva, függólegesen lefelé haladó front esetén azt tapasztalták, hogy a porozitás csökkenésével az alakzatra jellemző maximális hullámszám értéke csökkent. D. Salin és csoportja is végzett néhány kísérletet pórusos közegú frontreakciók esetén [61-63], ám ezekben a front ellenében, vagy éppen a vele megegyező irányban történő reaktáns-áramoltatás hatását vizsgálták a jodátarzénessav rendszerben. A közeg kialakításához kétféle méretú gyöngy keverékét használták, és megállapították, hogy a permeabilitás növekedésével nőtt a front terjedési sebessége. Ezen kívül elemezték a mozgó folyadék útjába helyezett akadály körül kialakuló áramlási teret is.

A. De Wit és S. S. S. Cardoso elméleti számításokat hajtott végre pórusos közeget feltételzve, de ilyenkor rendszerint maga a közeg homogén volt, csak a folyadék vastagsága volt hivatott a pórusos közegnek megfelelő körülményeket képviselni. Közleményeik fố mondanivalója nem a pórusos közegre, hanem a benne kialakuló viszkózus ujjasodásra [53,54], a sûrûségkülönbség miatti ujjasodásra [37], és a konvekció kialakulásának mikéntjére [64] irányult. Ez utóbbi kutatás fontos gyakorlati szempontra hivatkozva vizsgálja a témát, úgyanis a mélytengerekben végezhető szén-dioxid tárolás esetleges nehézségeit tanulmányozza. A besajtolt gáz megváltoztatja a folyadékréteg sûrúségét, ami konvekciót indukálhat, és ezáltal nem kívánt gázfelszabadulást is eredményezhet.

Annyi bizonyos, hogy a közeg pórusos vagy homogén volta befolyásolja a rajta keresztuil történő közegmozgást, hiszen ezt többen is megfigyelték, gondoljunk csak a már említett S. Hill cukoripari vizsgálataira [51]. Ám hogy a közegnek milyen hatása van a kémiai mintézatképződésre, ha konvekcióval is számolnunk kell és külsô áramoltatás nincs, az még a tudomány fehér foltjai közé tartozik, éppen ezért a jelen disszertáció egy része ilyen kísérleti elrendezésû reakciók tanulmányozásának eredményeit taglalja. 


\subsection{A klorit-tetrationát rendszer}

Miután a kémiai frontreakciókkal kapcsolatos vizsgálatok nagy érdeklődésre tettek szert, célszerú volt meghatározni azon reaktánsok körét, melyek megfelelő körülmények között ilyen viselkedést képesek mutatni [5,6]. A klorit és a tetrationát ion között végbemenô reakció is ezek közé tartozott, olyannyira, hogy ezen reakció esetén mérték a legnagyobb frontsebességet, ugyanakkor a reaktánselegy mégis jónak mondható stabilitással rendelkezett, vagyis a spontán beindulás mértéke csekély. Rendkívül előnyös tulajdonságai ellenére a kezdeti idôkben a folyamat mégsem vált a témával foglalkozó kutatók elsődleges célpontjává, melynek oka talán a bonyolult mechanizmusában keresendő. A reakció sebessége a kloridion-koncentrációval kis mértékben nő, valamint a folyamat hidrogénionra nézve másodrendû vagyis összességében szuperkatalitikus. Ecetsav-acetát pufferben végezve a méréseket (a reakciósebesség protonkoncentrációtól való függését elnyomva) azt tapasztalták, hogy kis klorit koncentráció esetén a folyamat autokatalitikus módon játszódik le, míg nagy koncentrációknál a reakció egy nemautokatalitikus úton megy végbe, és a sebessége a klorit koncentrációjával nő [65]. A két lehetséges út közötti váltást a klorit saját-inhibíciója okozza, ha megfelelố mennyiségben van jelen. A reakció teljes mechanizmusát [66], illetve a tetrationátion lúgos közegú bomlását Horváth Attila vizsgálta részletekbe menően fotometriás módon [67]. Munkája eredményeként egy 14 lépésből álló reakciórendszert épített fel. Jelen disszertáció témájának leírásához szükségtelen ezen lépések ismerete, mivel ezek a front mögött lemaradva mennek végbe, így tulajdonságait nem befolyásolják. Elégséges, ha a folyamatot az alábbi modellreakcióval jellemezzük:

$$
7 \mathrm{ClO}_{2}^{-}+2 \mathrm{~S}_{4} \mathrm{O}_{6}^{2-}+6 \mathrm{H}_{2} \mathrm{O}=7 \mathrm{Cl}^{-}+8 \mathrm{SO}_{4}^{2-}+12 \mathrm{H}^{+}
$$

A reakció sebességi egyenlete

$$
r=-\frac{1}{7} \frac{\mathrm{d}\left[\mathrm{ClO}_{2}^{-}\right]}{\mathrm{d} t}=k\left[\mathrm{ClO}_{2}^{-}\right]\left[\mathrm{S}_{4} \mathrm{O}_{6}^{2-}\right]\left[\mathrm{H}^{+}\right]^{2}
$$

alakban írható, melyből jól látszik, hogy az átalakulás a hidrogénionra nézve autokatalitikus.

A klorit-tetrationát rendszer már az 1990-es évek közepétôl jelentős érdeklődésre tett szert a kutatócsoportunkban, amit a témával kapcsolatban megjelent publikációk száma is jól mutat. Először olyan körülmények között vizsgálták a folyamatot, amely csak reakciódiffúzió kialakítására nyújtott lehetőséget. A hidrogéniont nátrium-metakrilát segítségével részlegesen megkötötték, ezzel lassítva a diffúziós képességét. Azt tapasztalták, hogy az egyébként stabil front kisebb szegmensekre esik szét, instabillá válik. Egy ötletes kísérlettel azt is megmutatták, hogy ezt a hatást nem a közeg homogenitásának megtörése okozza, hiszen ugyanezen gélben a Belouszov-Zsabotyinszkij reakciót lejátszatva a kifejlődő spirálok 
folytonos szerkezetúek voltak [9]. Ugyancsak a front instabilitását tudták előidézni inhomogén elektromos térben szelektíven lassítva a résztvevő ionokat [13].

A reakciót izoterm körülmények között vizsgálva elmondható, hogy a termékek sûrúsége nagyobb mint a reaktánsoké, ami megfelelő elrendezés mellett a sûrúségkülönbség okozta ujjasodás kialakulásához vezet. A front szerkezete, az ujjak nagysága függ az alkalmazott koncentrációktól (ha nő a kiindulási koncentráció, nő a sưrűségkülönbség), valamint a front szélességétől [33]. Ezt a befolyásoló hatást a közeg viszkozitásának módosításával befolyásolni lehet [34].

A klorit-tetrationát reakció erősen exoterm, amit a reakcióentalpia értéke egyértelmúen mutat $\left(\Delta_{r} H=-3960 \pm 50 \mathrm{~kJ} / \mathrm{mol}\right.$ [48]). A hőmérséklet-változásának a kialakuló mintázatokra gyakorolt hatását függőlegesen haladó frontok esetén vizsgálták, és megállapították, hogy termosztált kísérletek esetén az instabilitás mértéke mind a lefelé, mind a felfelé haladó frontok esetén kisebb, mint a termosztálatlan esetben, ezzel egyértelmú bizonyítékát adták a hőmérséklet okozta konvekciónak [14,35].

A témával kapcsolatban olyan publikáció is megjelent, amelyben egymással szemben indított reakciófrontokat vizsgáltak, és azt tapasztalták, hogy a kiindulási koncentrációktól függően a frontok megálltak egy bizonyos távolságra érve egymástól [68]. Az észlelt jelenség több mint érdekes, bár a pontos magyarázata még várat magára.

A reakciórendszert elméleti számítások útján is vizsgálták, ahol a különböző modellek eredményét igyekeztek a csoportunkban kapott mérési eredményekkel összehasonlítani, és ezáltal feltárni a folyamatok legfontosabb vonásait. A modellek alapján is nyilvánvalóvá vált, hogy a reaktánsok és a termékek sûrúségviszonya jelenti azt a paramétert, amire a mintázatok leginkább érzékenyek, ezt pedig mind a koncentrációval, mind a folyadékvastagsággal változtatni lehet a hôhatás befolyásolásán keresztül [47].

\subsection{A részecske-képen alapuló sebesség-meghatározási mód- szer}

Az emberiség részéről régóta alapvető az a vágy, hogy a tárgyak, közegek mozgását a lehető legjobban megismerje és jellemezze. Nem kell messzire menni példákért, elég ha belegondolunk, hogy már a kisgyerekek is mennyire szeretnek fadarabot vagy éppen hajót tenni a víz felszínére és micsoda örömöt találnak a mozgásuk figyelésében. A folyadékok áramlásával kapcsolatos első igényes (szó szerint múvészi) munkát Leonardo Da Vinci készítette, amikor a vérnek az emberi testben történő keringését próbálta vizualizálni [69]. Az első olyan kísérleti berendezést, amely mozgó folyadékok vizsgálatára volt alkalmas, és a munka célja nem csak egy megfigyelt környezeti jelenség leírása, hanem annak reprodukálása is volt, L. Prandtl alkotta meg 1904-ben [70]. A berendezés egy fából készített, vízszintesen 
két részre osztott vízcsatorna volt, melyben az áramlást egy tekerővel ellátott forgó lapát biztosította. Prandtl különböző alakú akadályokat tett a doboz felső térrészébe és figyelte a körülöttük kialakuló áramlási mintázatokat, melyeket csillám adagolásával tett láthatóvá. Ilyen módon talán mondhatjuk, hogy ő alkotta meg a részecske-képen alapuló sebességmeghatározási módszer alapjait, bár természetesen megfelelő képfelvevő rendszer híján még csak kvalitatív megállapításokat tehetett.

A fluidumok áramlási terének feltérképezése céljából sok különböző kísérleti eljárást fejlesztettek ki a fizikusok [71], melyek jelentős része a fényjelenségeken alapul. Talán mindenki számára ismert a magyar származású Gábor Dénes által felfedezett holográfia, mely szintén alkalmas ilyen feladatok elvégézésére, bár igényes képek készítése csak rendkívül precíz munkával lehetséges a módszer elvéből kifolyólag. Egy másik példa az áramlások interferometriás vizsgálata, mellyel kapcsolatban kifejezetten jól illik a jelen disszertáció témájához Jr. H. Oertel munkája, aki a Rayleigh-Bénárd instabilitás kiábrázolását oldotta meg ezzel a módszerrel. Az interferometriás eljárások hátránya, hogy az adatok kinyerése időigényes, és a pontosság nem megfelelő mindenfajta vizsgálathoz.

Az általunk használt módszer tényleges alapját 1977-ben tették le, bár akkor még Laser Speckle Photography (LSP) néven. A technika lényege, hogy lézerfényt átbocsátva fényszóró részecskéket tartalmazó rétegen, és a megfigyelt területet a lézersíkra merőlegesen megvilágítva egy diffrakciós képhez jutunk, melynek sávjait a Young módszer alapján elemezhetjük. A sávok közötti távolságból a folyadék elmozdulását, két gyors egymásutánban készített kép időkülönbsége alapján pedig az áramlás sebességét határozhatjuk meg. A dolog érdekessége, hogy az említett évben három kutatócsoport, egymástól teljesen függetlenül dolgozta ki ezt az eljárást, ám közülük csak a legkésőbbinek sikerült igazán nívós helyen publikálnia [72-74]. A folyamat egyszerúségét mutatja, hogy az egyik kísérleti megoldás esetén tejes víznek az áramlását figyelték egy egyszerú bürettában, és a tej jelentette a fényszóró részecskéket.

Az alapeljárást továbbfejlesztették, és a méréstechnikának sok változata kialakult, melyet több összefoglaló cikk alapján is nyomon követhetünk [75-77]. Az alkalmazott részecskék mennyisége alapján három típus létezik. Ha kevés (5-10) szemcse jelenik meg a teljes megfigyelt területen, akkor minden egyes részecske mozgását könnyen azonosíthatjuk két egymást követő kép segítségével. Ennek a folyamatnak Particle Tracking Velocimetry (PTV) a neve. Ha rendkívül sok szemcse van egy képen, akkor a már említett LSP technikát alkalmazzuk. A kettő közötti módszert nevezik tipikusan Particle Image Velocimetry-nek (PIV), azaz magyarul részecske-képen alapuló sebesség-meghatározási módszernek. A PIV mozaikszót először 1984-ben használták a szakirodalomban, és a terület egyik legjelentôsebb úttörője és képviselője, R. J. Adrian, a következő módon fogalmazta meg: „PIV means the accurate, quantitative measurement of fluid velocity vectors at a very large number of po- 
ints simultaneously" [77]. Ebben a mondatban tömören benne van minden, amiért a PIV oly közkedveltté vált. A módszerrel pontosan, kvantitatívan, nagy felbontásban és ráadásul egy időben határozhatjuk meg a folyadék áramlási profilját, ami például nem mondható el a Doppler-effektust alkalmazó technikákról, melyek csak egy pontban képesek mérni.

A jelenleg használt eljárás lényege, hogy a fluidum súrúségével közel megegyező súrûségú fényszóró részecskéket (tipikusan néhány $\mu$ m átmérőjü) juttatunk a vizsgálni kívánt közegbe, majd párhuzamos nyalábokból álló lézersíkot bocsátunk rá. A felvételeket a síkra merôlegesen készítjük, részegységekre bontjuk (interrogation window) és számítógép segítségével kiértékeljük [78]. A tudományterület aktuális problémája a lehetô legnagyobb pontosság és a gyors kiértékelés kompromisszuma, ami egy több tízezer vektorral leírt tér esetén komoly feladat. McKenna és McGillis munkájuk során négy különböző kiértékelési módszert vizsgáltak az említett szempontok alapján. A legpontosabb, de egyben a leglassabb módszer a direkt térbeli korreláció, ahol az időben első képen kijelölt négyzet alakú mező korrelációjának maximumát nézik a második képen a mezô körüli keresômezőben. A másik két eljárásban standard Fourier-transzformációt, illetve dinamikus Fourier-transzformációt használtak. Ezek a módszerek gyorsak, ám a pontosságuk messze elmaradt a direkt térbeli korrelációétól. Az előzőek alapján kifejlesztettek egy hibrid eljárást, melyben ötvözték a praktikus tulajdonságokat [79].

Nem csak a kiértékelési módszer helyes megválasztásával, hanem speciális programok írásával és eszközök gyártásával is igyekeznek megfelelő hatékonyságot elérni, amit az is mutat, hogy kifejlesztettek egy algoritmust, ami a számítógép GPU-ját (graphics processing units) használva ötvenszer gyorsabban szolgáltat eredményt, mint a Fourier-transzformációt használó eljárás [80]. Egy másik csoportban egy direkt ilyen számolásokra alkalmas chip-et alkottak meg, bár ennek a gyorsító hatása megkérdőjelezhető mértékú [81].

A következőekben néhány példával illusztrálom a PIV alkalmazhatóságát. Ugyan a kísérletek során síkká expandált lézerfényt használnak, megfelelő berendezés esetén háromdimenziós vizsgálatokra is lehetôség van. Szélcsatornában kialakuló áramlást vizsgáltak oly módon, hogy a lézersíkot egy forgatható tükör segítségével a tér teljes pásztázására használták [82]. Nem kifejezetten tudományos, ám ipari szempontból mégis szükséges méréseket hajtottak végre, amivel a pezsgőspohár kialakítása és a folyadék áramlása közötti kapcsolatot vizsgálták, mely az aromaanyagok legmegfelelóbb kipárolgása miatt volt fontos [83]. Jelen disszertáció témájához sokkal közelebb álló alkalmazással foglalkoztak tudósok nemzetközi kooperáción belül, amikor az IAA rendszerben vizsgálták a Rayleigh-Taylor instabilitás okozta ujjak osztódásának folyamatát felfelé haladó reakciófront esetén [36]. Szintén a folyadékhatár instabilitását tanulmányozták egy neutralizációs sav-bázis reakcióban HeleShaw edényt használva, ahol az elsődleges, ujjas struktúrán belül kialakuló másodlagos szerkezetet is találtak [84]. 
Az említett példák alapján egyértelmú, hogy a PIV egy megfelelő módszer a klorittetrationát reakció háromdimenziós áramlási profiljának meghatározásához, melynek a kísérleti megvalósítását, valamint az alkalmazott kiértékelési eljárást a későbbiekben részletesen be is mutatom. 


\section{3. fejezet}

\section{Célkitúzés}

A közegmozgással foglalkozó elméleti munkák alapjaként szolgáló parciális differenciális egyenletek numerikus megoldása megfelelő diszkretizáció nélkül nem lehetséges. Ezen közelítésekkel viszont hibát viszünk be a számolások alkalmával, ám a feladat leküzdhetővé válik, és a számolásokhoz szükséges gépidő is jelentősen csökkenthetố a megfelelő algoritmus kiválasztásával. A csoportunkban végrehajtott kísérletsorozat fontos célja, hogy a mérések és az elméleti munkák eredményei összevethetôk legyenek a folyamatok megértése, javíthatósága érdekében. A folyadékok áramlását elemző elméleti kutatásokban nagy könnyítést jelent, ha kezdetben vékony rétegek mozgását tanulmányozzuk, mivel ekkor a sebességvektor komponensei az áramlási függvény (stream function) segítségével könnyen meghatározhatók. Az ilyen rendszer kíséreltileg is egyszerúen kialakítható és tanulmányozható, vagyis célszerú választás a témával foglalkozók számára. Anne De Wit és csoportja elméleti számításokra alapozva azt jósolták, hogy a keskeny folyadékrétegben vízszintesen haladó, kezdetben függőleges helyzetű határfelülettel rendelkező frontreakciókban a konvekció hatására létrejövő alakzat hosszútávú jellemzésére használt keveredési hossz arányos az edény magasságának második hatványával [49]. Éppen ezért munkám első részében a skálázási törvény létezésének megmutatása, illetve a tényleges hatványkitevő meghatározása volt a célom a klorit-tetrationát autokatalitikus reakcióban, közel kétdimenziós folyadékrétegeket használva. A kísérletek során szisztematikusan változtattam az oldatréteg magasságát, vastagságát és a reaktánsok kezdeti koncentrációját, hogy a kialakult határfelületet a különböző kísérleti feltételek mellett is kvantitatívan jellemezhessem. A méréseket szobahőmérsékleten és $3{ }^{\circ} \mathrm{C}$-ra termosztálva is elvégeztem, hogy a hômérséklet reakcióra gyakorolt hatásáról is információt nyerjek.

Sok esetben a folyadékok áramlása pórusos közegben történik, ezért a homogén közegú kísérleteken kívül pórusos elrendezés esetén is tanulmányoztam ugyanezen frontreakció viselkedését, változtatva a közeget alkotó részecskék méretét, és elvégeztem a kialakuló frontprofil mennyiségi jellemzését. 
Pópity-Tóth Éva kísérletileg vizsgálta a klorit-tetrationát reakciót háromdimenziós körülmények között, és azt a megállapítást tette, hogy amennyiben a folyadékréteg vastagsága meghalad egy kritikus értéket, a front egy állandó, de összetett alakkal és állandó sebességgel terjed [43]. Munkám során célom volt ezen állandósult alakzat kialakításáért felelős áramlási viszonyok feltérképezése és az ehhez szükséges részecske-képen alapuló sebességmeghatározási módszer elvén múködő kísérleti berendezés összeállítása. 


\section{4. fejezet}

\section{Kísérleti rész}

\subsection{Oldatkészítés}

A reaktánsoldatok készítésekor minimum 99 \%-os analitikai tisztaságú kálium-tetrationátot (Aldrich), valamint nátrium-kloritot (Aldrich, minimum $80 \%$-os technikai tisztaságú) használtam. A szilárd anyag beméréshez a kálium-tetrationát közvetlenül felhasználható volt, míg a nátrium-klorit kétszeri átkristályosítás után érte el a minimum 95 \%-os tisztaságot, amely már megfelelt a kísérletekhez. A tömegmérést Adam AAA 250L típusú analitikai mérleggel hajtottam végre. Az oldatkészítéshez ioncserélt vizet (PURITE RO100) használtam, melynek fajlagos vezetôképessége $1 \mu \mathrm{S} / \mathrm{cm}$ volt. A reaktánsoldat készítésekor mágneses keverőre helyezett főzőpohárba először a vizet mértem be automata pipettával (BIOHIT), majd ehhez adtam az indikátort és a nátrium-hidroxidot. Eleinte kongóvörös indikátort használtam, hogy szabad szemmel is jól látható legyen a reakciófront. Ennek színe pirosról kékre vált az átcsapási tartományban az oldat savasodásával. Azonban indikátorcserére kényszerültem, mert a kongóvörösről megtudtuk, hogy a rákkeltő anyagok közé tartozik (H350 - rákot okozhat), ekkor kezdtem el brómfenolkéket használni, mert ezen indikátor átcsapási tartománya átfed a korábban használtéval (kongóvörös esetén $\mathrm{pH}=3,0-5,2$; míg brómfenolkék esetén $\mathrm{pH}=3,0-4,6$ ), valamint az indikátor cseréje nem okozott változást sem a reakciófront alakjában, sem annak terjedési sebességében, így minden szempontból jó választásnak bizonyult. A brómfenolkék színe liláról sárgára vált a reakció folyamán. Az összekevert víz-lúgindikátor elegyhez hozzáadtam a kálium-tetrationát oldatot, majd lassan a nátrium-kloritot is belefecskendeztem folyamatos keverés mellett. Tapasztalatom szerint az adagolási sorrend betartása és a megfelelő homogenizálás nagyban hozzájárult a reakció spontán lejátszódásának elkerüléséhez. Kísérleteim során több különböző kiindulási koncentrációt alkalmaztam, melyeket a 4.1. táblázatban foglaltam össze. A táblázatból kitűnik, hogy a kloritot mindig feleslegben alkalmaztam a tetrationáthoz képest, amire azért volt szükség, hogy a sztöchiometriai arány szerint szükséges oxidálószer mennyiség biztosan jelen legyen a rendszerben. 
4.1. táblázat. Az alkalmazott kiindulási koncentrációk a reaktánselegyben. A feltüntetett indikátorokat nem egyszerre használtam, hanem vagy az egyik, vagy a másik volt csak jelen az oldatban.

\begin{tabular}{|c|c|c|c|c|}
\hline$\left[\mathrm{K}_{2} \mathrm{~S}_{4} \mathrm{O}_{6}\right] / \mathrm{mM}$ & {$\left[\mathrm{NaClO}_{2}\right] / \mathrm{mM}$} & {$[\mathrm{NaOH}] / \mathrm{mM}$} & {$[$ Kongóvörös $] / \mathrm{mM}$} & {$[$ Brómfenolkék] $/ \mathrm{mM}$} \\
\hline \hline 3,75 & 15 & 2,5 & 0,057 & 0,08 \\
\hline 5,00 & 20 & 2,5 & 0,057 & 0,08 \\
\hline 6,25 & 25 & 2,5 & 0,057 & 0,08 \\
\hline
\end{tabular}

\subsection{A kísérleti elrendezések}

\subsubsection{A homogén közeg tanulmányozása}

Kísérleteimet Hele-Shaw edényt használva végeztem el, amely távtartóval elválasztott két plexi lapból állt, mint az a 4.1. ábrán jól látszik. A reakciótér méreteit a távtartó cserélésével tudtam változtatni. Az így kialakítható rés magassága 1,0;1,5;2,0;2,5;3,0; és 4,0 cm volt, a szélességet pedig 1-5 mm között milliméterenként tudtam állítani. Az edény összeszerelésekor a rétegek közé vazelint fecskendeztem, ami biztosította az edény vízzáróságát és a légbuborékok megjelenésének elkerülését a belsô térben. A felül található nyíláson át töltöttem fel az edényt a reaktánseleggyel egy automata pipetta segítségével.

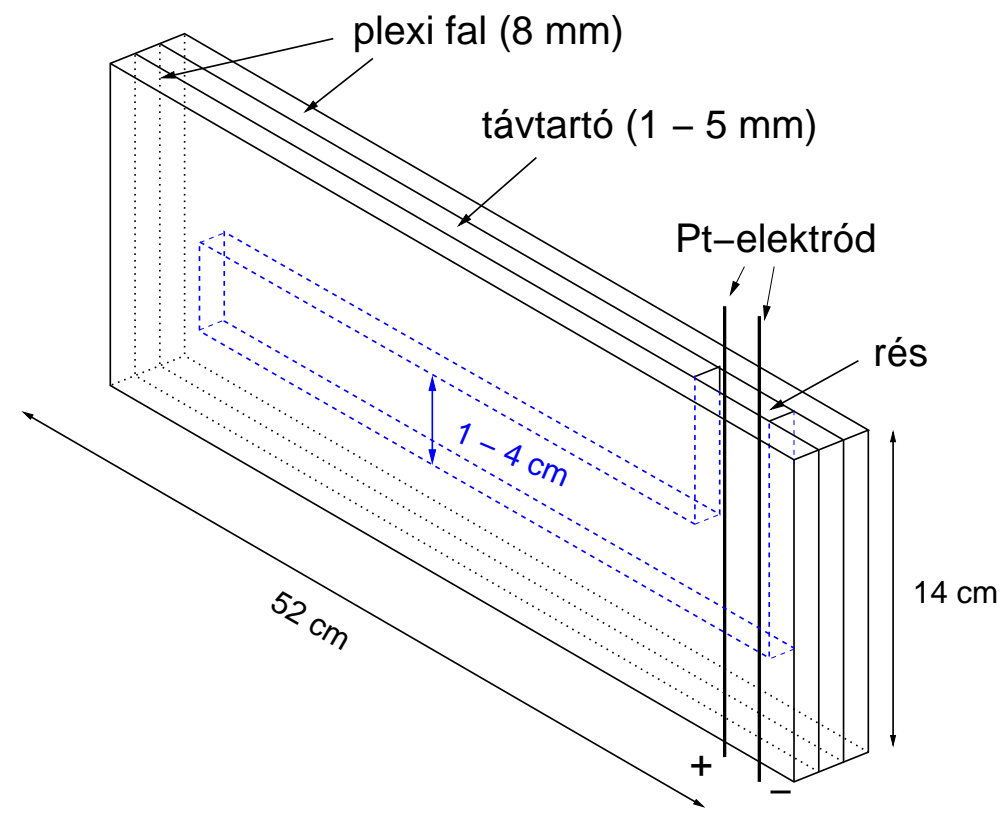

4.1. ábra. Hele-Shaw reakcióedény sematikus rajza. 


\subsubsection{A pórusos közeg tanulmányozása}

A pórusos közeg által a reakciófront alakjára és sebességére gyakorolt hatás vizsgálatához az előbbiekben leírt edényt használtam, az egyetlen különbséget a pórusos közeg kialakítását biztosító boroszilikát gyöngyök (Spektrum-3D) jelentették, ahogyan ezt a 4.2. ábra is jól mutatja. Az egyrétegú, szoros illeszkedés eléréséhez minden távtartónál a vastagságával megegyezô átmérôjű gyöngyöt alkalmaztam. A plexi lapok kismértékú egyenetlensége és a golyók méretbeli apró különbsége lehetetlenné tette a gyöngyök betöltését a reakciótérbe az edény összeszerelése után, így ezeket darabonként, még az összecsavarozás előtt kellett elrendeznem egy csipesz segítségével. Ez aprólékos, sok időt igénylő munka volt, de a rácshibák szinte teljesen kiküszöbölhetővé váltak. A reakcióelegy betáplálására ismét a felső nyíláson keresztuil volt lehetôség, de a buborékmentes feltöltést most nagyban nehezítette a gyöngyök jelenléte, ezért rendszeresen szükség volt óvatos rázogatásra, ütögetésre a reakció indítása előtt.

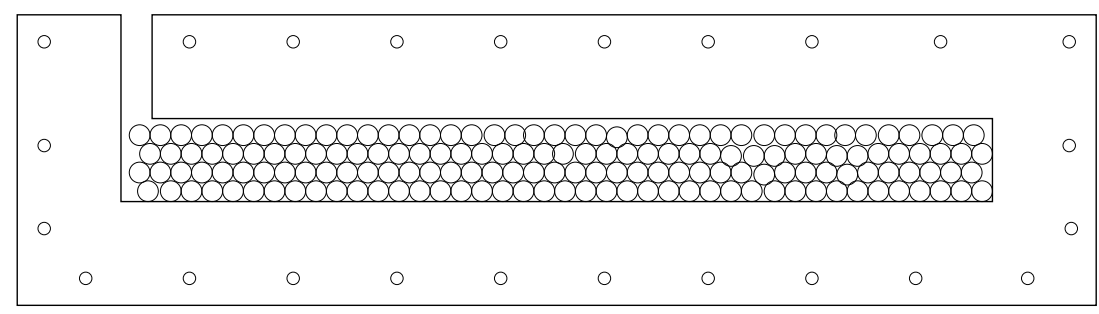

4.2. ábra. Hele-Shaw reakcióedény távtartójának sematikus, oldalnézeti képe a pórusos közeg kialakítására szolgáló boroszilikát gyöngyökkel.

\subsubsection{Az áramlási mezốt feltérképező rendszer}

A klorit-tetrationát autokatalitikus reakcióban kellôen nagy reakciótér alkalmazása esetén kialakuló háromdimenziós áramlási mezô meghatározásához a 4.3. ábrán látható kísérleti berendezést használtuk. A reakcióedény plexilapokból készült, kivéve a két végét, ahova fotólemezekből kivágott üveglapokat ragasztottunk. Ezek fontos tulajdonsága, hogy lapjaik teljesen párhuzamosak egymással, így a fény szóródása a nyaláb normális széttartásánál nagyobb mértékben nem volt megfigyelehetô az üveg felületen. Az edény által biztosított reakciótér $300 \mathrm{~mm}$ hosszú, $10 \mathrm{~mm}$ magas és $20 \mathrm{~mm}$ széles volt. Az alkalmazott lézer (Roithner LaserTechnik - CW532-100) 532 nm hullámhosszú zöld fényt bocsát ki, és kimeneti teljesítménye minimum 100 mW (összehasonlításként jegyzem meg, hogy egy hétköznapi lézermutató kimeneti teljesítménye körülbelül $10 \mathrm{~mW}$ ). A kibocsátott lézerfény útjába két gyứjtőlencsét helyeztünk, melyek közül a lézerhez közelebb eső egy hengerlencse volt (Techspec 69723). Ez a lencse a beeső fénynyalábot a lencse mögötti fókuszpont után egy széttartó síkká 


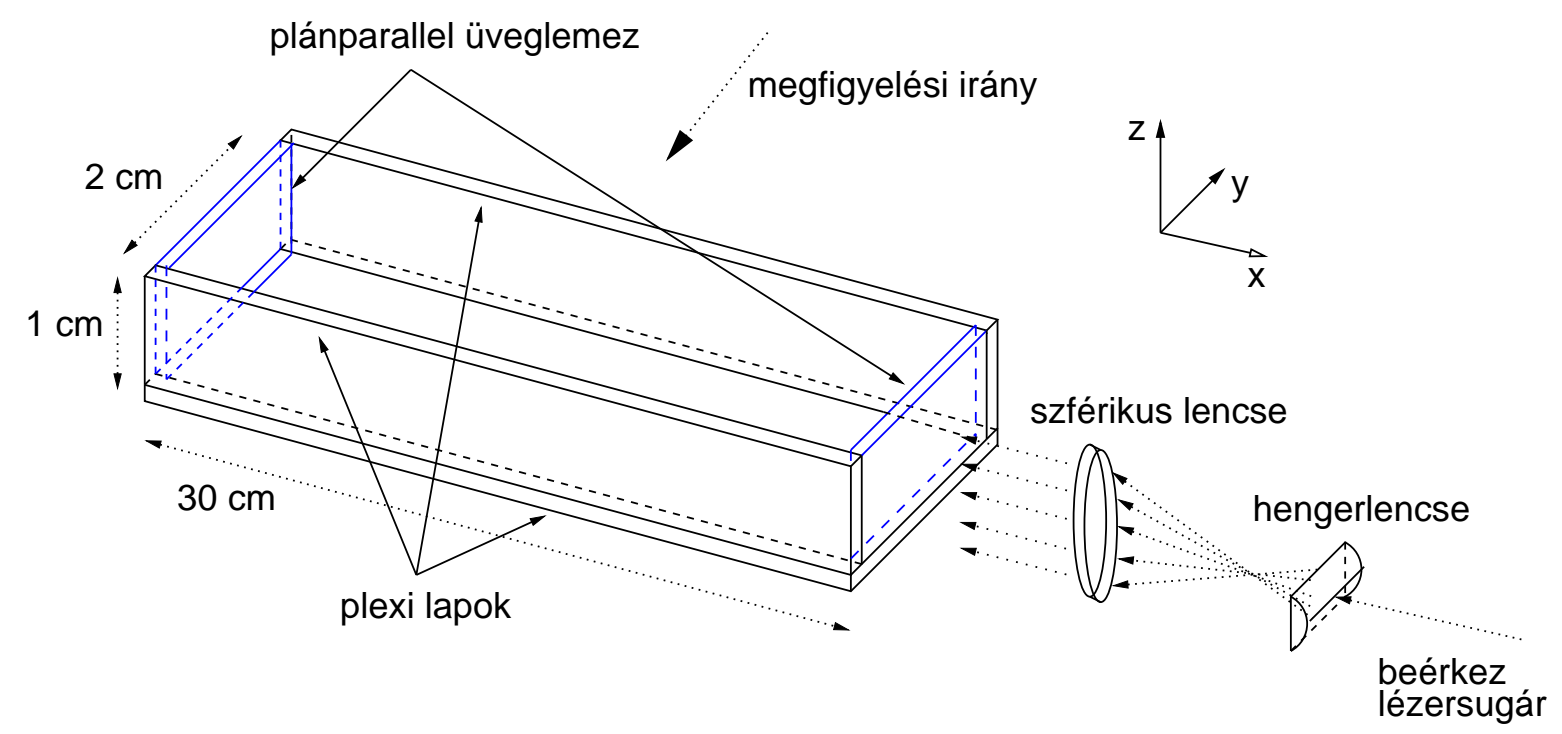

4.3. ábra. Részecske-képen alapuló sebesség-meghatározási módszer kísérleti elrendezése.

alakította. A második, szférikus lencsét (Techspec 47-357-INK), úgy helyeztük el, hogy fókuszpontja egybeessen az első lencse fókuszpontjával, így az elóbbi sugarak a lencse mögött párhuzamosítva haladtak tovább, mint ahogyan a lézerből való kilépéskor is párhuzamosak voltak, de most nem pontszerúen, hanem egy síkba rendezve. A reakcióedényt eltolható tálcára helyeztük, melyet 0,01 milliméter pontossággal tudtunk pozícionálni, így a lézer síkját mindig a kívánt helyen tudtuk keresztülbocsátani a folyadékrétegen. A reaktánsok $[\mathrm{NaOH}]=5 \mathrm{mM},\left[\mathrm{K}_{2} \mathrm{~S}_{4} \mathrm{O}_{6}\right]=5 \mathrm{mM},\left[\mathrm{NaClO}_{2}\right]=20 \mathrm{mM}$, [brómfenolkék] $=4,8 \cdot 10^{-3} \mathrm{mM}$ koncentrációban összekevert elegyéhez 6,4 $\mu \mathrm{m}$ átmérőjú latex gyöngyöket (Sigma-Aldrich MFCD00131491) adtunk körülbelül 0,01 tömegszázalékos koncentrációban, hogy a kiértekeléskor minden 32 · 32 képpont nagyságú területre körülbelül 20-30 darab részecske jusson. A homogenizált oldatot a reakcióedénybe öntöttuik és megvártuk, amíg a felszín hullámzása megszúnik. Ekkor az edény lézertôl távolabbi felén plexibe ágyazott U-alakú platina elektródpárt helyeztünk el, majd lefedtük a reakcióteret.

\subsection{A kísérlet kivitelezése}

A homogén közegú kísérleteket szobahőmérsékleten és $3{ }^{\circ} \mathrm{C}$-ra termosztálva is végrehajtottam. A temperált reakciók lejátszatásához a reaktánsoldatokat hútốben tároltam az összekeverés előttig, majd a homogenizált elegyet a reakcióedénybe töltöttem. Az állandó hômérséklet biztosítására egy hûtő-fútő termosztát (Heto HMT 200) állt rendelkezésre, melynek hútőköpenyei a reakciótér oldalához illeszthetők voltak. Mind a feltöltés előtt, mind a feltöltés után 15-15 percig hagytam a hőmérsékletet állandósulni, és csak ezután indítottam a 
reakciót.

A pórusos közeg alkalmazása esetén végzett kísérleteket időben a homogén közegú reakciók után hajtottam végre, így tudtam, hogy szükség van a hômérséklet állandó értéken tartására. Ezért minden esetben $3{ }^{\circ} \mathrm{C}$-ra történő termosztálást alkalmaztam az előzôekben leírt módon.

Az áramlási mező feltérképezésére irányuló vizsgálatokat szobahőmérsékleten végeztük, így az edény feltöltése és lezárása után a reakció inicializálásán kívül más teendőnk nem volt.

A kísérleteket mindhárom esetben platinaelektródokon $(0,25 \mathrm{~mm}$ átmérőjú szál) végzett elektrolízissel indítottuk. Ehhez az elektródokat tápegységhez kapcsoltuk (Power Supply 18135 / 18142), és 5 másodpercig elektrolizáltunk az elektródok között keltett 3 V feszültségkülönbséggel. Az anódon keletkező hidrogénion beindította a reakciót, melyet kamera (Sony DFW-X710 és Unibrain Fire-I620b) segítségével követtünk nyomon. A megfelelő kontrasztosság elérése érdekében kongóvörös indikátor esetén $548 \pm 8$ nm-en áteresztô, brómfenolkék esetén pedig $468 \pm 10$ nm-en áteresztő színszûrốt helyeztem a reakcióedény és a kamera közé. A 0,2-10 másodpercenként készített felvételeket számítógépre mentettük és a későbbiekben feldolgoztuk házilag készített kiértékelő programokat használva.

A reakció lejátszódása után a termékelegyet kiöntöttem, a Hele-Shaw edényeket szétszereltem és a vazelint izopropanollal lemostam. A reakcióedényeket mosogatószerrel megtisztítottam, csapvízzel, majd ioncserélt vízzel alaposan leöblítettem és végül a részeket szöszmentes kendővel szárazra töröltem. Az egy napon, pórusos közeg használata mellett végzett kísérleteknél elkoszolódott boroszilikát gyöngyöket éjszakára mosószeres vízben áztattam, másnap csapvízzel leöblítettem, és egy újabb éjszakát áztattam ioncserélt vízben. Ezután leszúrtem és hagytam kiszáradni ôket. A kísérleti eszközök tisztántartása elengedhetetlen alapfeltétele volt a precíz, reprodukálható méréseknek, hiszen a reakció autokatalitikus mivolta révén, az előző kísérlet termékeinek kicsiny mennyisége is spontán lejátszódást eredményezhetett volna. 


\section{5. fejezet}

\section{Kiértékelési módszerek}

\subsection{A frontprofil és a frontsebesség meghatározása}

A reakciófront helyének és alakjának meghatározásához a kamera által küldött digitális jeleket IEEE 1394-es porton keresztuil számítógépre vittük, majd egy 256 árnyalatú szürkeségi skálát használva a képpontokat besoroltuk. A skálán a 255 felelt meg a fehér, a 0 pedig a fekete színnek. Ezek alapján a korai kísérletekben, ahol indikátorként még kongóvöröset használtunk, a reaktánsoldat rendelkezett a piros színnek megfelelő nagyobb szürkeségi értékkel, míg a kékszínú termékoldatra ez az érték kisebb volt. Az indikátorváltásnál a szürkeségi viszonyok megfordultak, hiszen a lila színú reaktánsoldat szürkeségi értéke kisebb, mint a sárga színú termékoldaté.

A front pontos helyének megállapításához a csoportunkban készített kiértékelő program a front haladási irányában soronként megvizsgálta a képpontok szürkeségi értékét. Az így kapott függvény inflexiós pontja alapján a front adott pillanatbeli helyzete minden egyes képpontsorra megadható volt a hely szerinti első deriváltat kiszámítva. Ez az érték balról jobbra haladó frontok esetén a hely szerinti első derivált maximuma volt kongóvörös indikátornál, és a hely szerinti elsô derivált minimuma brómfenolkéket használva. Amint az 5.1. ábrán is látható, a pórusos közegben végzett kísérletek kiértékelésekor a gyöngyök jelenléte megnehezíti ezen inflexiós pont egyértelmú megtalálását, ezért ezekben az esetekben aluláteresztő szűrôt (Fourier-szűrô) is alkalmaztunk. A szưrő a gyöngyök méretéből adódó, kis hullámhosszú jeleket távolította el a spektrumból, így megkönnyítve a kiértékelést. Ezt a módszert használva minden sorban meghatároztuk a front pillanatnyi helyzetét, és így a reakció kétdimenziós profiljához jutottunk. A kiértékelés során az adott frontprofil helyzetét képpontban kaptuk meg, amit a kísérletek előtt elvégzett kalibráció segítségével cm-re tudtunk átalakítani, és így a különböző beállítások mellett kapott eredmények összehasonlíthatóvá váltak. Egy, az előbbiek alapján meghatározott frontprofil-sorozatot mutat be az 5.2. ábra, ahol pontozott vonallal a front indítását követôen kialakuló instabil alakzatot jelöltem, ami 
a reakcióedényben haladva fokozatosan stabilizálódik, majd állandó alakkal és sebességgel halad tovább.
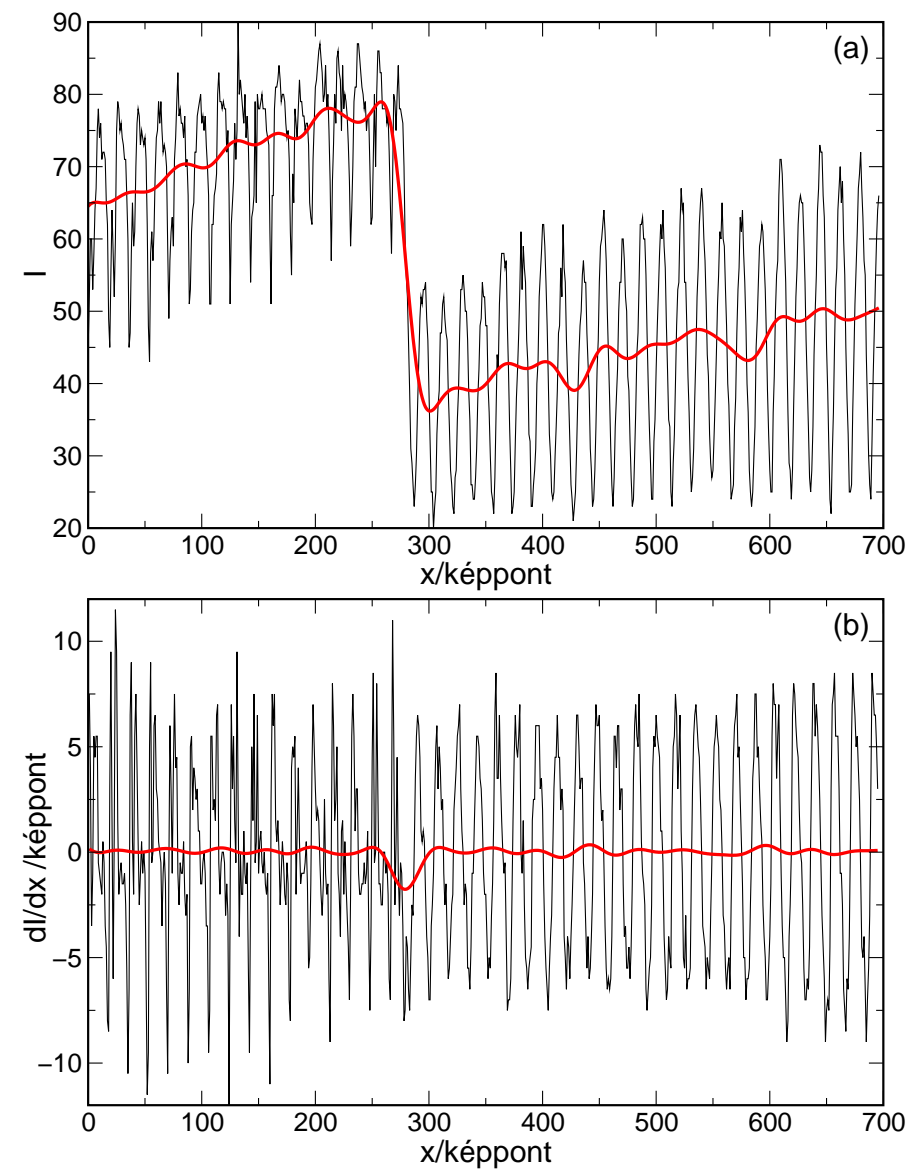

5.1. ábra. A szürkeségi értékek hely szerinti változás (a) és ezen függvény hely szerinti első deriváltja (b) pórusos közegben végzett reakció esetén. Fekete színnel az eredeti, piros színnel a Fourier-szúrố alkalmazása utáni jelet ábrázoltam.

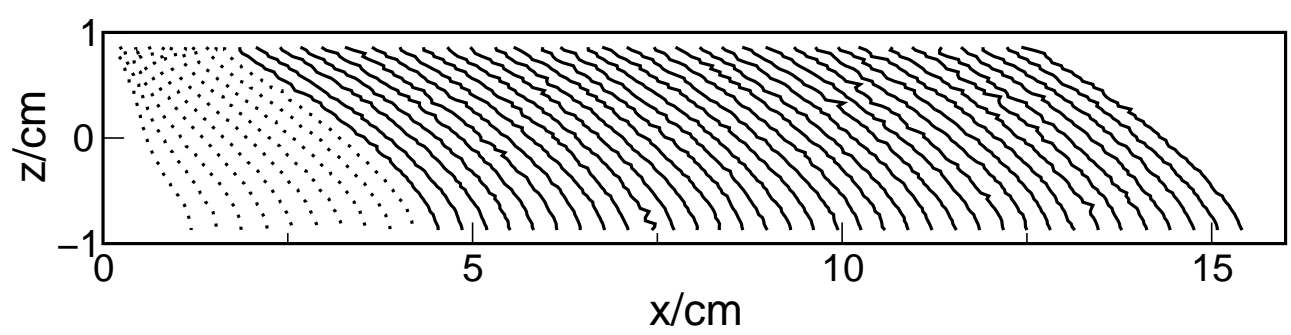

5.2. ábra. A reakciófront a Hele-Shaw edényben előre haladva az indítást követôen még instabil (pöttyözött vonal), majd idôvel állandósult alakkal (folytonos vonal) és sebességgel terjed tova. Kísérleti paraméterek: $\left[\mathrm{K}_{2} \mathrm{~S}_{4} \mathrm{O}_{6}\right]_{0}=3,75 \mathrm{mM},\left[\mathrm{NaClO}_{2}\right]_{0}=15 \mathrm{mM}$, $[\mathrm{NaOH}]_{0}=2,5 \mathrm{mM}, 2 \mathrm{~cm}$ edénymagasság, szobahőmérséklet. 


\subsection{A keveredési hossz és az átlagos frontalak definiálása}

A kísérletek során kialakuló reakciófrontok pontos összehasonlításához nem elég a front profiljának és sebességének ismerete, ezért vezettük be a keveredési hosszat $\left(\mathrm{L}_{\mathrm{m}}\right)$, mint a front jellemzésére szolgáló mennyiséget. Ennek meghatározásához kiszámoltuk az adott idôponthoz tartozó frontpozíciók átlagát, melyet átlagos frontpozíciónak $(\bar{x})$ neveztünk el. Az összes mérési pontot figyelembe véve a keveredési hossz ezen átlagos frontpozíciók szórásaként definiálható, amint azt az alábbi egyenlet is mutatja, hiszen hidrodinamikai mérésekben e mennyiség a két eltérô sûrûségú réteg keveredésének jellemzéséhez hasonlítható:

$$
L_{m}=\sqrt{\frac{\sum_{i=1}^{N}\left(x_{i}-\bar{x}\right)^{2}}{N-1}},
$$

ahol $N$ a frontot felépítô képpontok száma és $x_{i}$ az $i$-edik pontban a front helyzetét jelöli. A keverédi hossz ilyen módon történő számítása azért praktikus, mert a reakciófront minden pontjára kiterjed, és nem csak kettő (a legelőrehaladottabb és a leglemaradottabb) értéket vesz figyelembe. Az így meghatározott érték a front két végpontja között vizuálisan észlelhetô távolság negyede.

Amint az az előzőek alapján várható is, a keveredési hossz értéke a reakció indítását követően növekedik, hiszen a függőlegesen indított sík front elveszítve a stabilitását, a kísérleti körülményektől függő mértékben fokozatosan elnyúlik, mígnem kialakul az állandó alakzat, melyre állandó keveredési hossz jellemző. A frontnak az idő előrehaladtával történő stabilizálódását szemlélteti az 5.3. ábra, ahol a keveredési hosszat láthatjuk az idő függvényeként feltüntetve. A további kiértékeléskor csak az állandó keveredési hosszal rendelkező idôtartamot vizsgáltuk.

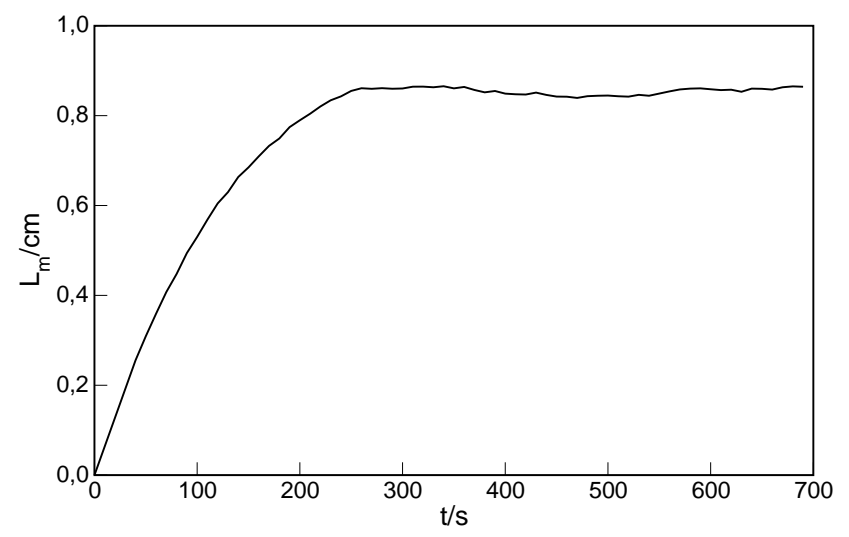

5.3. ábra. A frontalak stabilizálódása az idő függvényében. Kísérleti paramétereket lásd az 5.2. ábránál. 
A front mennyiségi leírására szolgáló számszerú jellemzés mellett meghatároztuk az állandó mintázat átlagos frontalakját is. Ehhez első lépésként a front időbeli előrehaladását küszöböltük ki minden egyes idôpontban az adott frontprofilból kivonva az átlagos frontpozíciót, majd a frontalakok átlagos helyét az $\mathrm{x}=0 \mathrm{~cm}$ koordinátához toltuk. A múvelet eredményét az 5.4. ábra mutatja be, ahol jól látszik, hogy az ábrázolt 45 görbe, melyek 10 másodpercenkénti képfelvétel mellett készültek, kísérleti hibán belül jól átfedik egymást, ami bizonyítja az alakzat hosszútávú állandóságát. Ezt követően a görbék azonos képpontsorba esô pontjait a front haladási irányával párhuzamosan átlagoltuk, és szórásukat is kiszámítottuk. Az így kapott átlagos frontalakot az 5.5. ábrán tüntettem fel.

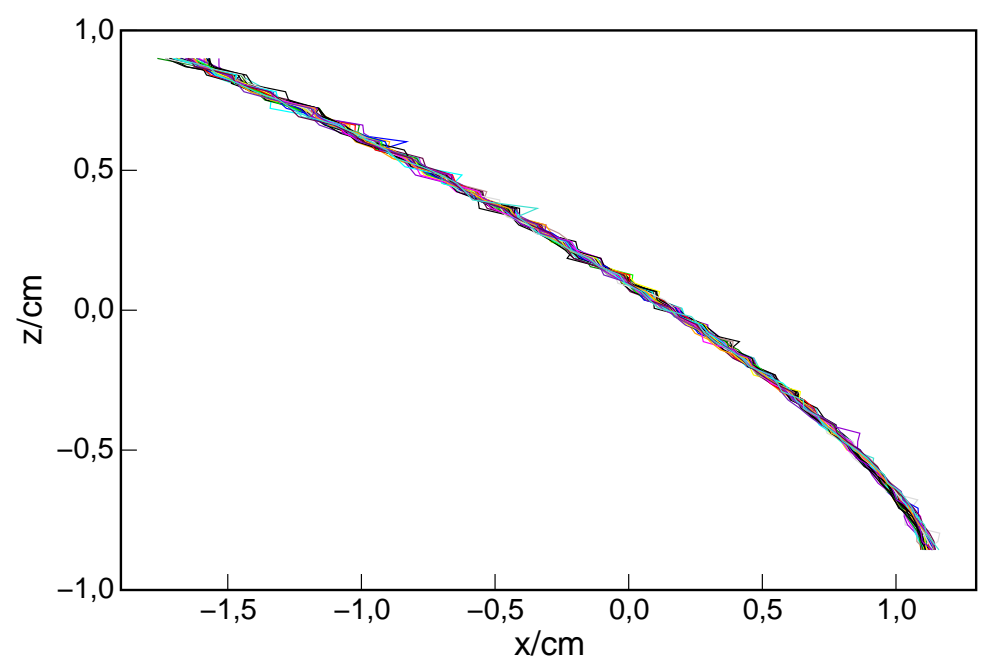

5.4. ábra. Az állandósult frontalak idôkülönbséggel korrigált, egymásra vetített alakja.

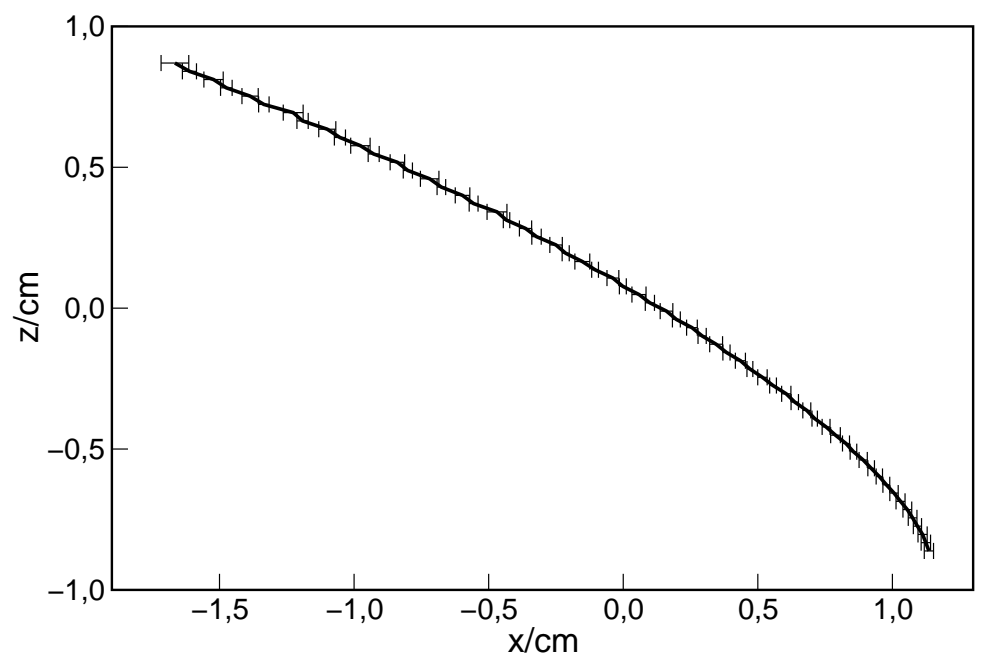

5.5. ábra. Az időben állandósult mintázatra jellemző átlagos frontalak, feltüntetve az alakzat pontjainak x tengely menti szórását. 


\subsection{A részecske-képen alapuló sebesség-meghatározás}

A kísérletek során 0,2 másodpercenként készített képekből a fényszóró részecskék elmozdulása alapján az áramlásra jellemző sebességi profil nyerhető ki. Az eredeti 1024 -768 képpont felbontású felvételt 64.64 képpont területű négyzetekre osztottuk fel, és ezen részterületekhez tartozott egy-egy átlagos elmozdulás. A kiértékelés folyamatát az 5.6. ábra segítségével mutatom be, ahol az egyszerúség kedvéért a vizsgált részterület csak egy fényszóró részecskét tartalmaz. A csoportunkban készített programmal megvizsgáltuk a képet, és minden ponthoz szürkeségi értéket rendeltünk a pont fényintenzitása alapján. Ha az adott képen lát-
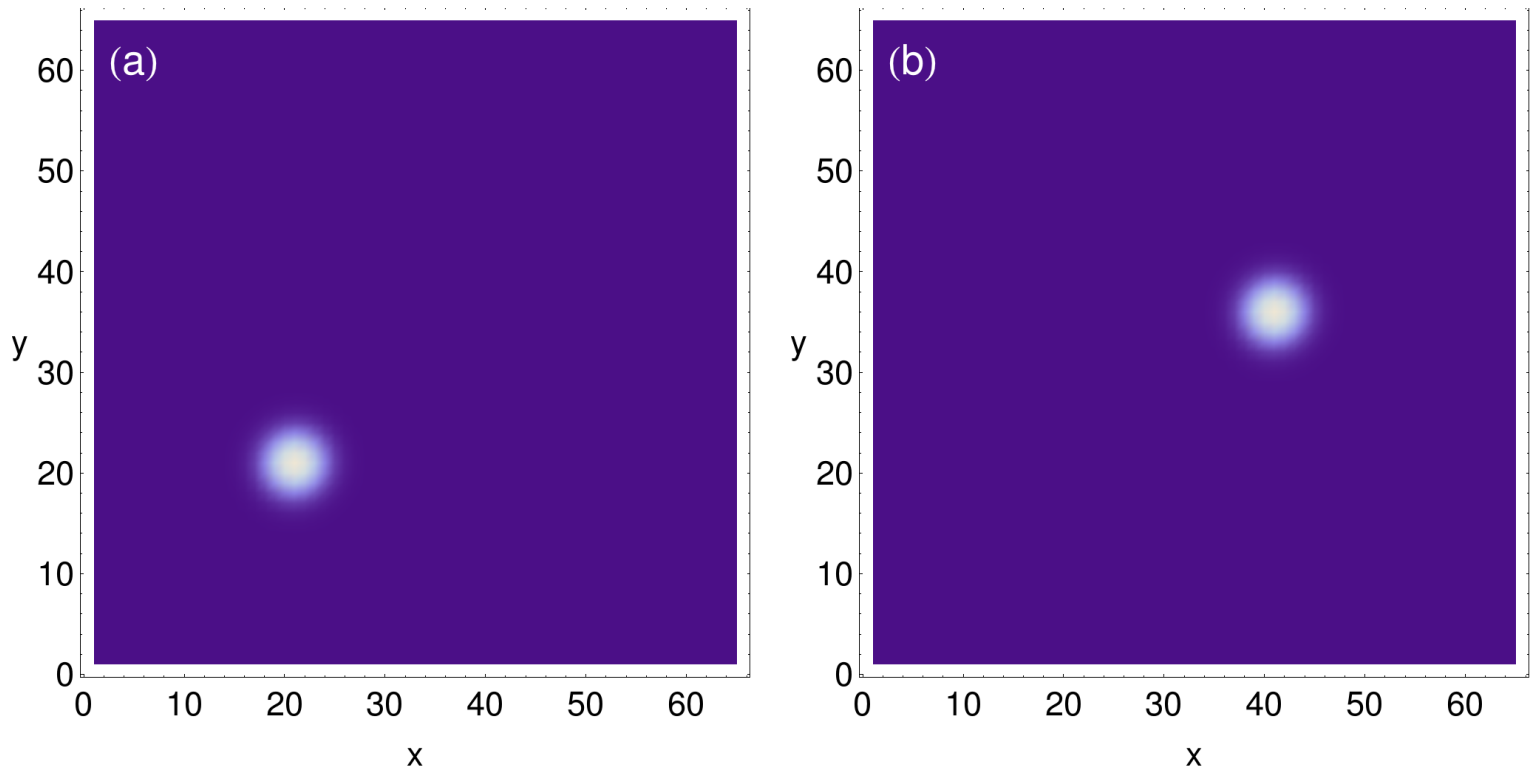

5.6. ábra. A fényszóró részecske (fehér folt a képen) mozgását szemléltetô, mesterségesen előállított részterület egy korábbi (a), és egy későbbi (b) időpontban.

ható pontokat egy valós értékú, kétdimenziós függvényként fogtuk fel, akkor kettô, idôben egymás utáni kép térbeli korrelációját gyors Fourier-transzformáció segítségével meg tudtuk határozni az alábbi tulajdonságot használva:

$$
C(f, g) \equiv f(m, n) \circ g(m, n) \Leftrightarrow F(\xi, \eta) G^{\star}(\xi, \eta)
$$

ahol a $g$ a $t$ idôpontban, a $f$ pedig a $t+d t$ idôpontban készített képet leíró függvényt, a $F$ a $f$ függvény Fourier-transzformáltját, és a $G^{\star}$ a $g$ függvény Fourier-transzformáltjának komplex konjugáltját jelenti. A továbbiakban a korrelációs függvény maximumának helyét kerestük, ami az átlagos elmozdulást adja meg. Az előbbi két képen látható részecske elmozdulását az 5.7. ábra alapján könnyedén meghatározhatjuk ( $x$ irányban 20, $y$ irányban 15 egység). A Fourier-transzformálás alkalmával a függvényeket periodikusnak tekintjük, emiatt a tényle- 
ges elmozdulás megadásához arra ügyelnünk kell, hogy amennyiben a számolt elmozdulás nagyobb, mint a vizsgált négyzet élhosszának a fele, akkor úgy kezeljük, mintha a részecske az elmozdulással ellentétes irányból érkezett volna.

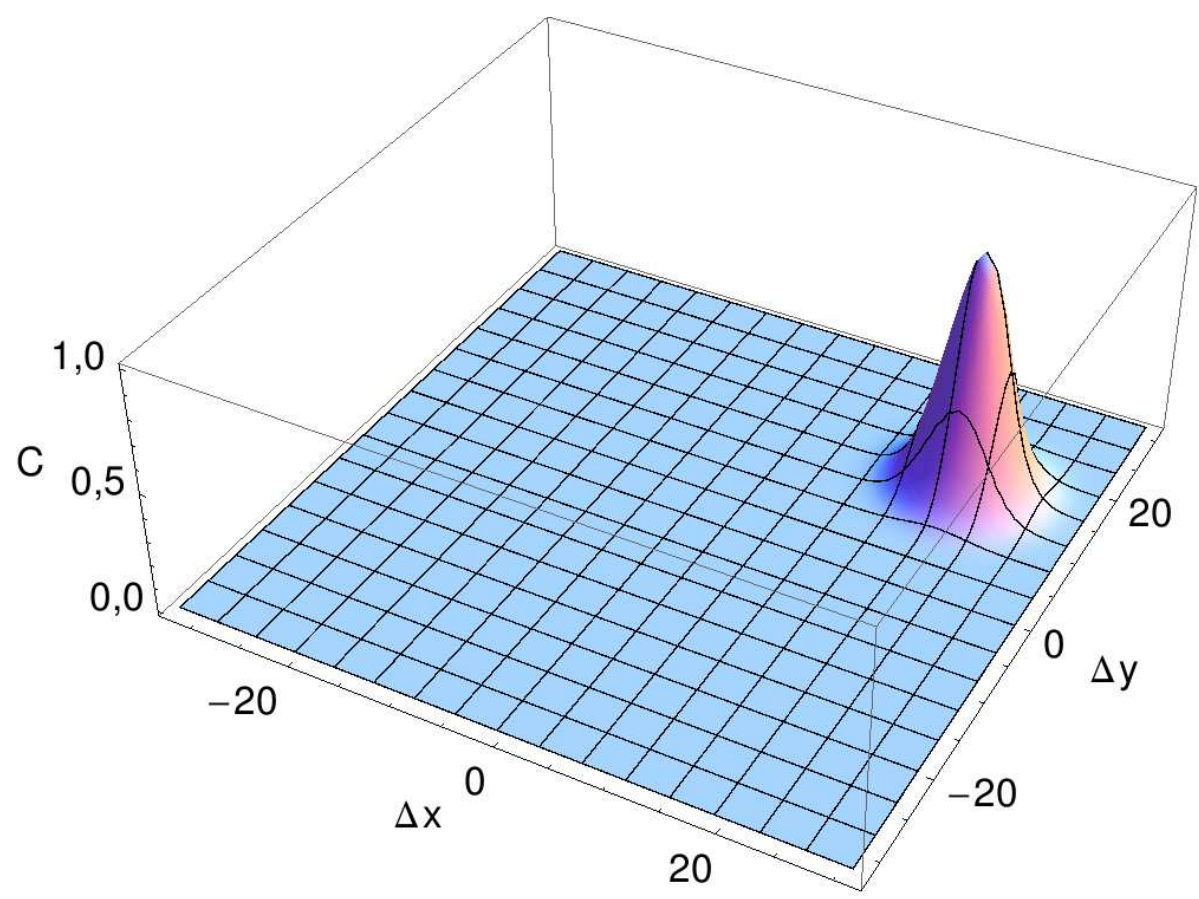

5.7. ábra. A korrelációs függvény maximuma határozza meg az elmodzulás vektorát az adott részterületben. A tengelyeken az $x$ és $y$ irányban történő elmozdulás $(\delta x, \delta y)$, és a korreláció mértéke $(C)$ látható.

Ezek alapján minden részterülethez hozzárendeltünk egy sebességvektort, ami megmutatta, hogy az adott mezőben a folyadék melyik irányba és mekkora sebességgel áramlik. Így feltérképezve az egész területet a térbeli reakciófrontnak egy függőleges, a reakció haladási irányával párhuzamos síkjára jellemző áramlási profilhoz jutottunk. Minden egyes profilt 5 darab képből állítottunk össze, hogy a teljes áramlási mezôt egyszerre láthassuk. A megfelelô felvételek kiválasztásához azt használtuk fel, hogy a kép vízszintes irányú felbontásának és a front terjedési sebességének ismeretében a két kép közötti időkülönbség számolható.

Ahhoz, hogy az egymástól $2 \mathrm{~mm}$ távolságban készült metszeteket a megfelelő módon illeszthessük egymás mellé, felülnézetből is lefényképeztük a frontot. Az oldalnézeti síkon a front legelőrehaladottabb pontjának egybe kell esnie a felülnézeti képen az adott síkhoz tartozó határral, amely a reaktáns és a termék között van. A metszeteket így egymás mellé tolva a reakció háromdimenziós áramlási profilját kaptuk. 


\section{6. fejezet}

\section{Eredmények}

\subsection{A hốmérséklet és a reakciótér méretének hatása}

A kísérleteket vízszintesen orientált reakcióedényben, szobahőmérsékleten végeztem el, függôleges frontot indítva. Kezdetben az alkalmazott távtartó $1 \mathrm{~mm}$ vastag volt, magasságát pedig 1,$0 ; 1,5 ; 2,0 ; 2,5 ; 3,0$; és 4,0 cm között tudtam változtatni. A klorit-tetrationát rendszerben izoterm körülmények között a termékoldat sûrúsége kis mértékben, de nagyobb, mint a reaktánsoldaté $\left(25{ }^{\circ} \mathrm{C}\right.$-on $0,0003 \mathrm{~g} \mathrm{~cm}^{-3}$ a különbség $\left[\mathrm{K}_{2} \mathrm{~S}_{4} \mathrm{O}_{6}\right]_{0}=5,00 \mathrm{mM}$ és $\left[\mathrm{NaClO}_{2}\right]_{0}=20 \mathrm{mM}$ kiindulási koncentrációt alkalmazva [85]), így a kezdetben függőleges reakciófront elveszíti a stabilitását. Miközben a reakció frontszerúen halad végig az edényben, a termékoldat elkezd süllyedni, kiszorítva a reaktánsoldatot az alsó térrészből, amely így konvekciót indukálva felfelé áramlik. A front a kísérleti paraméterektôl függően egy adott idô eltelte után stabilizálódik, és állandó alakkal és sebességgel terjed tovább. Ilyen állandó alakzatokról készült felvételek láthatók a 6.1. ábrán, ahol a sötétebb színnel a termékoldat, világosabb színnel pedig a reaktánsoldat rendelkezik. Jól látszik, hogy ha egy adott edényvastagság esetén a reakciótér magasságát növeljük, akkor az alakzat egyre elnyúltabbá válik, ami a rá jellemző keveredési hossz növekedésében nyilvánul meg. A kísérleteket az említett nagyságú távtartókat alkalmazva három különbözô kiindulási koncentrációval játszattam le, melyeket a 4.1. táblázatban tüntettem fel. A reakciók kiértékelésekor eredményként kapott keveredési hossz értékeket az edény magasságának a függvényében tüntettem fel a 6.2. ábrán, mindhárom koncentráció esetén. A mérési pontokra hatványfüggvényt illesztettem a Mathematica programcsomag segítségével, és meghatároztam az illesztett görbék együtthatóit és hatványkitevőit.

A legkisebb reaktánskoncentráció esetén a függvény egyenlete

$$
L_{m} / \mathrm{cm}=(0,37 \pm 0,02)\left(L_{z} / \mathrm{cm}\right)^{1,20 \pm 0,05}
$$




\section{(a)}
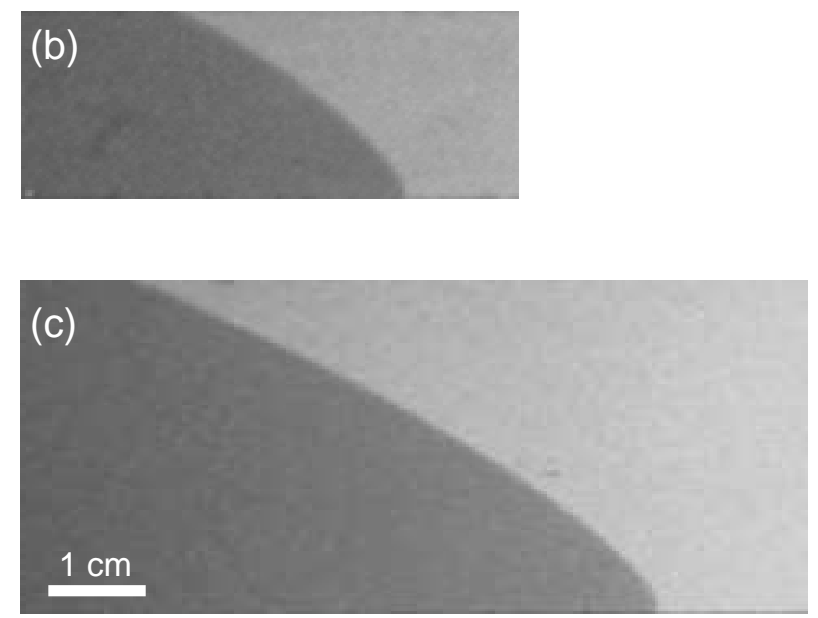

6.1. ábra. Vízszintesen haladó állandósult alakzat $1 \mathrm{~mm}$ vastag, (a) $1 \mathrm{~cm}$, (b) $2 \mathrm{~cm}$, és (c) $4 \mathrm{~cm}$ magas reakcióedényben. Az alkalmazott koncentrációk a reaktánselegyben: $\left[\mathrm{K}_{2} \mathrm{~S}_{4} \mathrm{O}_{6}\right]_{0}=5,00 \mathrm{mM},\left[\mathrm{NaClO}_{2}\right]_{0}=20 \mathrm{mM},[\mathrm{NaOH}]_{0}=2,5 \mathrm{mM},[\text { kongóvörös }]_{0}=0,057 \mathrm{mM}$. Sötétebb színnel a termékoldat, világosabbal a reaktánsoldat látható.

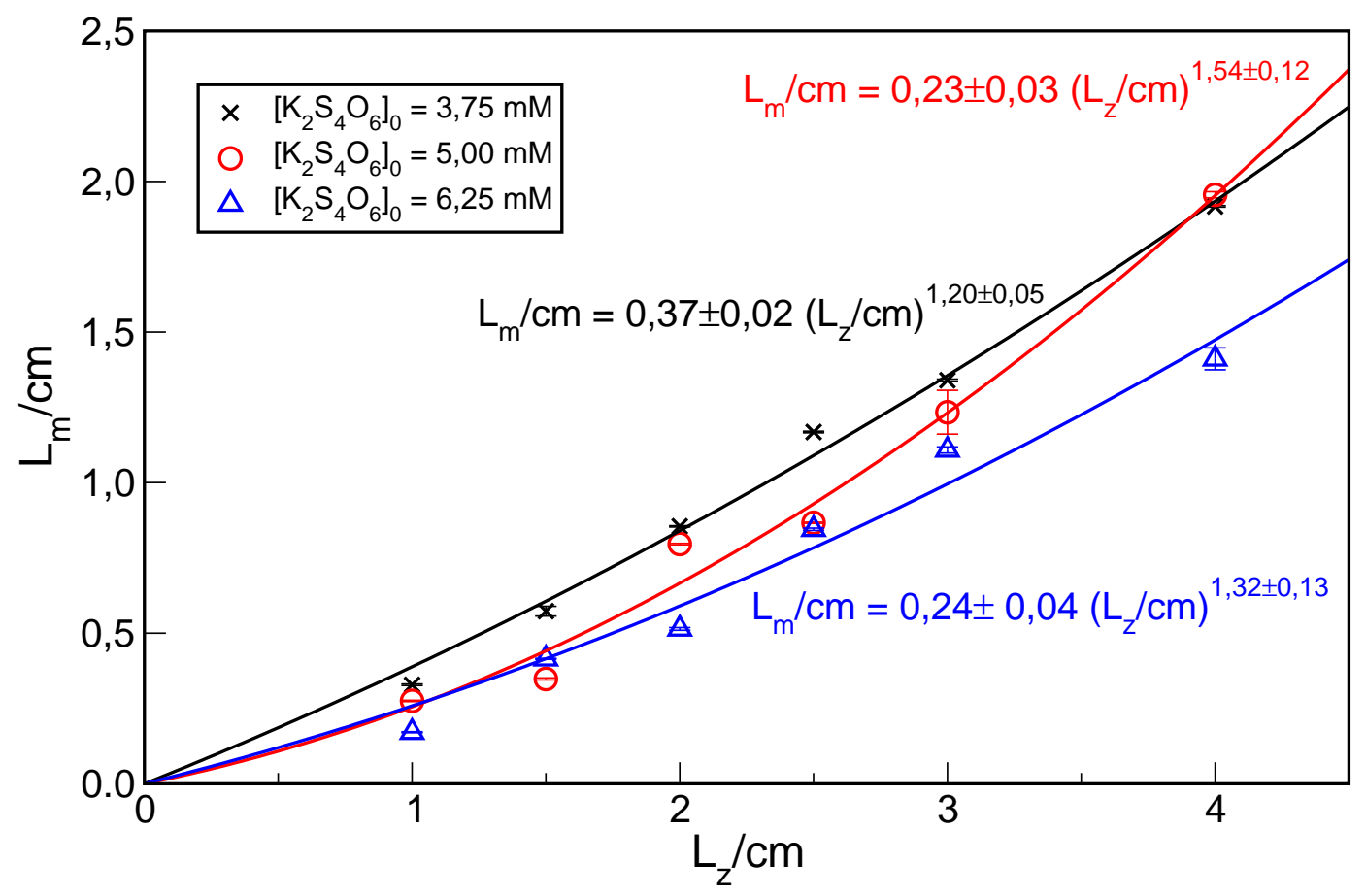

6.2. ábra. A keveredési hossz értékek az edénymagasság függvényében három különböző kiindulási koncentrációt használva, $25{ }^{\circ} \mathrm{C}$-on végrehajtott kísérletek esetén. A folytonos vonalak a hatványfüggvény-illesztés eredményét mutatják. 
alakúnak adódott. A kezdeti koncentrációkat a $\left[\mathrm{K}_{2} \mathrm{~S}_{4} \mathrm{O}_{6}\right]_{0}=5,00 \mathrm{mM}$-nak megfeleló értékre növelve a három görbe közül a legmeredekebben növekvő egyenletét kaptuk

$$
L_{m} / \mathrm{cm}=(0,23 \pm 0,03)\left(L_{z} / \mathrm{cm}\right)^{1,54 \pm 0,12}
$$

melyet az ábrán piros színnel jelöltem. A legnagyobb koncentrációjú összetétel esetén kaptam a legkisebb keveredési hossz értékeket, ahol a pontokra illesztett függvény az

$$
L_{m} / \mathrm{cm}=(0,24 \pm 0,04)\left(L_{z} / \mathrm{cm}\right)^{1,32 \pm 0,13}
$$

alakban adható meg. Mindhárom egyenletben jól látszik, hogy a hatványkitevő szignifikánsan eltér az elméleti úton jósolt négyzetes arányosságtól. Az illesztett egyenletek jóságának megállapításához a különböző edénymagasságok esetén kialakuló állandó alakzatra jellemző profilokat átskáláztuk az egyenletekben szereplő kitevőket használva. Ehhez a front haladási irányára merőleges $z$-koordinátát az aktuális edénymagassággal $\left(\eta=z / L_{z}\right)$, a haladási irányba esô $x$-koordinátát pedig az edénymagasság megfelelő hatványával $\left(\xi=x / L_{z}^{1,3}\right)$ osztottuk el. Amint a 6.3. ábráról is kitûnik, a hat különböző kísérleti összeállítás mellett kialakult stabil frontalak átskálázott formája kísérleti hibán belül egybeesik, tehát az általunk meghatározott egyenletek az adott körülmények között jól leírják az alakzatok edénymagasságtól való függését.

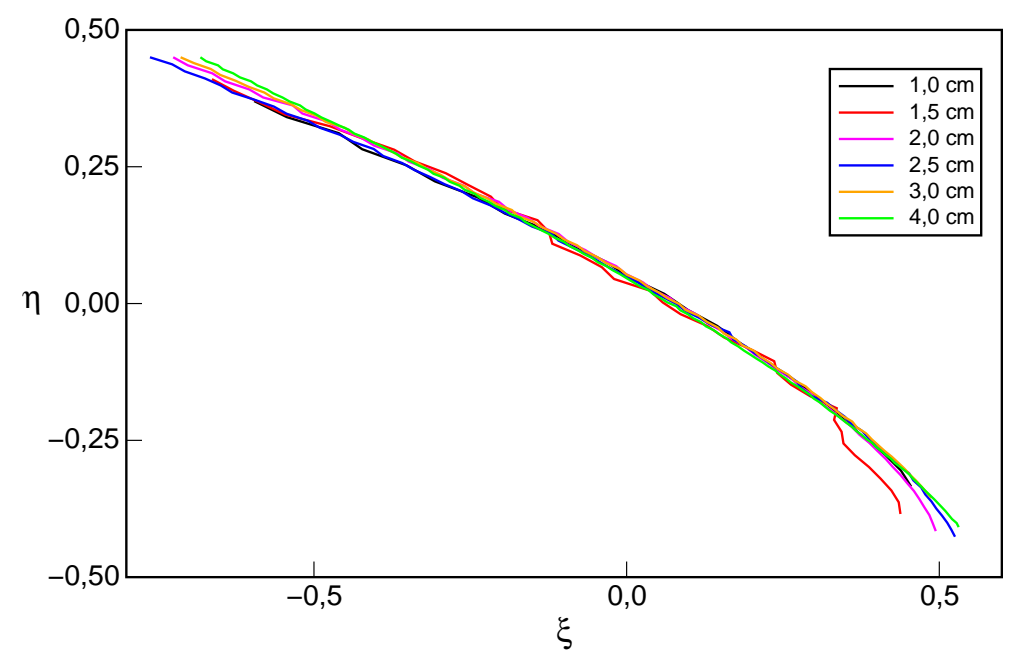

6.3. ábra. Az $1 \mathrm{~mm}$ széles, és különböző magasságú távtartókkal lejátszatott reakciók esetén kapott átskálázott végső frontalakok. Az alkalmazott koncentrációk a reaktánselegyben: $\left[\mathrm{K}_{2} \mathrm{~S}_{4} \mathrm{O}_{6}\right]_{0}=3,75 \mathrm{mM},\left[\mathrm{NaClO}_{2}\right]_{0}=15 \mathrm{mM},[\mathrm{NaOH}]_{0}=2,5 \mathrm{mM}$.

A mintázatok kialakulásában fontos szerepe van a reaktánsok kiindulási koncentrációjának, hiszen ha állandó nátrium-hidroxid koncentráció mellett nő a kálium-tetrationát és a nátrium-klorit koncentrációja, akkor nô a sûrúségküilönbség a termékek és a reaktánsok 
között [86], ez pedig a konvekció felerősödését vonja maga után. Minél erősebb a konvekció okozta közegmozgás, annál nagyobb a front alakjának elnyúlását mutató keveredési hossz értéke is. Ennek ellenére a 6.2. ábra adatai azt mutatják, hogy a koncentráció növekedése a keveredési hossz csökkenésével jár együtt. Úgy gondoltuk, hogy ez a viselkedés a reakció lejátszódása során a front helyén bekövetkező hőmérsékletváltozással lehet kapcsolatban még $1 \mathrm{~mm}$ folyadékvastagság esetén is. A klorit-tetrationát reakció erôsen exoterm $\left(\Delta_{r} H=-3960 \pm 50 \mathrm{~kJ} / \mathrm{mol}\right)$, ami azt jelenti számunkra, hogy a reakciófront közelében hô szabadul fel, amely az oldat sûrúségcsökkenését eredményezi, vagyis a hatása pontosan ellentétes irányú az izoterm körülmények között mért összetételváltozás által okozott sûrúségváltozással. Ennek a gondolatmenetnek az igazolásához a reakció során felszabaduló hő hatásának eliminálása volt szükséges a továbbiakban.

A kísérleteket híg vizes oldatokat használva hajtottam végre, ezért olyan hômérséklet kiválasztása volt a cél, ahol a víz sủrúsége a lehetô legkevésbé változik a hőmérséklet változásával. Megvizsgálva a víz sûrúségének hőmérsékletfüggését (lásd a 6.4. ábra) a $3{ }^{\circ} \mathrm{C}$-ra történô termosztálás mutatkozott a leginkább célszerú választásnak, hiszen a görbe $3-5{ }^{\circ} \mathrm{C}$ között maximummal rendelkezik, vagyis a front közelében bekövetkező 1-2 ${ }^{\circ} \mathrm{C}$-os hômérsékletnövekedés által okozott sûrúségváltozás itt a legkisebb.

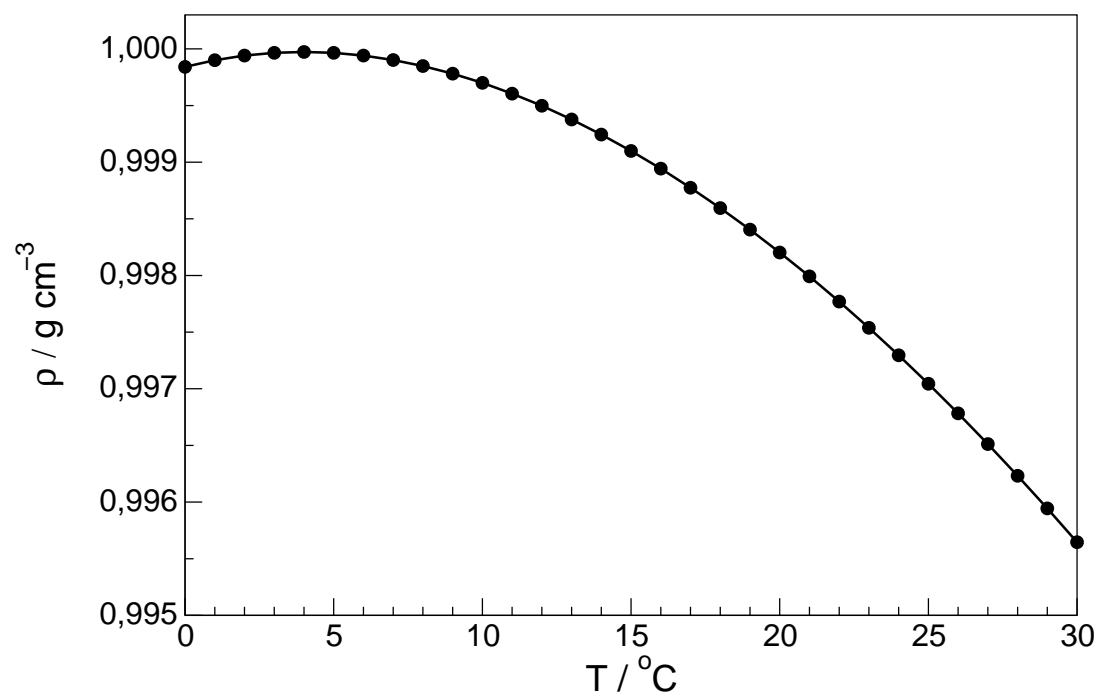

6.4. ábra. A víz sûrúségének hőmérsékletfüggése.

A fentiek alapján tehát a kísérleteket a korábban leírt távtartókat használva ismét elvégeztem mindhárom koncentráció esetén, de most $3{ }^{\circ} \mathrm{C}$-ra termosztálva. A reakciók során kialakult állandó alakzatok mindegyikére meghatároztam a keveredési hossz értékeket, és ezeket ismét az edénymagasság függvényében ábrázoltam, amint azt a 6.5. ábra be is mutatja. 


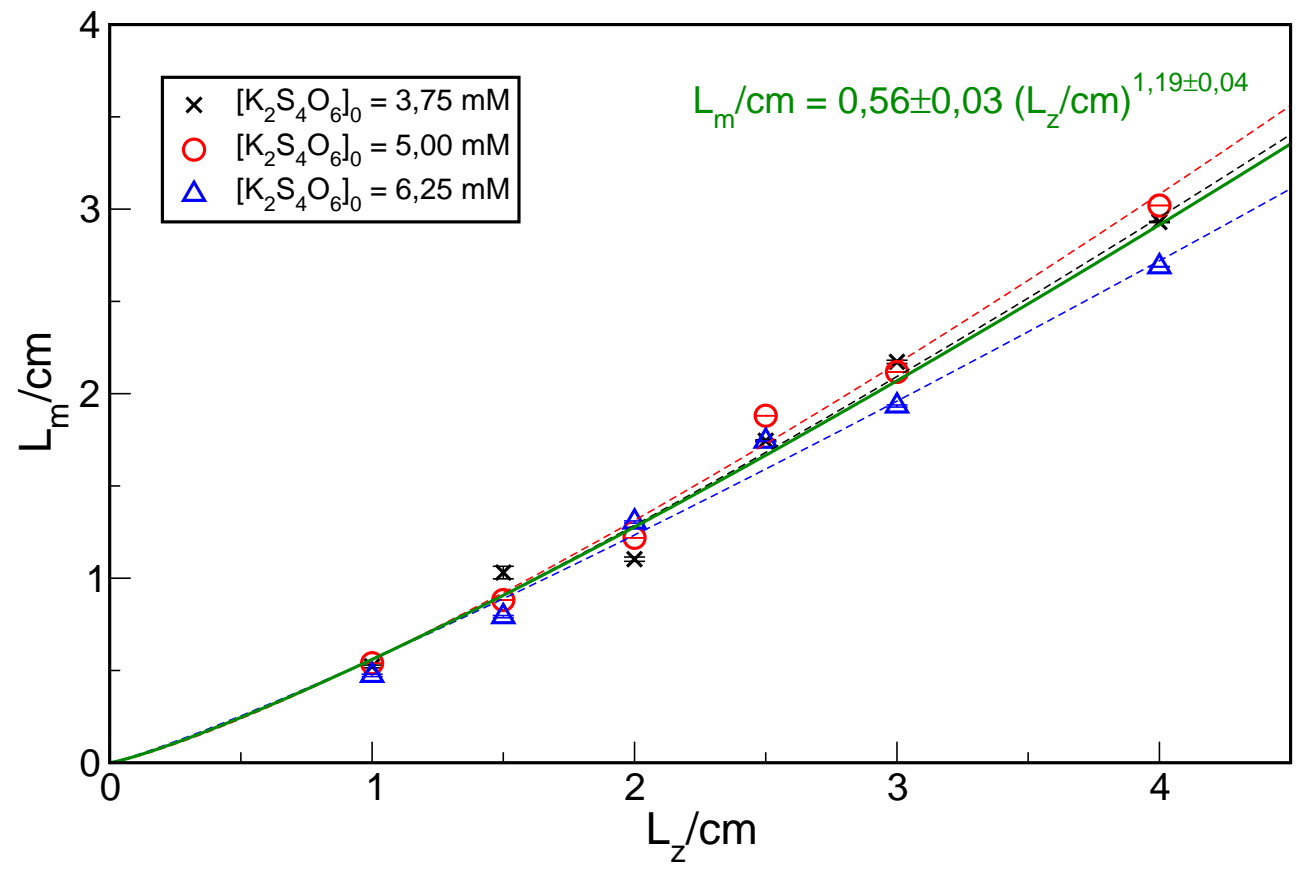

6.5. ábra. A keveredési hossz értékek az edénymagasság függvényében három különböző kiindulási koncentrációt használva, $3{ }^{\circ} \mathrm{C}$-on végrehajtott kísérletek esetén. A szaggatott vonal az egyenkénti illesztés, a folytonos vonal pedig az összes mérési pontra végrehajtott közös illesztés eredményét mutatja.

A kapott pontokra ismét hatványfüggvényt illesztettem, és meghatároztam a görbéket leíró egyenleteket is, amely a legkisebb koncentráció esetén

$$
L_{m} / \mathrm{cm}=(0,56 \pm 0,06)\left(L_{z} / \mathrm{cm}\right)^{1,20 \pm 0,09}
$$

alakban írható fel. A kiindulási koncentrációt $\left[\mathrm{K}_{2} \mathrm{~S}_{4} \mathrm{O}_{6}\right]_{0}=5,00 \mathrm{mM}$-nak megfelelő összetételre növelve a következő egyenlethez jutottunk:

$$
L_{m} / \mathrm{cm}=(0,56 \pm 0,05)\left(L_{z} / \mathrm{cm}\right)^{1,23 \pm 0,07}
$$

míg a legnagyobb koncentrációval végrehajtott kísérletekre

$$
L_{m} / \mathrm{cm}=(0,56 \pm 0,05)\left(L_{z} / \mathrm{cm}\right)^{1,14 \pm 0,08}
$$

eredmény adódott. A felírt egyenletekből kitűnik, hogy mind az arányossági tényezők, mind a hatványkitevő́k kísérleti hibán belül megegyeznek, ezért elvégezhető egy olyan illesztés is, ahol az összes pontra együtt illesztünk hatványfüggvényt. Ennek az illesztésnek az eredmé- 
nyét mutatja a zöld folytonos vonal a 6.5. ábrán, melynek az egyenlete

$$
L_{m} / \mathrm{cm}=(0,56 \pm 0,03)\left(L_{z} / \mathrm{cm}\right)^{1,19 \pm 0,04}
$$

alakúnak adódott, ahol a hatványkitevő jelentősen különbözik az elméleti számításokban kapott négyzetes összefüggéstől.

A továbbiakban kísérleteket végeztünk azonos kémiai összetétel mellett szobahőmérsékleten, különböző vastagságú távtartókat felhasználva. A reakció során létrejövő alakzatok a 6.6 . ábrán láthatók. Az 1 és $2 \mathrm{~mm}$ vastag reakciótér esetén kialakult stabil mintázatok (6.6 . ábra (a-b) fénykép) lényegileg hasonlítottak egymáshoz, a folyadékréteg vastagságának kétszeresére növelése nem mutatkozott meg számottevő változásban a front alakját illetően. Ezzel szemben $3 \mathrm{~mm}$ vastag távtartó esetén (6.6 . ábra (c) fénykép) a front eddigi viselkedése jelentősen megváltozott, ami ismét a hőmérséklet hatására vezethetô vissza. A folyadékréteg vastagságát növelve nő a front adott helyén felszabaduló hő mennyisége, és romlik a falon keresztüli hőelvonás hatékonysága, ami növekvő mértékű sűrűségcsökkenéshez vezet a termékoldatban. Elegendően széles reakcióedényben a reaktánsok és a termékek

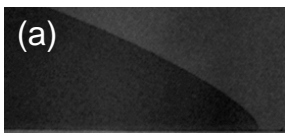

(b)

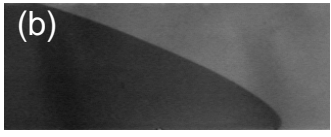

(c)

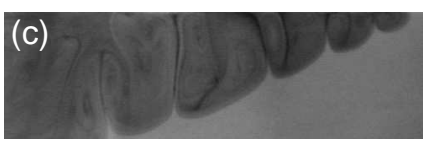

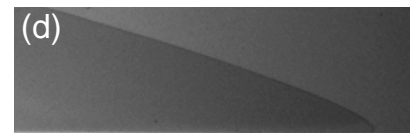

(e)

$(\mathrm{f})$

6.6. ábra. Az 1; 2; és $3 \mathrm{~mm}$ széles és $4 \mathrm{~cm}$ magas távtartó esetén, szobahőmérsékleten (a; b; és c) és $3{ }^{\circ} \mathrm{C}$-on (d; e; és f) végrehajtott kísérletekben kialakuló mintázatok. Az alkalmazott koncentrációk a reaktánselegyben: $\left[\mathrm{K}_{2} \mathrm{~S}_{4} \mathrm{O}_{6}\right]_{0}=5,00 \mathrm{mM},\left[\mathrm{NaClO}_{2}\right]_{0}=20 \mathrm{mM}$, $[\mathrm{NaOH}]_{0}=2,5 \mathrm{mM}$, [kongóvörös $]_{0}=0,057 \mathrm{mM}$. Sötétebb színnel a termékoldat, világosabbal a reaktánsoldat látható.

között izotermikus esetben fennálló sưrúségkülönbség előjele megfordul a hőmérséklet növekedése miatt, és a termékoldat könnyebbé válva a reaktánsoldatnál, felül helyezkedik el. A front továbbhaladása miatt azonban a hőmérséklet fokozatosan csökken, ismét a termék sûrúsége lesz a nagyobb, ezért süllyedni kezd, kiszorítva a reaktánsoldatot, és ezzel ismét konvekciót indukál. Az alakzatot létrehozó gyưrúk helye nem változik, csak a méretük nô a front távolodásával. Ennek a viselkedésnek a következményeként kialakuló instabil, aszimmetrikus mintázatot mennyiségileg nem tudtuk jellemezni, de azt megfigyeltük, hogy a rés 
magasságának a növelésével az alakzat formája megmaradt, amplitúdója pedig többszörösére nőtt.

Annak bizonyítására, hogy az előbbiekben leírt instabil mintázat kialakulásának oka valóban a reakcióban felszabaduló hő, a kísérleteket elvégeztük $3{ }^{\circ} \mathrm{C}$-ra termosztálva is mindhárom edényvastagság és minden lehetséges edénymagasság esetén. Ezen kísérletekhez tartozó stabil frontalakok képei közül mutat be néhányat a 6.6. ábra (d-f). Szabad szemmel is jól látszik, hogy a termosztálás hatására mindhárom edényvastagság esetén a szobahômérsékeleten 1 és $2 \mathrm{~mm}$ vastag távtartó alkalmazásakor is tapasztalható alakzat jött létre. Ezek alapján elmondható, hogy valóban a reakcióban bekövetkező hőmérsékletnövekedés hatására kialakuló sưrúségcsökkenés okozta szobahőmérsékleten, 3 mm-es távtartót használva az instabil, asszimetrikus alakzatot. Az is egyértelmúen megállapítható, hogy azonos távtartó esetén a szobahőmérsékleten végzett kísérletekben kialakult front kevésbé elnyúlt, mint a $3{ }^{\circ} \mathrm{C}$-ra termosztált reakciókban. A keveredési hossz növekedése figyelhetô meg a temperált reakciókban is a reakciótér vastagságának növelésével (6.6. (d-f) ábra). A mennyiségi jellemzéshez a $\left[\mathrm{K}_{2} \mathrm{~S}_{4} \mathrm{O}_{6}\right]_{0}=5,00 \mathrm{mM}$-os összetételnek megfelelően elvégzett reakciókban meghatározott keveredési hossz értékeket az edénymagasság függvényében ábrázoltam, ahogyan ezt a 6.7. ábra is szemlélteti. A kísérleti adatokra ismét hatványfüggvényt illesztettem, és meghatároztam a görbéket leíró egyenleteket. Az $1 \mathrm{~mm}$-es távtartóval végrehajtott reakciókban kialakuló mintázatok a

$$
L_{m} / \mathrm{cm}=(0,56 \pm 0,03)\left(L_{z} / \mathrm{cm}\right)^{1,19 \pm 0,04}
$$

egyenlettel írhatók le (ez megegyezik a (6.7) egyenlettel, itt csak a könnyebb áttekinthetőség érdekében tüntettem fel újra). Növelve az edényvastagságot az elóbbi egyenlet

$$
L_{m} / \mathrm{cm}=(0,99 \pm 0,10)\left(L_{z} / \mathrm{cm}\right)^{1,34 \pm 0,09}
$$

alakúra változik, míg 3 mm-es távtartó esetén a

$$
L_{m} / \mathrm{cm}=(1,32 \pm 0,13)\left(L_{z} / \mathrm{cm}\right)^{1,31 \pm 0,08}
$$

egyenlőség lesz igaz. Az előbbiek alapján elmondható, hogy az illesztett görbék egyenleteiben a kitevők kísérleti hibán belül megegyeznek, az együtthatók pedig az edényvastagsággal együtt növekednek. A kísérleti eredmények arra engednek következtetni, hogy bár $3{ }^{\circ} \mathrm{C}$-on a reakciófront alakja független a reaktánsok koncentrációjától (6.5. ábra), nagymértékben függ a reakciótér paramétereitől (6.7. ábra). 


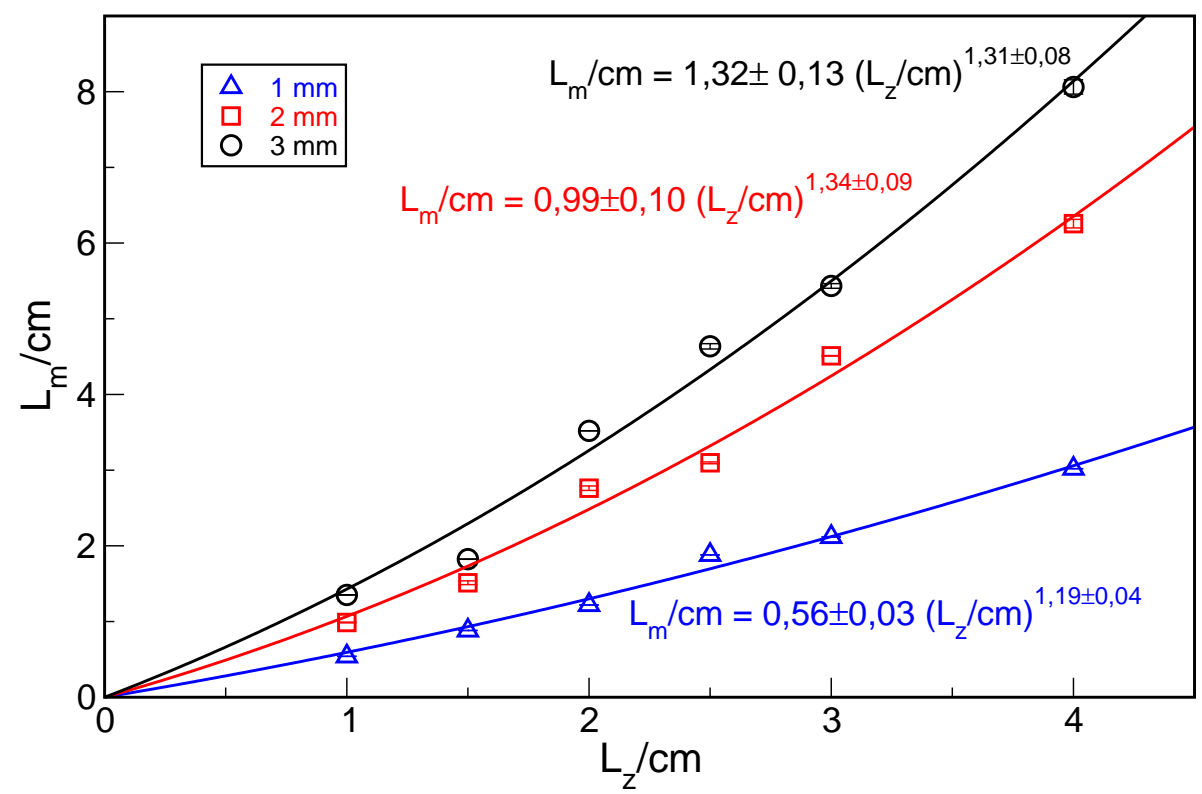

6.7. ábra. A keveredési hossz értékek az edénymagasság függvényében három különbözó edényvastagság esetén, $3{ }^{\circ} \mathrm{C}$-ra termosztált kísérletekben. A folytonos vonalak a hatványfüggvény-illesztés eredményét mutatják.

\subsection{A pórusos közeg jellemzése}

Kísérleteim során a pórusos közegnek a reakció közben kialakuló konvekcióra, illetve a létrejövő mintázatra gyakorolt hatását is vizsgáltam, így a tapasztalatok korrekt elemzéséhez elengedhetetlen a pórusos közeg tulajdonságainak meghatározása. A folyadékok áramlása szempontjából a rendszer porozitása és permeabilitása az a jellemző, amely jelen körülmények között befolyással lehet a reakciófront alakjára, sebességére. Meg kell jegyezni, hogy a talajban, illetve egyéb rendszerekben, ahol a pórusok száma nagy, de méretük kicsiny, fontos szerepet játszik a perkoláció folyamata, ám az alkalmazott kísérleti körümények között a perkolációs határ felett vagyunk, azaz a gyöngyök közötti térrész összefüggő csatornarendszert alkot, így az átszivárgás mértékének meghatározásával nem foglalkoztam.

\subsubsection{A porozitás meghatározása}

Első lépésként a közeg porozitásának meghatározása volt a célom, melyhez az

$$
\varepsilon=\frac{\text { szabad térfogat }}{\text { összes térfogat }}
$$

összefüggés használható. A különböző kísérletekben eltérô, de egy adott kísérletben azonos méretû́ gyöngyöket alkalmaztam a pórusos közeg kialakításához, ezért a porozitást általános esetre határoztam meg. A gyöngyöket a lehető legszorosabb illeszkedést biztosító hexago- 
nális módon helyeztem el, először egy rétegben, amint a 6.8. ábrán is látható. Az elméleti szabad térfogat meghatározható az ábrán feltüntett szabályos háromszög alapú hasáb segítségével. A hasáb térfogatát az alaplap területének ( $2 r$ oldalú szabályos háromszög esetén $\left.T=\sqrt{3} r^{2}\right)$ és a hasáb magasságának ( $\left.2 r\right)$ szorzataként kapjuk, azaz $V_{\text {hasáb }}=2 r T=2 \sqrt{3} r^{3}$. A gyöngyök térfogatát jól közelítjuik, ha szabályos gömbnek tekintjük őket, tehát $V_{\text {gyöngy }}=\frac{4}{3} r^{3} \pi$.

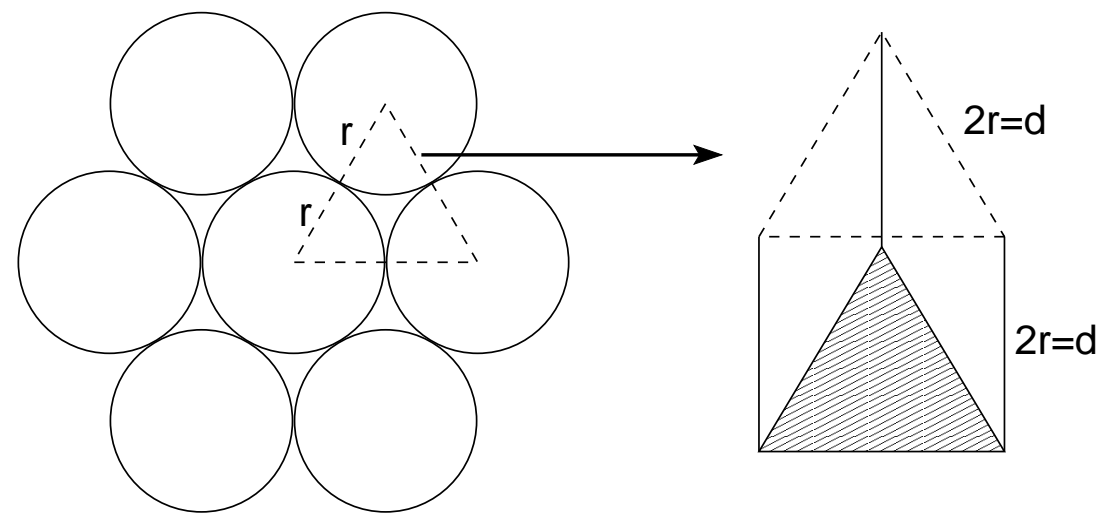

6.8. ábra. A pórusos közeget létrehozó gyöngyök egyrétegú, hexagonális, szoros illeszkedésú elhelyezkedésének sematikus rajza.

Ha meggondoljuk, hogy a 6.8. ábrán látható háromszög szabályos, tehát minden belsô szöge $60^{\circ}$, akkor elmondhatjuk, hogy a hasáb belsejében levő szabad térfogatot megkapjuk, ha a hasáb térfogatából kivonjuk a három darab egyforma, $\frac{1}{6}$-od gömbcikk térfogatát. A leírtak alapján a szabad térfogati hányad az

$$
\varepsilon=\frac{V_{\text {hasáb }}-3 \cdot\left(\frac{V_{\text {gyöngy }}}{6}\right)}{V_{\text {hasáb }}} .
$$

egyenlettel számítható. A képletbe behelyettesítve, és a múveleteket elvégezve az

$$
\varepsilon=1-\frac{1}{3 \sqrt{3}} \pi=0,396
$$

kifejezéshez jutunk, melyben a gyöngyök méretétől függő paraméter már nem szerepel. A kapott eredményt értelmezve azt mondhatjuk, hogy ezen porozitás értéknél kisebb az adott összeállítás mellett nem lehetséges, hiszen a gyöngyök alaktartóak, valamint fontos megállapítani azt is, hogy különböző gyöngyméretek alkalmazásakor a porozitásnak a rendszerre gyakorolt hatása a kísérleti hibán belül állandó. A 6.8. ábrán látható háromszöghöz hasonló háromszögekkel az egyrétegú elrendezés jól lefedhető, kivéve a közvetlenül az edény fala mellett levő gyöngyöket, melyek miatt egymáshoz tökéletesen illeszkedő gyöngyök esetén 
sem érhetô el az elméletileg meghatározott porozitás.

A gyöngyök több rétegben való elhelyezésekor a szabad térfogati hányad kiszámítására szintén a legszorosabb illeszkedést biztosító hexagonális rácsot vettem alapul, melyet a 6.9. ábra segítségével szemléltetek. A hatszög alapú hasáb térfogata az alapterület és a hasáb magasságának a szorzataként adódik, ahol az alaplap hat darab szabályos, egybevágó háromszögre bontható fel, melyeknek oldalhossza $2 r$, magassága a Pitagorasz-tétel alapján $m=\sqrt{3} r$, s így területe $T_{\text {háromszög }}=\sqrt{3} r^{2}$. A hasáb magassága felírható két olyan egy-

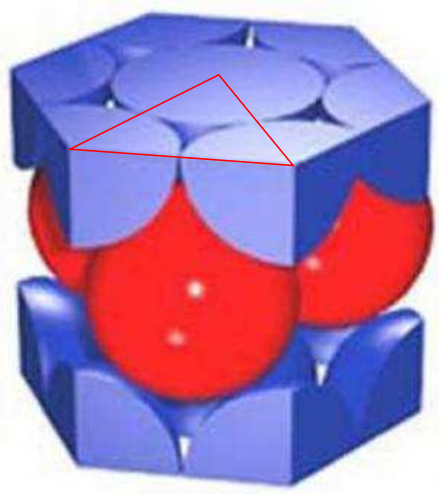

6.9. ábra. A pórusos közeget létrehozó gyöngyök többrétegú, hexagonális, szoros illeszkedésû elhelyezkedése [87].

bevágó tetraéder magasságának összegeként, melynek alaplapja a 6.9. ábrán pirossal rajzolt háromszög, negyedik csúcsa pedig a hasáb belsejében, a piros háromszög alatt levő gömb középpontja. A hasáb $M$ magassága ezt a gömbközéppontot köti össze a piros háromszögbe írható kör középpontjával, ami a háromszög magasságának a csúcstól távolabbi harmadolópontja. Az előbbiek alapján tehát

$$
M=2 \sqrt{4 r^{2}-3 \cdot \frac{4}{9} r^{2}}=2 \sqrt{\frac{8}{3} r}
$$

egyenlet írható fel a hasáb magasságára a Pitagorasz-tétel segítségével. Ezek után a hasáb magasságának és alapterületének ismeretében $V_{\text {hasáb }}=24 \sqrt{2} r^{3}$ kifejezéshez jutunk, amely a (6.11) egyenletben szereplő „összes térfogatnak” felel meg. A hasábban levő gyöngyök össztérfogatát a 6.9. ábra alapján könnyedén kiszámíthatjuk, ha összeadjuk három teljes gömb, két félgömb és tizenkét $\frac{1}{6}$-od gömb térfogatát. Ekkor a $V_{\text {gyöngy,össz }}=8 r^{3} \pi$ egyenlőséggel adható meg a hasábban a gyöngyök által elfoglalt össztérfogat. A porozitás tehát $\varepsilon=\frac{V_{\text {hasáb }}-V_{\text {gyöngy,össz }}}{V_{\text {hasáb }}}$ alakban számolható, melybe behelyettesítve

$$
\varepsilon=1-\frac{\pi}{3 \sqrt{2}}=0,260
$$


kifejezés adódik. Ezen érték természetszerúen kisebb, mint az egyrétegú elrendezés esetén meghatározott, hiszen itt a gyöngyök alatt és felett a sík határfelület helyett más gyöngyök helyezkednek el, melyeknek a felülete benyúlik a két gyöngy közötti szabad térrészbe, ezzel csökkentve annak nagyságát.

A szabad térfogati hányad értékét kísérletileg is meghatároztam mind tömbfázis, mind egyrétegú elrendezés esetén, melyek közül először a tömbfázisban végzett kísérleteket részletezem. Egy $50 \mathrm{~cm}^{3}$ térfogatú mérôlombikot jelre töltöttem $2 \mathrm{~mm}$ átmérőjû́ gyöngyökkel többszöri rázogatás, kocogtatás mellett, hogy a lehetô legszorosabb elrendezéshez jussak. Ekkor bürettából ioncserélt vizet csepegtettem a lombikba, és igyekeztem tovább tömöríteni a benne levő töltetet, amit ha szükséges volt, újabb gyöngyök hozzáadásával pótoltam ki, hogy a lombik a lehető legpontosabban legyen jelretöltve. A vízzel való feltöltés után a bürettáról leolvastam a fogyás értékét, és a (6.11) egyenletet használva kiszámoltam a rendszer porozitását, összes térfogatként a lombik térfogatával számolva, szabad térfogatnak pedig az adagolt víz térfogatát véve. A mérést $3 \mathrm{~mm}$ átmérôjű gyöngyökkel is a leírt módon végeztem el, míg 4 és $5 \mathrm{~mm}$ gyöngyátmérő esetén annyit módosítottam a módszeren, hogy $250 \mathrm{~cm}^{3}$ térfogatú lombikot használtam, hogy az edény falának görbülete a nagyobb méretú gyöngyök elhelyezkedését ne változtassa jobban, mint az eredeti összeállítás esetén. Az eredményeket a 6.1. táblázatban foglaltam össze, amelyból egyértelmúen látszik, hogy tömbfázisú elrendezést alkalmazva a porozitás értékek kísérleti hibán belül megegyeznek, tehát függetlenek a gyöngyök méretétôl, ugyanakkor a mérési eredmények eltérnek a (6.15) egyenlettel meghatározott értéktôl, aminek az oka a gyöngyök tökéletlen elrendeződésében keresendő. Mivel nem tudjuk megvalósítani a legszorosabb illeszkedést, és a rendszerünk véges nagyságú, az edény fala közelében fellépő porozitás-változás jelentős, a tényleges szabad térfogat nagyobb, mint az elméletileg számolt, ami a porozitás értékének növekedéséhez vezet. A szabad térfogati hányad értékét egyrétegû elrendezés mellett is meghatároztam Hele-Shaw

6.1. táblázat. A porozitás függése a gyöngymérettől tömbfázisú elhelyezkedés esetén.

\begin{tabular}{|c|c|}
\hline Gyöngyátmérő $(\mathrm{mm})$ & Porozitás \\
\hline \hline 2 & $0,391 \pm 0,002$ \\
\hline 3 & $0,399 \pm 0,010$ \\
\hline 4 & $0,409 \pm 0,011$ \\
\hline 5 & $0,395 \pm 0,018$ \\
\hline
\end{tabular}

edény segítségével. Először 2 mm vastag távtartóval összeszereltem az edényt, majd bürettából ioncserélt vizet adagolva meghatároztam a reakciótér pontos térfogatát. Ezt követôen szétszedtem, szárazra töröltem, és 2 mm átmérőjú gyöngyökkel feltöltve újra összeszereltem a berendezést. Az edényt büretta segítségével töltöttem tele vízzel, ezzel megmérve a sza- 
bad térfogatot a belsô térrészben, amelyet a (6.11) egyenletbe behelyettesítve kiszámoltam a rendszer porozitását. A mérést mind a négy különböző átmérőjű gyöngy esetén elvégeztem, és az eredményeket a 6.2. táblázatban foglaltam össze. Az adatokat elemezve megállapíthatjuk, hogy 3; 4; és 5 mm átmérőjú gyöngyöket használva a pórusos rendszer kialakításához a porozitás értékek kísérleti hibán belül megegyeznek, a 2 mm-es távtartószélességhez tartozó érték viszont kis mértékben eltér. Ennek az eltérésnek az oka a kísérleti tapasztalatok alapján azzal magyarázható, hogy a névlegesen $2 \mathrm{~mm}$ átmérőjú gyöngyök mérete nem pontosan 2 mm, mert a reakcióedényt megrázva egy kis mértékú oldalirányú mozgás volt megfigyelhetô. A gyöngyöknek ezen pici szélességbeli különbsége a távtartóhoz képest elegendő lehet a porozitás ilyen mértékú növeléséhez.

6.2. táblázat. A porozitás függése a gyöngymérettől egyrétegú elhelyezkedés esetén.

\begin{tabular}{|c|c|}
\hline Gyöngyátmérő $(\mathrm{mm})$ & Porozitás \\
\hline \hline 2 & $0,514 \pm 0,001$ \\
\hline 3 & $0,430 \pm 0,009$ \\
\hline 4 & $0,448 \pm 0,001$ \\
\hline 5 & $0,447 \pm 0,004$ \\
\hline
\end{tabular}

A tapasztalatok összességében azt mutatják, hogy a közeg porozitása egyrétegú elrendezés esetén sem függ a gyöngyök méretétől, ahogyan ez az elméleti átgondolás alapján is nyilvánvaló lett. Ezen vizsgálat elvégzése fontos volt számomra, hiszen kísérleteim egy részét olyan Hele-Shaw edényben végeztem el, melyekben a gyöngyök egyrétegú konfigurációja biztosította a pórusos közeget.

\subsubsection{A permeabilitás meghatározása}

A közeg porozitása még kísérleti körülmények között is jó közelítéssel független az azt felépítő gyöngyök méretétől. Felmerül a kérdés, hogy a rendszerre jellemző másik sajátság, a permeabilitás, hogyan változik a közeg szerkezetétôl függóen.

A permeabilitás mérésének a módját a 6.10. ábrán feltüntetett berendezésen mutatom be. A kísérlet lényege, hogy egy függőlegesen orientált Hele-Shaw edény távtartójába egy tartórácsot illesztettem, melynek keresztmetszete kisebb volt a távtartó keresztmetszeténél, így megakadályozta a töltetként szolgáló gyöngyök lefelé történő mozgását. A közlekedő edények elvét felhasználva a töltőtartályból ionizált vizet áramoltattam a tölteten keresztül felfelé, amíg az adagolótartály meg nem telt. Ez a fajta feltöltés megakadályozta a légbuborékok beszorulását a szemcsék közé, illetve a párhuzamos mérések között a folyadékot nem kellett kiönteni. Az ismert térfogatú adagoló tartályból a vizet keresztülengedtem a 


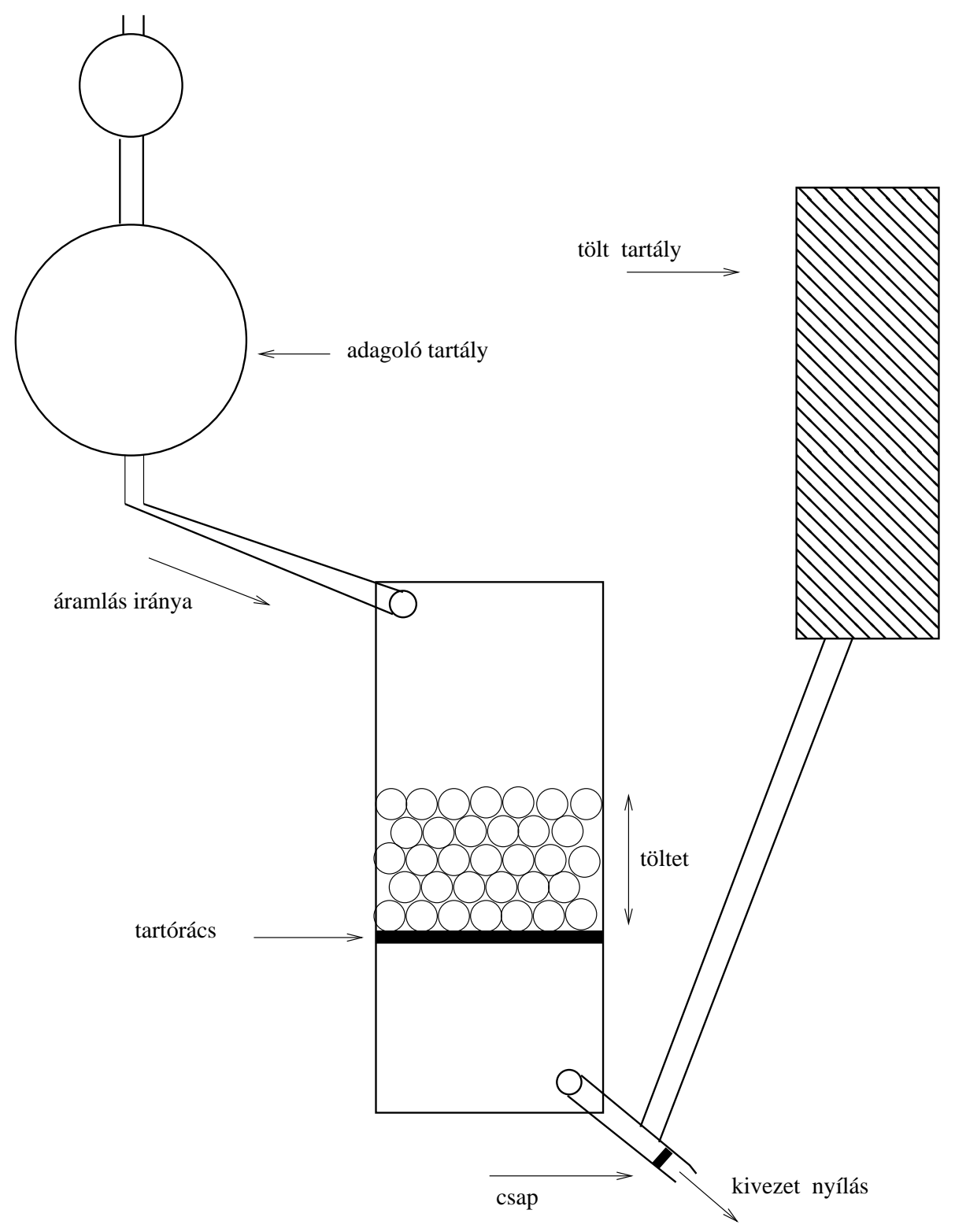

6.10. ábra. A permeabilitás mérésére használt berendezés sematikus rajza.

tölteten, és mértem az átfolyáshoz szükséges idôt minden egyes gyöngyméret esetén. A mérések eredményét a 6.3. táblázatban foglaltam össze, melyből egyértelmúen kitúnik, hogy a gyöngyök méretének a növekedésével az átfolyási idő számottevően csökken. Ebből azonnal levonható az a következtetés, hogy a közeg permeabilitása jelentôsen befolyásolja a folyadék áramlását a közegen keresztül. Annak érdekében, hogy ezt a hatást mennyiségileg is le tudjam írni, a permeabilitás számszerú kifejezésére volt szükség, melyhez a

$$
K=\frac{V}{t} \eta \frac{l}{A \Delta p}
$$


6.3. táblázat. Az átfolyási idő változása a gyöngyátmérô növekedésével.

\begin{tabular}{|c|c|}
\hline Gyöngyátmérő (mm) & Átfolyási idő (s) \\
\hline \hline 2 & $66,29 \pm 2,27$ \\
\hline 3 & $29,65 \pm 0,11$ \\
\hline 4 & $18,09 \pm 0,16$ \\
\hline 5 & $14,06 \pm 0,03$ \\
\hline töltet nélkül & $10,27 \pm 0,36$ \\
\hline
\end{tabular}

egyenletet használtam, ahol $A$ a töltetet tartó rács résfelületét, $V$ az átáramoltatott térfogatot, $t$ az átáramlás idejét, $l$ a töltet hosszát és $\eta$ a fluidum dinamikus viszkozitását jelöli. A számítás alkalmával tudjuk, hogy $A=0,8 \mathrm{~cm}^{2}, V=257,5 \mathrm{~cm}^{3}, l=84 \mathrm{~cm}$, és $\eta=10^{-3} \mathrm{kgm}^{-1} \mathrm{~s}^{-1}$ értékek a különböző mérések alatt állandóak voltak, míg az átfolyáshoz szükséges idő függött a gyöngymérettól, de értéke ismert volt a kísérletek után. Már csak a nyomás értékének változását kellett meghatározni, hogy a pórusos közeg permeabilitásának számolása lehetôvé váljon. Ehhez azt kell figyelembe vennünk, hogy a nyomás különböző mértékben változik a töltött és a töltetlen oszlopon, tehát a mérés folyamán a nyomásesés két tag összegeként adható meg, amint ezt a 6.11. ábra be is mutatja. Ha csak egyféle permeabilitású közegünk

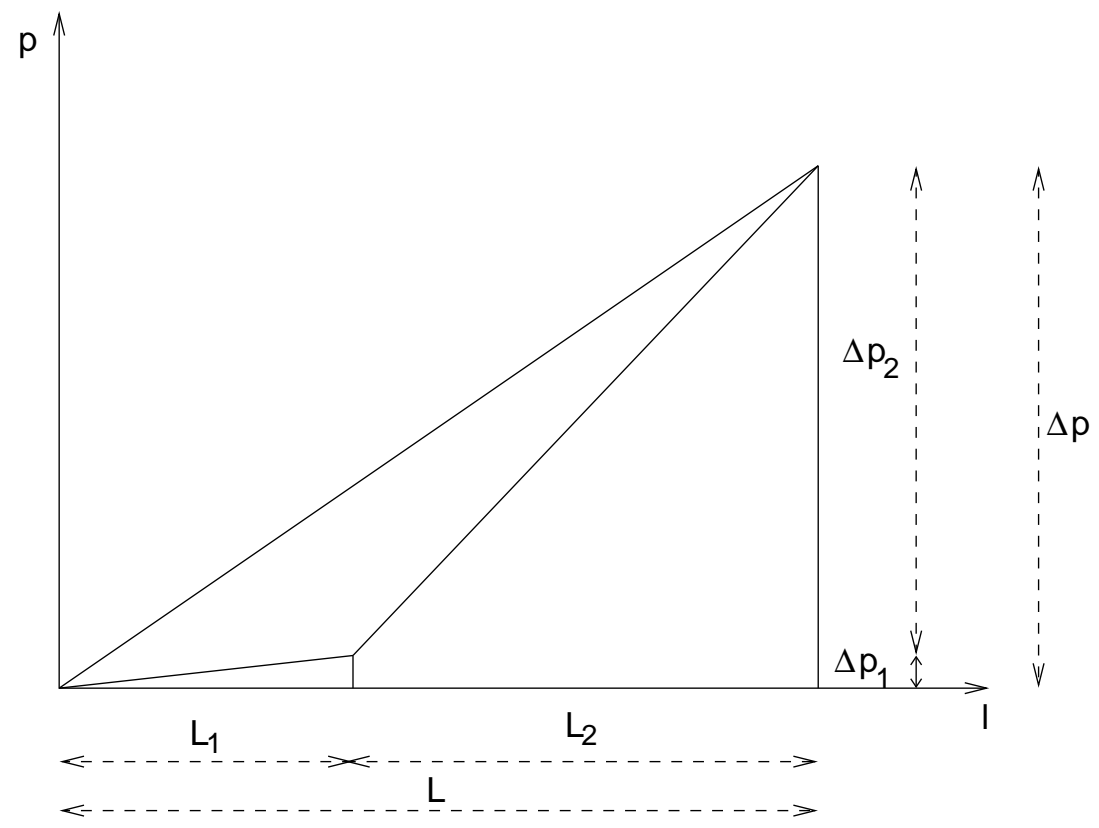

6.11. ábra. A nyomásesés változása az eltérő permeabilitású rétegek hosszának függvényében. 
van, akkor a következő egyenlet írható fel

$$
\frac{V}{t_{1}}=\frac{K_{1} A \Delta p_{1}}{\eta L}
$$

ahol az 1-es index mutatja, hogy a paraméterek a töltetlen oszlopra vonatkoznak. Az egyenletből $K_{1}$ értéke kiszámolható, hiszen $\Delta p_{1}=\rho g h$ egyenletből minden adatot ismerünk (a $h$ érték jelen esetben $l$-el egyenlő, tehát $84 \mathrm{~cm}$ ). Azt is tudjuk, hogy amennyi víz az egyik részbôl kifolyik, a másikba ugyanannyinak kell befolynia, vagyis két különböző permeabilitású, egymáshoz illeszkedő egység esetén felírható, hogy

$$
\frac{V}{t}=\frac{K_{1} A \Delta p_{1}}{\eta L_{1}}=\frac{K_{2} A \Delta p_{2}}{\eta L_{2}}
$$

ahol a 2-es index a pórusos közeghez tartozó adatokat jelenti. A (6.17) és a (6.18) kifejezésekből következik, hogy

$$
\frac{t}{t_{1}}=\frac{K_{1} \Delta p L_{2}}{K_{2} \Delta p_{2} L}
$$

melyből a töltött oszlopra vonatkozó nyomásesést kifejezve kapjuk a

$$
\Delta p_{2}=\frac{K_{1} \Delta p L_{2}}{K_{2} L} \frac{t_{1}}{t}
$$

egyenletet. A (6.20) egyenlőségből a nyomásesés értékét visszahelyettesítve a (6.19) kifejezésbe, valamint a megfelelő átalakításokat elvégezve a pórusos rendszer permeabilitására az alábbi összefüggés írható fel

$$
K_{2}=K_{1} \frac{L_{2}}{L\left(t / t_{1}\right)-L_{1}},
$$

melybe behelyettesítve a rendelkezésünkre álló adatokat, a múvelet elvégezhetô. A számolás eredményeként kapott értékeket a 6.4. táblázatban tüntettem fel, melyekből jól látszik, hogy a gyöngyök méretének növekedésével a permeabilitás, azaz a közeg áteresztő képességének mértéke folyamatosan nô. A pórusos közeg permeabilitása lamináris áramlás esetén jósolható a Carman-Kozeny egyenlet alapján:

$$
K_{C K}=\frac{\varepsilon^{3} d^{2}}{180(1-\varepsilon)^{2}},
$$

ahol $\varepsilon$ a porozitás és $d$ a közeget alkotó szemcsék átmérôje. Az egyenlet alapján számolt értékek jó egyezésben voltak a mérési eredményekből kapottakkal 3; 4; és 5 mm átmérôjű gyöngyök esetén, ha a konstans értékét 490 \pm 10 -nek választottuk. Ezen kis módosítás szükségessége abból adódik, hogy egyrétegú pórusos közeg esetén a fal és a gyöngyök közötti nagyobb csatornák számottevő hatást fejtenek ki a rendszer áteresztôképességére. A 2 mm-es 
gyöngyökből alkotott töltet permeabilitása ugyanakkor jelentősen eltért a számítható értéktôl, aminek a szemcsék és a távtartó méretében levő kicsi, de jelen esetben fontos különbség volt az oka.

6.4. táblázat. A mért permeabilitás értékek különböző átmérőjû gyöngyökből létrehozott pórusos közegben.

\begin{tabular}{|c|c|}
\hline Gyöngyátmérő $(\mathrm{mm})$ & Permeabilitás $\left(10^{-9} \mathrm{~m}^{2}\right)$ \\
\hline \hline 2 & $1,72 \pm 0,01$ \\
\hline 3 & $4,53 \pm 0,04$ \\
\hline 4 & $9,34 \pm 0,03$ \\
\hline 5 & $14,82 \pm 0,51$ \\
\hline
\end{tabular}

\subsection{A pórusos közeg hatása}

A pórusos közegú kísérletek paramétereit úgy választottam ki, hogy biztosítsam a homogén közegú vizsgálatokkal való összehasonlíthatóság feltételeit. A reaktánsokat a 4.1. táblázat második sorának megfelelő koncentrációban alkalmaztam, mert ekkor a stabil alakzat mennyiségi leírására szolgáló keveredési hossz elegendôen nagy, így a kívánt pontossággal meghatározható, de a reakcióban fejlődő hő hatására bekövetkező sûrúségcsökkenés még a lehetô legjobban kiküszöbölhetô a $3^{\circ} \mathrm{C}$-ra történố termosztálással.

Már az elsô kísérletek elvégzésekor szemmel látható különbség mutatkozott a homogén közegú kísérletekhez képest, amint azt a 6.12. ábra szemlélteti. A képeken az indikátorcsere miatt az alkalmazott színszúrő mellett világosabb színnel a nagyobb sưrüségú termékoldat, sötétebb színnel a kisebb súrúségú reaktánsoldat rendelkezik. A kísérletekben a szoros illeszkedéssel elhelyezett gyöngyök (6.12. (b) ábra) alkalmazásakor létrejött alakzat hasonlít a homogén közegben tapasztalthoz, de a keveredési hossz jelentős mértékben lecsökkent. A reakciókat $2 ; 3 ; 4$; és $5 \mathrm{~mm}$ vastagságú távtartóval végeztem és minden távtartóhoz a vele egyező méretû gyöngyöt használtam. A homogén rendszerben végzett kutatásokkal való összehasonlíthatóság miatt $1 \mathrm{~mm}$ átmérőjű gyöngyöket is vásároltunk, de ezek a hûtés, mozgatás közben oly mértékben feltöltôdtek elektrosztatikusan, hogy a viselkedésük teljesen eltért a nagyobb gyöngyökétől, így ezekkel nem hajtottam végre reakciót. A gyöngyök méretének a változtatása egyértelmúen kihatott a mintázat elnyúltságára, ezt illusztrálja a 6.13. ábra $4 \mathrm{~cm}$ magas távtartó esetén. A képen látható rácshibák nem okoztak észrevehető torzulást a mintázatban. Szembetûnő, hogy az alakzat egyre elnyúltabbá válik a gyöngyök méretének növekedésével. Az előzőekben leírtak alapján elmondhatjuk, hogy a közegnek a 

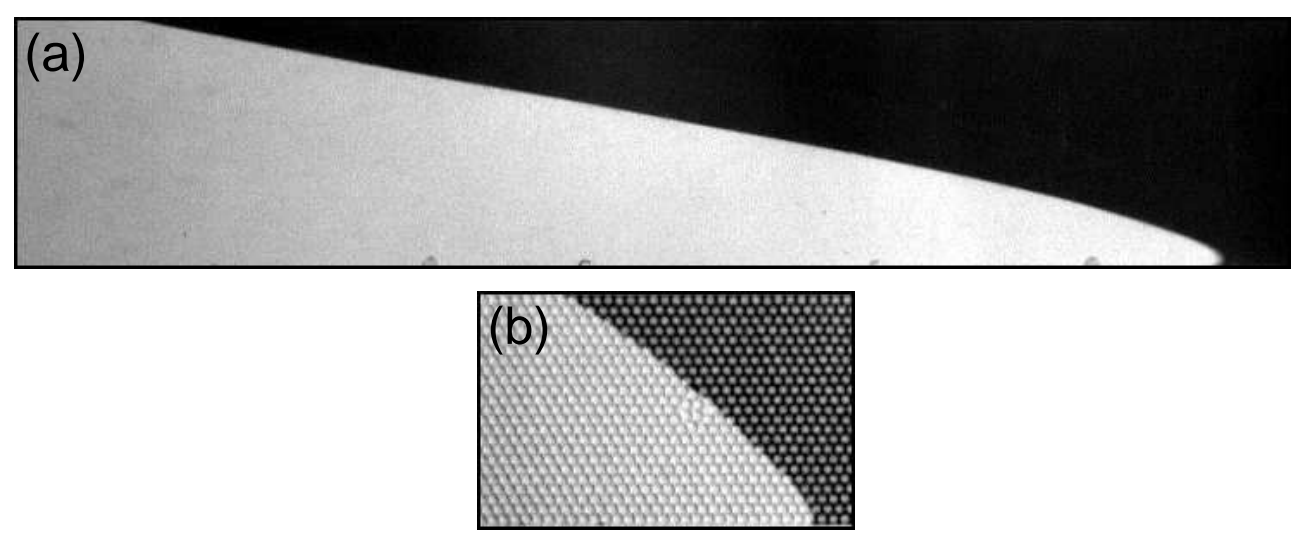

6.12. ábra. A homogén (a), és a pórusos (b) közegben kialakuló stabil alakzat összehasonlítása $4 \mathrm{~cm}$ magas és $2 \mathrm{~mm}$ széles távtartó esetén, $3^{\circ} \mathrm{C}$-ra termosztált reakciókban. Világosabb színnel a termékoldat, sötétebb színnel a reaktánsoldat látható. Az alkalmazott koncentrációk a reaktánselegyben: $\left[\mathrm{K}_{2} \mathrm{~S}_{4} \mathrm{O}_{6}\right]_{0}=5,00 \mathrm{mM},\left[\mathrm{NaClO}_{2}\right]_{0}=20 \mathrm{mM}$, és $[\mathrm{NaOH}]_{0}=2,5 \mathrm{mM}$, $[\text { brómfenolkék }]_{0}=0,08 \mathrm{mM}$.
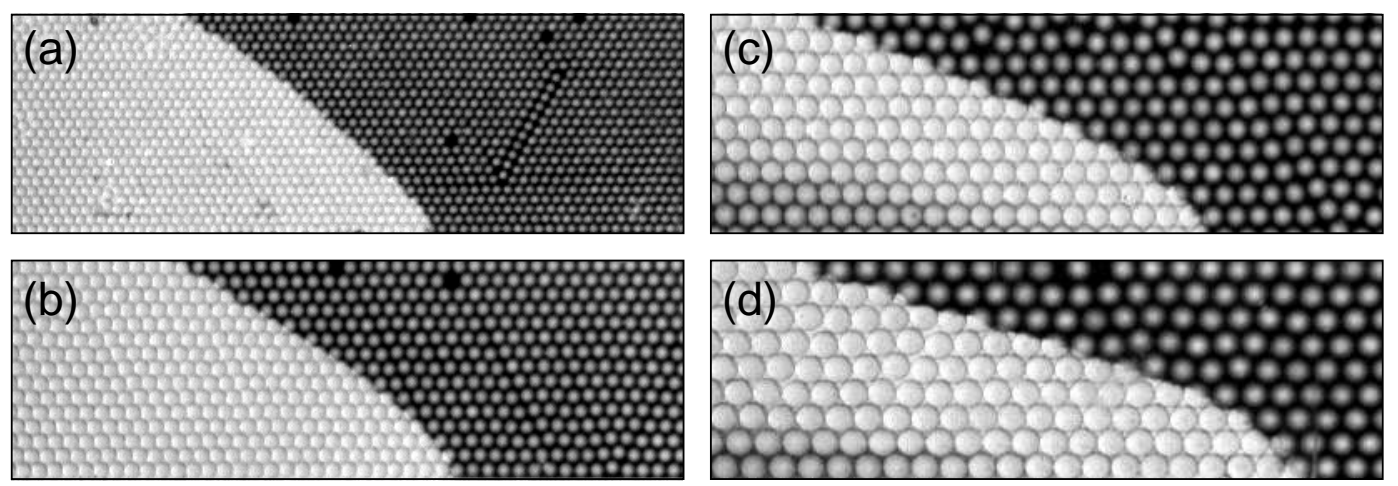

6.13. ábra. A kialakuló mintázat képei (a) $2 \mathrm{~mm}$, (b) $3 \mathrm{~mm}$, (c) $4 \mathrm{~mm}$ és (d) $5 \mathrm{~mm}$-es edényvastagság és $4 \mathrm{~cm}$-es edénymagasság esetén, $3{ }^{\circ} \mathrm{C}$-on végrehajtott reakciókban. $\mathrm{Az}$ alkalmazott koncentrációk a reaktánselegyben: $\left[\mathrm{K}_{2} \mathrm{~S}_{4} \mathrm{O}_{6}\right]_{0}=5,00 \mathrm{mM},\left[\mathrm{NaClO}_{2}\right]_{0}=20 \mathrm{mM}$, és $[\mathrm{NaOH}]_{0}=2,5 \mathrm{mM}$, [brómfenolkék $]_{0}=0,08 \mathrm{mM}$.

gyöngymérettôl függố permeabilitása felelős ezen hatásért. A gyöngyök felszíne befolyással volt a mintázat alakjára is, melyben egy periódikus hullámzás figyelhető meg, de ettől függetlenül pórusos közeg esetén is létrejött az állandósult alakzat (lásd a 6.14. ábra).

A kísérletek elvégzése során kapott keveredési hossz értékeket az edénymagasság függvényében ábrázoltam, és a mérési pontokra hatványfüggvényt illesztettem, melyet a 6.15. ábra mutat be. A 2 mm átmérőjű gyöngyök alkalmazásakor a függvénykapcsolat

$$
L_{m} / \mathrm{cm}=(0,265 \pm 0,018)\left(L_{z} / \mathrm{cm}\right)^{1,12 \pm 0,06}
$$




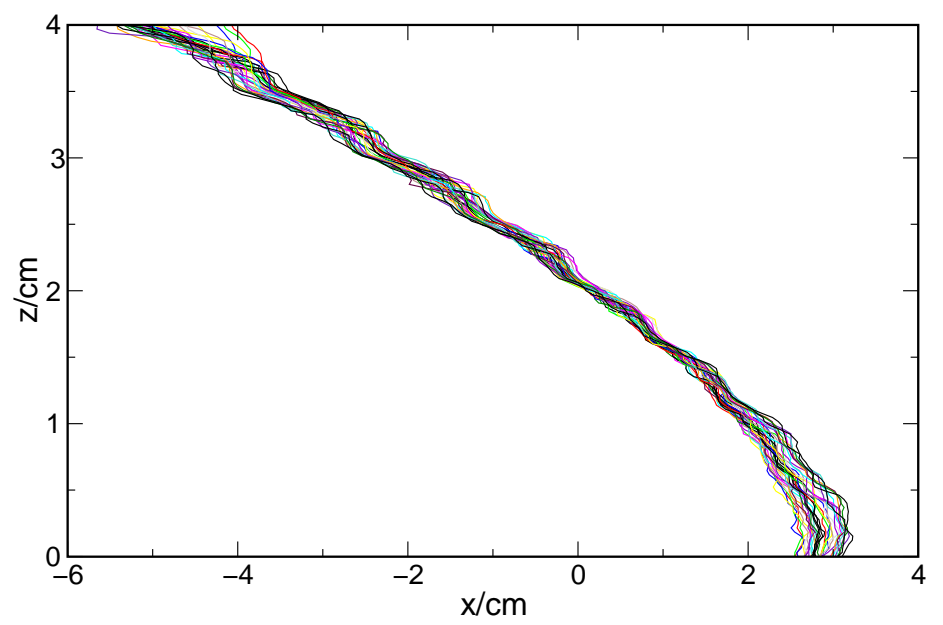

6.14. ábra. A 38 db, időkülönbséggel korrigált, idôben állandó mintázat egymásra vetített alakja. A profil egyenetlenségét az alkalmazott gyöngyök felszíne okozza.

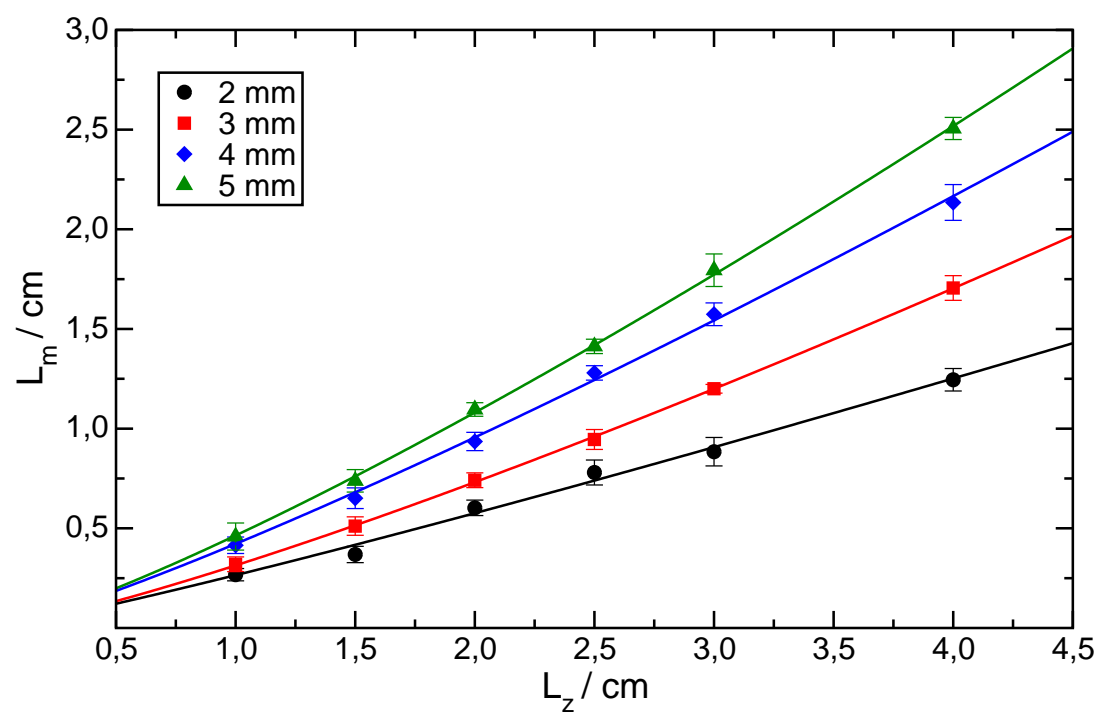

6.15. ábra. A keveredési hossz az edénymagasság függvényében pórusos közegben, $3{ }^{\circ} \mathrm{C}$-on végzett kísérletek esetén, különbözú vastagságú távtartók használatakor. A folytonos vonal a hatványfüggvény-illesztés eredményét mutatja.

egyenlettel írható le (fekete vonal), míg a 3 mm vastag távtartó esetén

$$
L_{m} / \mathrm{cm}=(0,314 \pm 0,005)\left(L_{z} / \mathrm{cm}\right)^{1,22 \pm 0,01}
$$

kifejezés lesz igaz (piros vonal). A reakcióedény vastagságát 4 mm-re növelve a

$$
L_{m} / \mathrm{cm}=(0,422 \pm 0,016)\left(L_{z} / \mathrm{cm}\right)^{1,18 \pm 0,03}
$$


egyenlőséghez jutunk (kék vonal), míg a legnagyobb, 5 mm átmérőjú gyöngyöket használva a keveredési hosszat

$$
L_{m} / \mathrm{cm}=(0,464 \pm 0,009)\left(L_{z} / \mathrm{cm}\right)^{1,22 \pm 0,02}
$$

alakú egyenlettel számolhatjuk (zöld vonal). Az ábra alapján azt is megállapíthatjuk, hogy az alakzat elnyúltsága nemcsak a gyöngyök méretétôl függ, hanem a távtartó magasságának növelésével együtt a keveredési hossz értéke is nő.

Ha összehasonlítjuk a homogén és az inhomogén rendszerben végzett kísérletek eredményeit, azt tapasztaljuk, hogy az illesztett hatványfüggvények kitevői azonos közeg esetén kísérleti hibán belül jó egyezésben vannak ( $2 \mathrm{~mm}$ átmérőjű gyöngyök esetén tér el kis mértékben, a gyöngyök méretéből adódó tökéletlen térkitöltés miatt), és különböző közeg esetén is csak körülbelül 0,08 a különbség. Ezzel szemben az arányossági tényező értéke jelentősen változik mind az azonos, mind a különböző közegek összehasonlítása esetén. Annak érdekében, hogy ezen arányossági tényezốt mennyiségileg jellemezni tudjuk, összehasonlítottuk az azonos edénymagasság mellett, különböző permeabilitású közegek esetén kapott keveredési hossz értékeket, melynek eredményeit a 6.5. táblázat mutatja be.

6.5. táblázat. Az arányossági tényező $(E)$ és a hatványkitevő $(F)$ a keveredési hossz $\left(L_{m}\right)$ permeabilitástól $(K)$ való függését leíró egyenletben $\left(L_{m}=E K^{F}\right)$ különböző edénymagasságok $\left(L_{z}\right)$ esetén.

\begin{tabular}{|c|c|c|}
\hline$L_{z}(\mathrm{~cm})$ & $E$ & $F$ \\
\hline \hline 1,0 & $0,22 \pm 0,01$ & $0,27 \pm 0,03$ \\
\hline 1,5 & $0,31 \pm 0,01$ & $0,32 \pm 0,01$ \\
\hline 2,0 & $0,50 \pm 0,03$ & $0,29 \pm 0,02$ \\
\hline 2,5 & $0,64 \pm 0,05$ & $0,30 \pm 0,03$ \\
\hline 3,0 & $0,74 \pm 0,02$ & $0,33 \pm 0,01$ \\
\hline 4,0 & $1,04 \pm 0,01$ & $0,32 \pm 0,01$ \\
\hline
\end{tabular}

A görbék egyenleteiben megfigyelhető tendencia lehetôvé teszi, hogy a pontokra a

$$
L_{m} / \mathrm{cm}=(0,20 \pm 0,01)\left(L_{z} / \mathrm{cm}\right)^{1,20 \pm 0,02}\left(K / 10^{-9} m^{2}\right)^{0,30 \pm 0,02}
$$

kifejezés alapján illesszünk függvényt (lásd a 6.16. ábra). Ezen illesztés alapján elmondhatjuk, hogy a (6.27) egyenlet jól leírja a keveredési hossznak az edény magasságától és a közeg permeabilitásától való függését.

Összességében megállapítható, hogy a pórusos rendszer a közeg permeabilitása révén jelentôs hatással van a kialakuló mintázatot leíró keveredési hosszra, melynek $4 \mathrm{~cm}$ magas távtartó esetén, $3{ }^{\circ} \mathrm{C}$-ra termosztált rendszerben meghatározott értékeit a 6.6. táblázatban 


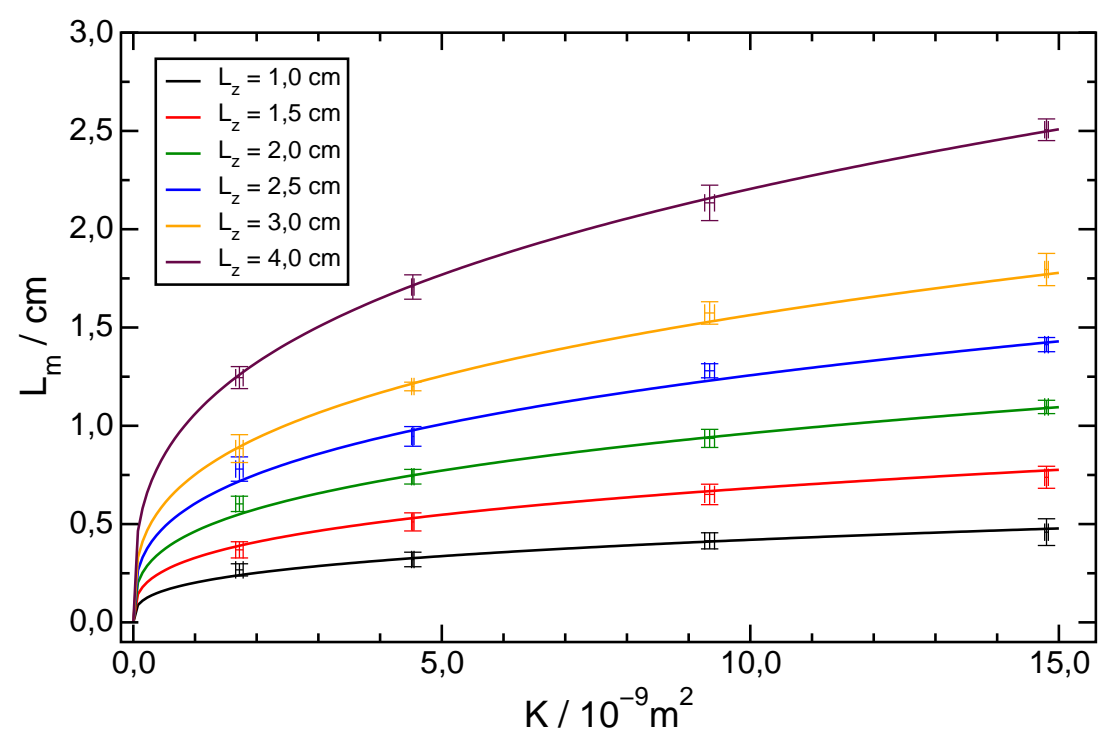

6.16. ábra. A keveredési hossz az alkalmazott közeg permeabilitásának a függvényében különböző edénymagasságok esetén. A folytonos vonal a közös egyenlet szerinti hatványfüggvény-illesztés eredményét mutatja.

6.6. táblázat. A keveredési hossz változása 1-5 mm vastag távtartó esetén homogén illetve inhomogén elrendezésnél.

\begin{tabular}{|c|c|c|}
\hline & \multicolumn{2}{|c|}{ Keveredési hossz $(\mathrm{cm})$} \\
\hline Résvastagság $(\mathrm{mm})$ & Homogén elrendezés & Inhomogén elrendezés \\
\hline \hline 1 & $3,02 \pm 0,03$ & - \\
\hline 2 & $6,09 \pm 0,04$ & $1,25 \pm 0,06$ \\
\hline 3 & $8,06 \pm 0,09$ & $1,71 \pm 0,06$ \\
\hline 4 & $8,57 \pm 0,04$ & $2,13 \pm 0,09$ \\
\hline 5 & - & $2,51 \pm 0,06$ \\
\hline
\end{tabular}

foglaltam össze, a könnyebb átláthatóság kedvéért. A felsorolásból látszik, hogy $5 \mathrm{~mm}$ széles távtartót használva homogén közegú reakciót nem végeztem. Ennek oka, hogy az alakzat oly mértékben elnyúlt, hogy a $42 \mathrm{~cm}$ hosszú reakciótér nem volt elég a front alakjának stabilizálódásához. Szintén nincs adat feltüntetve a táblázat pórusos közegre vonatkozó értékei között 1 mm vastag távtartó esetén, melynek oka az 1 mm átmérôjú gyöngyök korábbiakban említett elektrosztatikus töltődése.

A reakció közegének permeabilitása nemcsak a mintázat alakjára, hanem annak terjedési sebességére is hatást gyakorol, amint ezt a 6.17. ábrán be is mutatom. Az illesztett görbék egyenleteiben szereplő arányossági tényezőt és hatványkitevőt a 6.7. táblázatban foglaltam össze. A 6.17. ábra alapján jól látszik, hogy a front terjedési sebessége mind az edény magasságával, mind a gyöngyméret (azaz a permeabilitás) növekedésével nô, valamint a 6.7. táb- 


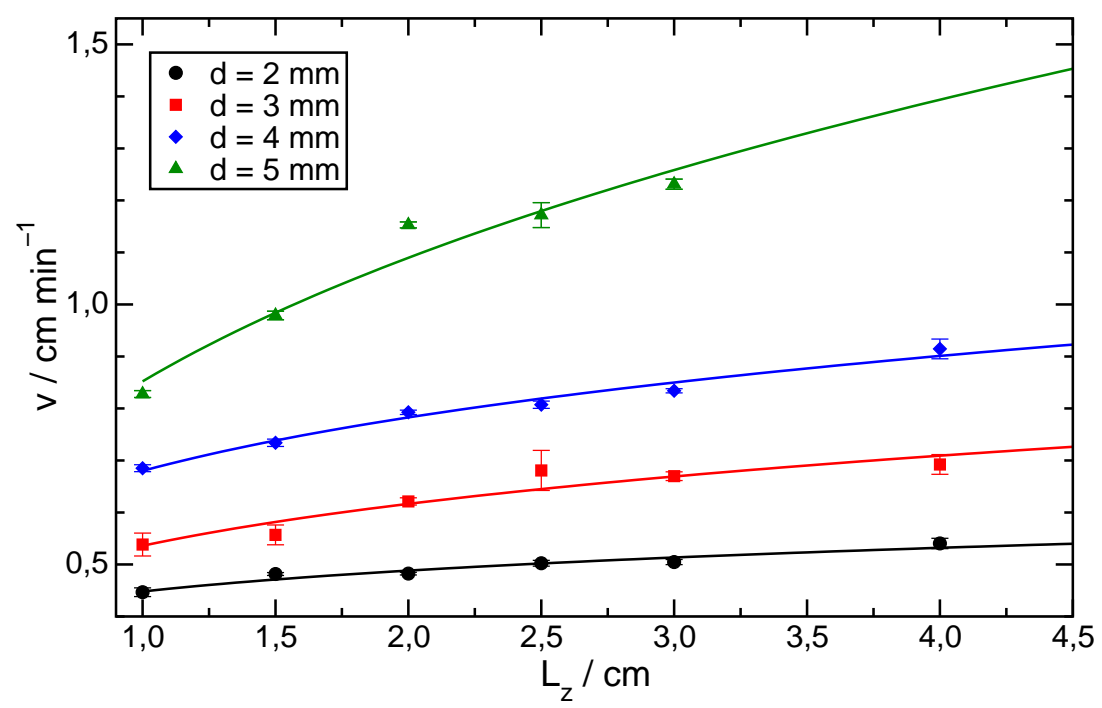

6.17. ábra. A reakciókban kialakult stabil alakzat sebessége az edény magasságának a függvényében különböző vastagságú távtartók esetén. A folytonos vonal a hatványfüggvényillesztés eredményét mutatja.

6.7. táblázat. Az arányossági tényező $(A)$ és a hatványkitevő $(B)$ a keveredési hosszat leíró egyenletben $\left(L_{m}=A L_{z}^{B}\right)$, valamint az arányossági tényező $(C)$ és a hatványkitevő $(D)$ a frontsebességet leíró egyenletben $\left(v=C L_{z}^{D}\right)$ különböző átmérôjű $(d)$ gyöngyökből alkotott inhomogén rendszer esetén.

\begin{tabular}{|c|c|c|c|c|}
\hline$d(\mathrm{~mm})$ & $A$ & $B$ & $C$ & $D$ \\
\hline 2 & $0,265 \pm 0,018$ & $1,12 \pm 0,06$ & $0,448 \pm 0,007$ & $0,124 \pm 0,016$ \\
\hline 3 & $0,314 \pm 0,005$ & $1,22 \pm 0,01$ & $0,536 \pm 0,018$ & $0,202 \pm 0,035$ \\
\hline 4 & $0,422 \pm 0,016$ & $1,18 \pm 0,03$ & $0,680 \pm 0,010$ & $0,203 \pm 0,016$ \\
\hline 5 & $0,464 \pm 0,009$ & $1,22 \pm 0,02$ & $0,852 \pm 0,034$ & $0,355 \pm 0,049$ \\
\hline
\end{tabular}

lázat adatait megvizsgálva elmondhatjuk, hogy az adott gyöngymérethez tartozó sebességi egyenletben a hatványkitevőt megkapjuk, ha a keveredési hosszat leíró egyenletben szereplő hatványkitevőből kivonunk egyet (ezen szabályosságtól kismértékben eltér az 5 mm átmérőjű gyöngyökkel végzett kísérletek eredménye).

\subsection{A skálázási törvény érvényessége}

Amint azt a „Célkitúzés” fejezetben már említettem, az eddigiekben ismertetett kísérleti munkám fő célja az volt, hogy a klorit-tetrationát autokatalitikus reakcióra elméletileg meghatározott skálázási törvény érvényességét megvizsgáljam valódi kísérleti rendszerekben. A reakciófront alakját leíró keveredési hosszt az edény magasságának a függvényében ábrázol- 
tam különböző kiindulási koncentráció, hőmérséklet, és folyadékvastagság esetén homogén, illetve pórusos rendszerben. A függvénykapcsolatot leíró kísérletileg meghatározott egyenleteket már korábban bemutattam, de most a könnyebb átláthatóság kedvéért ismét feltüntetem. A termosztálás szükségessége a $3 \mathrm{~mm}$ vastag folyadékrétegben kialakuló folytonosan keveredő alakzat miatt vált egyértelmúvé. Az 1 mm edényvastagságú, termosztált kísérletekben az illesztett hatványfüggvények a kezdeti koncentrációtól függetlenül kísérleti hibán belül megegyeztek, ezért az alakzat a

$$
L_{m} / \mathrm{cm}=(0,56 \pm 0,03)\left(L_{z} / \mathrm{cm}\right)^{1,19 \pm 0,04}
$$

egyenlettel volt jellemezhetố (ami a korábbi (6.7) egyenlet). A továbbiakban a méréseket $\left[\mathrm{K}_{2} \mathrm{~S}_{4} \mathrm{O}_{6}\right]_{0}=5,00 \mathrm{mM}$ összetételnek megfelelően végeztem, így a következőekben összehasonlításra kerülő rendszerek is csak az edény vastagságában és a közeg homogén, illetve pórusos voltában térnek el egymástól. A keveredési hossz edénymagasságtól való függését leíró egyenletek $L_{m} / \mathrm{cm}=A\left(L_{z} / \mathrm{cm}\right)^{B}$ alakúak, így az $A$ szorzótényező és a $B$ hatványkitevő értékeit a 6.8. táblázatban foglaltam össze, hogy megfelelően áttekinthető adathalmazhoz jussunk. A táblázat adataiból jól látszik, hogy a szorzótényezők adott elrendezésen belül a rés méretével együtt növekednek, ugyanakkor a hatványkitevő értékei megfelelő mértékben egyeznek a kísérleti összeállítástól függetlenül, ami lehetôvé teszi egy közös kitevő számítását, melynek értéke 1,23 $\pm 0,08$. Ez azt jelenti, hogy a keveredési hossz és az oldat magassága között valóban létezik egy skálázási törvény, ám ez jelentősen eltér az elméletileg jósolt négyzetes arányosságtól [49]. Ennek oka az elméleti és a kísérleti paraméterek különbözőségében keresendő. A dimenziómentesen végzett számítások eredményeit dimenzióval rendelkező formába átalakítva szembetűnő, hogy az ottani eredmények mm-es nagyságrendre vonatkoznak, míg a kísérletekben cm-es méretekben dolgoztam. Ezen esetekben a fal által a folyadék áramlására kifejtett hatás már oly mértékben eltérō, ami okozhat ekkora változást a függvény kitevőjében, hiszen az áramlási profilt nagyban befolyásolja,

6.8. táblázat. A keveredési hosszat leíró egyenletben $\left(L_{m}=A L_{z}^{B}\right)$ az arányossági tényező $(A)$ és a hatványkitevő $(B)$ értékeit összefoglaló táblázat homogén és pórusos közeg esetén.

\begin{tabular}{|c|c|c|c|c|}
\hline Résvastagság (mm) & $A$ & $B$ & $A$ & $B$ \\
\hline & \multicolumn{2}{|c|}{ Homogén elrendezés } & \multicolumn{2}{|c|}{ Pórusos elrendezés } \\
\hline 1 & $0,56 \pm 0,03$ & $1,19 \pm 0,04$ & - & - \\
\hline 2 & $0,99 \pm 0,10$ & $1,34 \pm 0,09$ & $0,27 \pm 0,02$ & $1,12 \pm 0,06$ \\
\hline 3 & $1,32 \pm 0,13$ & $1,31 \pm 0,08$ & $0,31 \pm 0,01$ & $1,22 \pm 0,01$ \\
\hline 4 & - & - & $0,42 \pm 0,02$ & $1,18 \pm 0,03$ \\
\hline 5 & - & - & $0,46 \pm 0,01$ & $1,22 \pm 0,02$ \\
\hline
\end{tabular}


hogy a falmenti álló folyadékréteg a teljes közegnek mekkora hányadát teszi ki. Azon számítások során, ahol figyelembe vették a rés vastagságának hatását, az általunk meghatározott skálázási törvényt találták érvényesnek [38], illetve kísérletileg megmutatták, hogy keskeny folyadékréteg esetén valóban négyzetes arányosság áll fenn a keveredési hossz és az oldatmagasság között [56].

Az említetteken túlmenően egy másik törvényszerúség létezését is megfigyeltem, amely egyszerre írja le a keveredési hossznak az edény magasságától és a közeg permeabilitásától való függését pórusos rendszerekben és a

$$
L_{m} / \mathrm{cm}=(0,20 \pm 0,01)\left(L_{z} / \mathrm{cm}\right)^{1,20 \pm 0,02}\left(K / 10^{-9} \mathrm{~m}^{2}\right)^{0,30 \pm 0,02}
$$

alakban adható meg (ami a korábbi (6.27) egyenlet).

\subsection{Az áramlási mezó meghatározása}

A háromdimenziós áramlást az edény falától 9 különböző távolságban, 2 milliméterenként vizsgáltuk. Az adott térrészben az áramlási profilokat a Mathematica programcsomag segítségével rajzoltuk ki, amelyek közül két párhuzamos kísérlet eredményeit a 6.18. ábra szemlélteti 4 mm távolságban az edény szélétől. Az ábrázolt síkok alapján elmondható, hogy a front elején levő lefelé áramlás és a front mögötti felfelé áramlás távolsága megegyezik párhuzamos kísérletek esetén, ami jól tükrözi a mérések reprodukálhatóságát.

A folyadéktér különböző metszeteinek összehasonlítását a 6.19. ábra mutatja be 2 (a); 6 (b); és 10 (c) mm távolságban a reakciótér szélétől. A falmenti rétegekben a folyadék
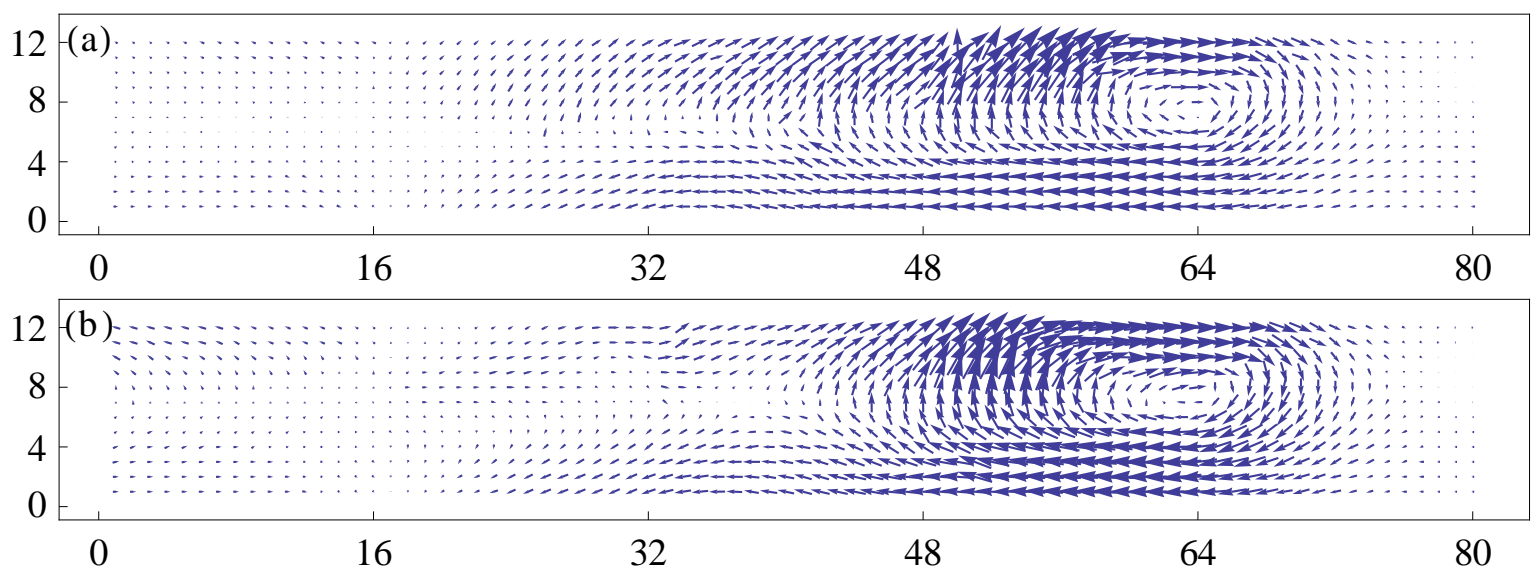

6.18. ábra. Párhuzamos mérések áramlási profilja $4 \mathrm{~mm}$ távolságban az edény szélétől. Az ábrázolt terület $41,0 \mathrm{~mm} \cdot 6,3 \mathrm{~mm}$ nagyságú. A tengelyeken a sík adott irányában levő részterületeinek száma látható. 

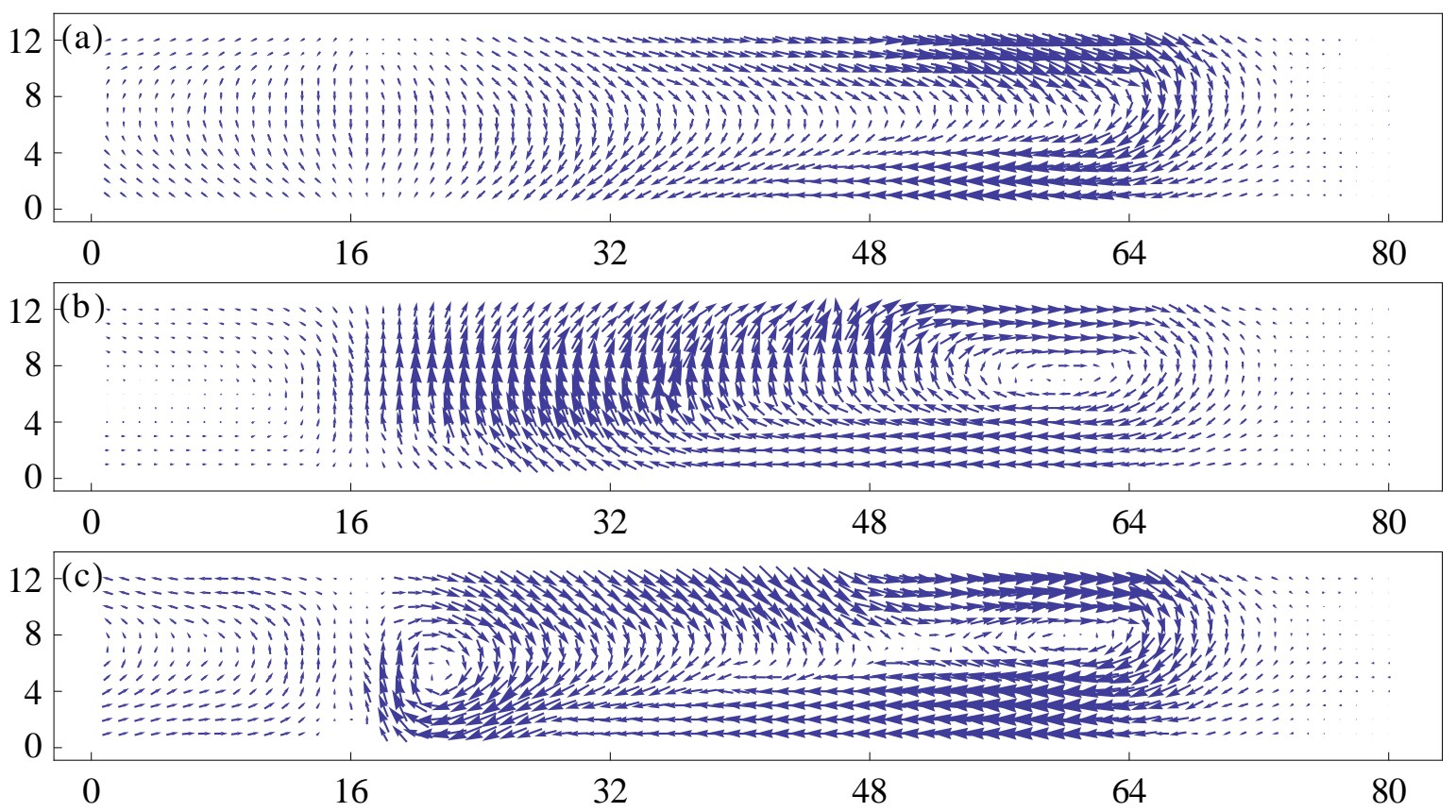

6.19. ábra. Áramlási profilok 2 (a); 6 (b); és 10 (c) mm távolságban a reakciótér falától. Az ábrázolt terület $41,0 \mathrm{~mm} \cdot 6,3 \mathrm{~mm}$ nagyságú. A tengelyeken a sík adott irányában levő részterületeinek száma látható.

áramlását egy elnyúlt konvekciós gyưrú jellemzi, mely a front elején erôteljes lefelé áramlást indukál, míg a közeg felfelé mozgása gyenge, és csak messze elnyúlva a front mögött észlelhető (a 6.19. ábra (a) képe). Távolodva az edény szélétôl a konvekciós gyưrú egyre rövidül, és a frontmenti lefelé áramlás mellett egy erős, hosszan elnyúló feláramlás is kialakul a közegben (a 6.19. ábra (b) képe), amit a reaktánsoldat színének a reakciófront mögötti megjelenése is bizonyít a kísérletek alkalmával [43]. A folyadék középső részérôl készített metszeten (a 6.19. ábra (c) képe) egy második konvekciós gyưrú kialakulását látjuk, amely az elsővel megegyező irányba forog. A két gyứrủ között az áramlás bonyolult, hiszen az óramutató járásával megegyezően (hátra- és felfelé) áramló közeg találkozik az előre- és lefelé mozgó közeggel. Ez az összetett áramlás a felelős a felülnézeti képen látható fordulópont kialakulásáért a front mentén. Az áramlási profil a faltól távolodva szimmetrikusan változik, ahogyan azt a megfigyelt alakzat alapján vártuk is.

A kísérlet felülnézeti, indikátorral megszínezett felvétele alapján a 9 különböző pozícióban meghatározott függóleges áramlási síkot egymás mellé illesztettük, és így az egész reakciótér háromdimenziós áramlási profiljához jutottunk, ami a 6.20. ábrán látható. Az eredményként kapott vektortér jó egyezésben van az indikátor jelenlétében megfigyelt alakzattal. Ezt támasztja alá a front elejének egységessége, a két feláramlási zóna szimmetrikus elhelyezkedése, valamint az áramlási tér közepén a második konvekciós gyưrú kialakulása is. Az ábra nem ad felvilágosítást a folyadékrétegek keresztirányú áramlásáról, mivel az 
alkalmazott kísérleti berendezés ennek detektálására nem volt alkalmas, de a közeljövőben tervezzük az áramlási profil ezirányú kiegészítését.

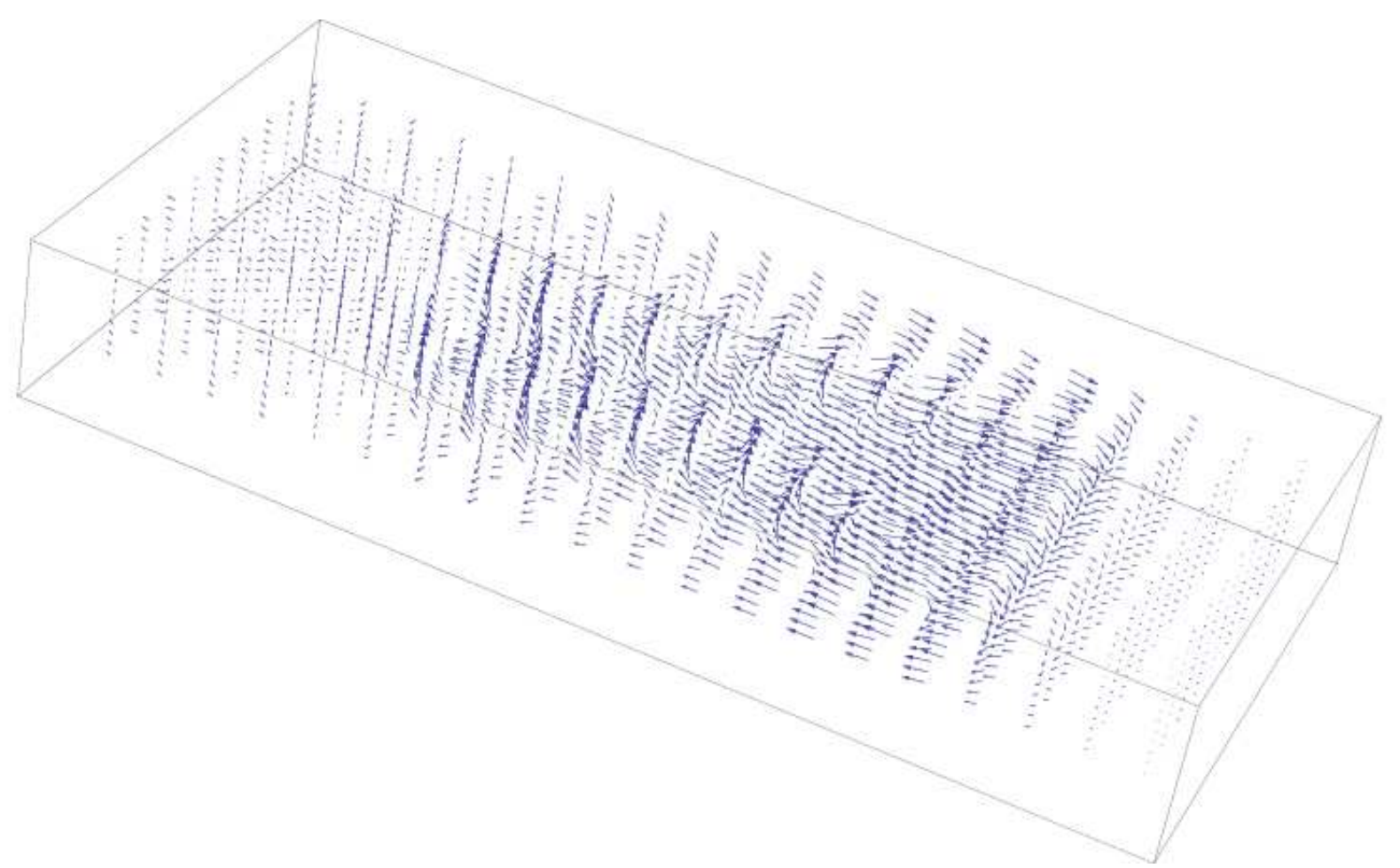

6.20. ábra. A reakciótér háromdimenziós áramlási profilja. 


\section{7. fejezet}

\section{Összefoglalás}

A világ, melyben élünk folyamatos mozgásban van az egészen parányi baktériumoktól kezdve a kontinens méretű ciklonokig. Vannak olyan mozgások, amik nem érintenek minket közvetlenül, bár jól láthatóak (például ha egy levél hullik lefelé a fáról) és vannak áramlások, amiket nem látunk, mégis alapvető jelentôségúek életünk szempontjából (például a talajba került szennyezôanyagok szétterjedése a földalatti vízkészletben). A kőzetlemezek egymásnak ütközése szintén nem közömbös az ott élők számára, mert bár ez a mozgás igen lassú, mégis óriási földrengések, szökőárak kiváltó oka lehet. Ezen néhány hétköznapi példa végiggondolása alapján egyértelmú lehet számunkra, hogy tudományos szempontból nem megengedhetố ezen események felszínes ismerete. Az imént felsorolt mozgások nagyon eltérôek időtartamot, közeget, erôsséget tekintve, de az közös bennük, hogy anyag áramlik egyik helyrôl a másikra.

Az anyag-transzportfolyamatokban elsődleges szerepet játszik a koncentrációgradiens által hajtott diffúzió, az elektromos erôtérben mozgó ionokra jellemzô migráció, és a Földünkön jelenlévő - még a hozzá nem értő hétköznapi ember számára is triviális - gravitációs tér által kiváltott közegmozgás. Ennek az egész közegre kiterjedő mozgásnak a hajtóereje egyaránt lehet a különböző anyagféleségek között meglévő viszkozitás, felületi feszültség, és sûrűségkülönbség is. A felületi feszültséggradiens által indukált konvekcióra példa a Marangoni instabilitás, amely a folyadék/gáz határfelületen figyelhető meg. A jelenség lényege, hogy a nagyobb felületi feszültségú folyadék magára húzza a kisebb felületi feszültségút a fázishatár mentén (a „,bor könnye” esetén a víz az alkoholt). A különböző folyadékok eltérő viszkozitás értékeit igyekeznek megfelelően befolyásolni a kőolaj másodlagos kitermelése esetén, amikor vizes oldatot préselnek az olaj szintje alá, és ezzel növelik meg a rétegnyomást. Ekkor tekintettel kell lennüik a mélyben uralkodó viszonyokra, hiszen a nagy különbség az olaj és a víz viszkozitásában nagy nyomás mellett azt eredményezné, hogy a víz néhány szélesebb csatornát vájva, egyszerúen keresztül folyna az olajon, és nem segítené annak felszínre hozását. 
Kísérleti munkám során az egymással érintkező, különböző sưrűségú folyadékok között kialakuló közegmozgást vizsgáltam. Ezen mérésekhez kézenfekvő a térben és időben lejátszatott autokatalitikus reakciók használata, ugyanis ekkor a reaktánsok és a termékek között egy éles határvonal - kémiai front - alakul ki, melynek két oldala között a súrúségkülönbség állandó. A rendszer tehát úgy viselkedik, mintha két, egymással nem elegyedő folyadék érintkezne. A vízszintesen haladó, kezdetben függóleges front az érintkező folyadékok sûrűségkülönbsége miatt elveszíti hidrodinamikai stabilitását és egy egycellás szerkezet jön létre. Anne De Wit és csoportja kétdimenzióra vonatkozó elméleti számítások alapján arra a következtetésre jutottak, hogy ezen struktúra jellemző paramétere - a keveredési hossz arányos a folyadék magasságának négyzetével.

Ezen összefüggés helyességének megállapításához kísérleteimet a klorit-tetrationát, hidrogénionra nézve autokatalitikus reakciót vékony folyadékrétegekben hajtottam végre. A reaktáns és a termék izoterm sưrúségviszonyairól elmondható, hogy a termékoldat sưrúsége a nagyobb, valamint fontos megemlíteni, hogy a reakció erősen exoterm, vagyis a termékoldat sûrúsége a felmelegedés közben csökken. A méréseket Hele-Shaw edényben játszattam le, amely két darab, egymástól egy változtatható méretú távtartóval elválasztott plexilapból áll. Ily módon a reakciót tetszóleges oldatvastagság és magasság esetén vizsgálhattam. A kísérletről felvételeket készítettem, melyek segítségével a front adott pillanatbeli helyzetét meg tudtam határozni. Az egymás utáni képek frontprofiljai alapján, az időbeni előrehaladást kiküszöbölve megadtam az átlagos frontprofilt, amiből az alakzat mennyiségi jellemzésére használt keveredési hossz - melyet az átlagos frontpozíció szórásaként definiáltunk - értékét számoltam ki. Megvizsgálva a keveredési hossz változását, miközben az oldat magassága $1 \mathrm{~cm}$-rôl 0,5 cm-enként 4 cm-re nő, az oldatvastagság pedig $1 \mathrm{~mm}$, azt tapasztaltam, hogy a kettô közötti kapcsolat hatványfüggvénnyel leírható ugyan, ám jelentôsen eltér az eredetileg jósolt négyzetes arányosságtól. Mérési eredményeim helyességét támasztotta alá D. Salin elméleti munkája, amelyben az oldatréteg vastagságának figyelembevételével határozta meg a keveredési hossz és rés magassága közötti kapcsolatot.

A reaktánsok kiindulási koncentrációját változtatva megállapítottam, hogy a négyzetes függés nem áll fent más koncentrációk esetén sem. Ezen kívül elmondható, hogy ha a kiindulási koncentrációkat növeljük, akkor a termékek és a reaktánsok közötti izoterm sûrúségkülönbségnek nőnie kell, vagyis a keveredési hossz növekedése lenne várható. Ezzel szemben azt tapasztaltam, hogy a keveredési hossz értékek csökkenek a koncentráció növelésével. A rendszert $3{ }^{\circ} \mathrm{C}$-ra termosztálva igazoltam, hogy ez a változás a növekvő koncentrációval együtt fokozódó mértékú hőfejlődés hatására a termékoldatban fellépő sûrúségcsökkenés következménye. Megmutattam, hogy termosztált körülmények között a keveredési hossz értéke független a kiindulási koncentrációtól, és a keveredési hossz és az edénymagasság közötti kapcsolatot leíró függvény hatványkitevője ezesetben is jelentősen eltér kettőtől. 
Kísérleteket végeztem szobahőmérsékleten különböző oldatvastagságok esetén is. Megfigyeltem, hogy a folyadékréteg vastagságát $3 \mathrm{~mm}$-re, vagy a fölé növelve a korábbiaktól eltérő, folytonosan keveredő alakzat jön létre, mely állandó profillal nem rendelkezik. A mérést $3{ }^{\circ} \mathrm{C}$-on végrehajtva az izoterm sûrúségviszonyoknak megfelelő front kialakulását tapasztaltam, ezzel bebizonyítottam, hogy a folytonosan változó mintázat a hőmérséklet hatásaként állt elő. Megállapítottam, hogy termosztált körülmények között az oldatréteg vastagságának növekedésével az alakzatok egyre elnyúltabbá válnak, vagyis a keveredési hossz értéke nő, ugyanakkor az edény magasságától való függés ezen esetekben sem négyzetes. A kísérleti eredmények és az elméletileg jósolt érték közötti különbség abban keresendő, hogy míg a számításokat milliméteres nagyságrendben végezték, addig a gyakorlatban alkalmazott reakcióedény méretei a centiméteres tartományba estek.

Mivel a folyadékok áramlása sok esetben pórusos közegben megy végbe, megvizsgáltam, hogy milyen hatást fejt ki a reakcióban kialakuló frontprofilra, ha nem homogén hanem pórusos rendszerben halad. Ezen kísérleteket is Hele-Shaw edényben végeztem el, melyet mérésenként más-más méretű gyöngyökkel töltöttem fel. A korábbi tapasztalatokra alapozva a reaktánsok kiindulási koncentrációját és az edénymagasságot állandó értéken tartottam és az egész rendszert termosztáltam. Elmondható, hogy a keveredési hossz értéke a homogén közegú kísérletekhez képest jelentősen lecsökkent, valamint pórusos közeg esetén a gyöngyök méretének növelésével az alakzat egyre elnyúltabbá vált. Megmutattam, hogy a keveredési hossz ezen növekedése a közeg permeabilitásának növekedésével indokolható, ugyanakkor a rendszer porozitása az alkalmazott gyöngyök méretétôl függetlenül végig állandó, tehát nem lehet felelős a frontprofil módosulásáért. A mérési eredmények alapján skálázási összefüggést írtam fel a keveredési hossznak az edénymagasságtól és a közeg permeabilitásától való függésére.

A klorit-tetrationát frontreakcióban a termékek és a reaktánsok közötti sûrúségkülönbség hatására kialakuló határfelület kvázi kétdimenziós vizsgálatát követően feladatom volt a Pópity-Tóth Éva által ugyanezen reakcióban, háromdimenziós térben megfigyelt alakzat létrejöttének magyarázata. Éva megállapította, hogy egy kritikus folyadékvastagság felett állandó alakkal és sebességgel terjedő, bonyolult frontprofil jön létre, melynek jellegzetes, felülnézetből V alakú beszögellése az edény szélességétől függetlenül azonos szöggel rendelkezik [43]. Az oldatban kialakuló áramlási viszonyok feltérképezéséhez a részecskeképen alapuló sebesség-meghatározási eljárást alkalmaztuk, melyhez a kísérleti berendezést én állítottam össze. A kísérletről készült felvételeket kisebb részterületekre osztottuk, és két egymás után készült kép azonos részterülete közötti térbeli korrelációt a szürkeségi érték - hely függvények Fourier-transzformációjára vonatkozó összefüggés alapján állapítottuk meg. A korrelációs függvények maximumának helye meghatározta az adott térrészekhez tartozó elmozdulás vektorokat, melyek segítségével a teljes háromdimenziós reakciótér 
áramlási viszonyai megadhatók voltak. Az így kapott áramlási profil alapján a korábban megfigyelt háromdimenziós alakzat jellegzetes vonásai jól magyarázhatók. Megfigyeltem, hogy az oldat azon részeinek mozgását, melyek az edény falához közel helyezkednek el, egy hosszan elnyúló, a front elején erôteljesen lefelé áramló konvekciós gyưrú jellemzi. Ezen rétegekben a felfelé áramlás sokkal gyengébb és messze a front mögé nyúlik. Távolodva az edény szélétől a konvekciós gyưrű rövidül, és a front elején lévő erôteljes lefelé áramlás mellett egy igen erős felfelé áramlás is kialakul, ami a reaktánsoldat kék színének megjelenését magyarázza a reakciófront mögötti sárga, elreagált oldattal teli részben. A folyadék középső részein egy második konvekciós gyưrú is kialakul, melynek az iránya a front elején levôvel megegyező, és így egy összetett áramlás jön létre, amely a korábban tapasztalt felülnézeti V alak létrehozásáért felelős. 


\section{8. fejezet}

\section{Summary}

The world surrounding us is in constant motion from the level of bacteria to the level of cyclones with a size of a continent. There are many motions which have no influence on our life directly but we can observe them easily (e.g. a leaf falling down from a tree) and there are many others that people cannot see but they have a very important influence (e.g. the dissipation of water soluble pollutants in the soil). The drifting of tectonic plates is very slow but it has a serious consequence on the everyday life of people living in that area because this event can be the cause of many seismic activities and tsunamis. Thus, it is absolutely evident that deeper scientific understanding of these movements is essential. Even though the time scales vary from seconds to years, the common property behind them is that material is transported from one place to another.

Diffusion due to concentration gradients, migration of ions in an electric field, and convection in the presence of the gravity field of the Earth are the major transport processes of matter. The driving force of convection in a medium can be the difference in viscosity, surface tension, or density between the two fluids in contact. A very good example is the Marangoni instability where fluid motion is induced by the change of surface tension along the liquid/gas interface. The essence of the phenomenon is that the fluid with greater surface tension pulls the other one along the interface. One of the most known case is the phenomenon called „Tears of wine” where water with greater surface tension pulls back the volatile alcohol resulting in a nice symmetric structure. The difference in the viscosity between oil and water has a very important role in the secondary mining process of oil recovery. Water is pumped below the oil level to reach the suitable pressure to retrieve as much oil as possible. Miners have to add chemicals to water to achieve an appropriate viscosity difference between the two fluids to avoid tunneling problems.

Convection arising from density change between two miscible fluids was studied in my dissertation. Autocatalytic reaction is a very good choice to this type of experimental investigation because there is a narrow interface, the so-called chemical front, between the products 
and the reactants with a constant density difference between them. Thus, the system behaves in a sense like two immiscible liquids with a common interface. For a horizontally propagating front of a vertical interface, the initial planar shape is hydrodynamically unstable and a structure with a single convection roll may evolve. Anne De Wit and her co-workers using two-dimensional calculations reported that the characteristic parameter of the profile - defined as the mixing length - is proportional to the square of the fluid layer height.

The chlorite-tetrathionate autocatalytic system with hydrogen ion being the autocatalyst was used to investigate the validity of this relation experimentally. The product solution has a greater density than the reactants under isothermal conditions. Since the reaction is strongly exothermic, the density of the products decreases locally behind the front. The experiments were carried out in Hele-Shaw reaction vessels which consist of two parallel Plexiglas plates with a spacer separating them. The size of the gap, and hence the reaction volume, was varied by changing the thickness of the spacer. Pictures were captured during the experiment with a suitable time resolution and the position of the reaction front was determined in every image using a computer-controlled imaging system. The average front profile was determined from the constant front profiles by setting the average position to zero, thus eliminating the propagation with constant speed. The mixing length - defined as the standard deviation of the average front position - was used to quantitatively describe the constant shape of the reaction. This characteristic parameter was investigated by increasing the height of the vessel from $1 \mathrm{~cm}$ to $4 \mathrm{~cm}$ with a step of $0.5 \mathrm{~cm}$ and keeping the width of the fluid constant $(1 \mathrm{~mm})$. A power function dependence was found between the mixing length and the height of the liquid but there was a significant difference from the theoretically predicted power exponent of two.

By changing the reactant concentration, it was observed that the relation cannot be written as a quadratic function. The isothermal density difference between the reactants and the products is increasing with the initial concentration of the reactant solution, hence a larger convection ring should evolve in these situations. However, the mixing length was decreasing with the increasing initial concentrations, so the entire system was thermostated at $3^{\circ} \mathrm{C}$ to prove that this behavior was caused by the heat effect which decreases the density of the products. The mixing length was independent on the initial concentration at this low temperature and the power of the function characterizing the dependence between the mixing length and the height of the liquid layer was $1.19 \pm 0.04$.

Experiments were also carried out by increasing the solution thickness at room temperature. A continuously changing shape was observed when the thickness of the reaction vessel was greater than $3 \mathrm{~mm}$. However, the patterns became constant when the system was thermostated at $3^{\circ} \mathrm{C}$ because the heat effects were again eliminated. The mixing length increased with the width of the gap and the exponent of the scaling function between the mixing length 
and the height of the vessel significantly differed from two.

In all cases, the difference between the experimental data and the theoretical predictions can be explained by considering the size of the liquid layer. The physical dimensions were in the millimeter range in the calculations, while our system in the experiments was in the order of centimeters, hence the drag at the boundary has much less contribution to the flow pattern.

The convective flow also was investigated quantitatively in porous media because this is more typical in real systems. Hele-Shaw reaction vessels were filled up with beads of diameters varied between 1 and $5 \mathrm{~mm}$. The initial concentration and the height of the vessel were kept constant and the entire setup was thermostated. The mixing length of the patterns propagating with constant shape and velocity was significantly smaller in the porous medium than in the homogeneous liquid layer and it increased on increasing bead size. The porosity of this close packed system was independent of the bead diameter, therefore it did not have any influence on the front profiles. On the other hand the permeability increased when the bead size increased, hence it had a significant effect on the shape and on the mixing length. The scaling law describing the mixing length as a function of solution height and the permeability of the system was determined experimentally.

The convection was also investigated in three dimensions in the chlorite-tetrathionate system. Experiments were carried out by Éva Pópity-Tóth in the same system where she found a very complex pattern of constant shape propagating with a constant velocity. My aim was to explore the three dimensional flow field to explain the evolution of the front profile. Éva observed that the front was constant if the width of the liquid was greater than a critical value. Furthermore, there was a V shaped formation - from top view - behind the leading edge of the front and the angle of it was independent of the width of the vessel. Particle Image Velocimetry was used to investigate the fluid motion and my job was to construct the experimental setup. In this method the light scattered by small particles that follow the flow of the liquid was captured by a camera. The pictures were then divided into smaller interrogation windows, and the spatial correlation function between these interrogation windows in subsequent images was calculated by using the Fourier-transforms of the gray scale field. The maximum position of the correlation function determined the displacement associated with the motion in the selected interrogation window and the entire three dimensional flow field was created by using these vectors. This vector field could well explain the evolution of the characteristic regions of the observed shape visible by naked eye. At the side walls the flow was dominated by one large convection ring with a strong downward flow at the tip of the front. However, the upward flow was weaker and far behind the front. Away from the walls the downward flow at the tip of the front remained however there was a strong return creating a smaller convection ring. This ascending of the warmer solution lead to the blue 
color, corresponding to the reactants, that was visible from above behind the leading edge of the front. In the middle of the liquid layer a second convection ring arised that rotated in the same direction as the first one and modified the flow in the wake of the front, since it created a cusp, hence responsible for the evolution of the constant V shape. 


\section{Irodalomjegyzék}

[1] P. W. Atkins, Fizikai kémia III: Változás, Tankönyvkiadó, Budapest (1992).

[2] G. Póta, G. Stedman, Exotic behaviour of chemical reaction systems, Models in Chemistry 131, 229-268 (1994).

[3] R. Arnold, K. Showalter, J. J. Tyson, Propagation of chemical reactions in space, J. Chem. Edu. 64, 740-742 (1987).

[4] K. Showalter, J. J. Tyson, Luther's 1906 discovery and analysis of chemical waves, J. Chem. Edu. 64, 742-744 (1987).

[5] L. Szirovicza, I. Nagypál, E. Boga, An algorithm for the design of propagating acidity fronts, J. Am. Chem. Soc. 111, 2842-2845 (1989).

[6] L. Szirovicza, I. Nagypál, E. Boga, Savas frontreakciók tervezése, Magyar Kémiai Folyóirat 96, 72-77 (1990).

[7] D. Horváth, K. Showalter, Instabilities in propagating reaction-diffusion fronts of the iodatearsenous acid reaction, J. Chem. Phys. 102, 2471-2478 (1995).

[8] K. Showalter, Quadratic and cubic reaction-diffusion fronts, Nonlinear Science Today 4, 3-10 (1995).

[9] Á. Tóth, I. Lagzi, D. Horváth, Pattern formation in reaction-diffusion systems: cellular acidity fronts, J. Phys. Chem. 100, 14837-14839 (1996).

[10] É. Jakab, D. Horváth, Á. Tóth, J. H. Merkin, S. K. Scott, The effect of reversible binding of the autocatalyst on the lateral instability of reaction fronts, Chem. Phys. Lett. 342, 317-322 (2001).

[11] I. Szalai, P. De Kepper, Patterns of the ferrocyanide-iodate-sulfite reaction revisited: the role of immobilized carboxylic functions, J. Phys. Chem. Lett. A 112, 783-786 (2008).

[12] Á. Tóth, D. Horváth, W. van Saarlos, Lateral instabilities of cubic autocatalytic reaction fronts in a constant electric field, J. Chem. Phys. 111, 10964-10968 (1999). 
[13] Zs. Virányi, Á. Tóth, D. Horváth, Lateral instability induced by an inhomogeneous electric field, Chem. Phys. Lett. 401, 575-578 (2005).

[14] G. G. Cascado, L. Tofaletti, D. Mülller, A. D’Onofrio, Rayleighr-Taylor instabilities in reactiondiffusion systems inside Hele-Shaw cell modified by the action of temperature, J. Chem. Phys. 126, 114502 (2007).

[15] L. Macias, D. Müller, A. D'Onofrio, Influence of porosity on Rayleigh-Taylor instabilities in reaction-diffusion systems, Phys. Rev. Lett. 102, 094501 (2009).

[16] A. Hana, A. Saul, K. Showalter, Detailed studies of propagating fronts in the iodate oxidation of arsenous acid, J. Am. Chem. Soc. 104, 3838-3844 (1982).

[17] L. Rayleigh, Investigation of the character of the equilibrium of an incompressible heavy fluid of variable density, Proc. Math. Soc. 14, 170-177 (1883).

[18] G. I. Taylor, The instability of liquid surfaces when accelerated in a direction perpendicular to their planes. I., Proc. Roy. Soc. A 201, 192-196 (1950).

[19] D. J. Lewis, The instability of liquid surfaces when accelerated in a direction perpendicular to their planes. II., Proc. Roy. Soc. A 202, 81-96 (1950).

[20] J. A. Pojman, I. R. Epstein, Convective effects on chemical waves. 1. Mechanisms and stability criteria, J. Phys. Chem. 94, 4966-4972 (1990).

[21] T. A. Gribschaw, K. Showalter, D. L. Banville, I. R. Epstein, Chemical waves in the acidic iodate oxidation of arsenite, J. Phys. Chem. Lett. 85, 2152-2155 (1981).

[22] C. Normand, Y. Pomeau, M. G. Velarde, Convective instability: A physicist's approach, Rev. Mod. Phys. 49, 581-624 (1977).

[23] W. A. Tokaruk, T. C. A. Molteno, S. W. Morris, Bénard-Marangoni convection in two-layered liquids, Phys. Rev. Lett. 84, 3590-3593 (2000).

[24] Gy. Bazsa, I. R. Epstein, Traveling waves in the nitric acid-iron(II) reaction, J. Phys. Chem. 89, 3050-3053 (1985).

[25] I. Nagypál, Gy. Bazsa, I. R. Epstein, Gravity-induced anisotropies in chemical waves, J. Am. Chem. Soc. 108, 3635-3640 (1986).

[26] J. A. Pojman, I. R. Epstein, T. J. McManus, K. Showalter, Convective effects on chemical waves. 2. Simple convection in the iodate-arsenous acid system, J. Phys. Chem. 95, 1299-1306 (1991).

[27] J. A. Pojman, I. P. Nagy, I. R. Epstein, Convective effects on chemical waves. 3. Multicomponent convection in the iron(II)-nitric acid system, J. Phys. Chem. 95, 1306-1311 (1991). 
[28] A. Keresztessy, I. P. Nagy, Gy. Bazsa, J. A. Pojman, Traveling waves in the iodate-sulfite and bromate-sulfite systems, J. Phys. Chem. 99, 5379-5384 (1995).

[29] I. P. Nagy, A. Keresztessy, J. A. Pojman, Periodic convection in the bromate-sulfite reaction: a ”Jumping" wave, J. Phys. Chem. 99, 5385-5388 (1995).

[30] J. A. Pojman, A. Komlósi, I. P. Nagy, Double-diffusive convection in traveling waves in the iodate-sulfite system explained, J. Phys. Chem. 100, 16209-16212 (1996).

[31] A. Komlósi, I. P. Nagy, Gy. Bazsa, J. A. Pojman, Convective chemical fronts in the 1,4cyclohexanedione-bromate-sulfuric acid-ferroin system, J. Phys. Chem. A 102, 9136-9141 (1998).

[32] M. Böckmann, S. C. Müller, Growth rates of the buoyancy-driven instability of an autocatalytic reaction front in a narrow cell, Phys. Rev. Lett. 85, 2506-2509 (2000).

[33] T. Bánsági, Jr., D. Horváth, Á. Tóth, Nonlinear interactions in the density fingering of an acidity front, J. Chem. Phys. 121, 11912-11915 (2004).

[34] T. Rica, D. Horváth, Á. Tóth, Density fingering in acidity fronts: Effect of viscosity, Chem. Phys. Lett. 408, 422-425 (2005).

[35] T. Tóth, D. Horváth, Á. Tóth, Thermal effects in the density fingering of the chloritetetrathionate reaction, Chem. Phys. Lett. 442, 289-292 (2007).

[36] L. Šebestíková, J. D’Hernoncourt, M. J. B. Hauser, S. C. Müller, A. De Wit, Flow-field development during finger splitting at an exothermic chemical reaction front, Phys. Rev. E 75, 026309 (2007).

[37] A. De Wit, Miscible density fingering of chemical fronts in porous media: Nonlinear simulations, Phys. Fluids 16, 163-175 (2004).

[38] N. Jarrige, I. Bou Malham, J. Martin, N. Rakotomalala, D. Salin, L. Talon, Numerical simulations of a buoyant autocatalytic reaction front in tilted Hele-Shaw cells, Phys. Rev. E 81, 066311 (2010).

[39] L. Rongy, G. Schuszter, Z. Sinkó, T. Tóth, D. Horváth, Á. Tóth, A. De Wit, Influence of thermal effects on buoyancy-driven convection around autocatalytic chemical fronts propagating horizontally, Chaos 19, 023110 (2009).

[40] G. Schuszter, T. Tóth, D. Horváth, Á. Tóth, Convective instabilities in horizontally propagating vertical chemical fronts, Phys. Rev. E 79, 016216 (2009).

[41] G. Schuszter, D. Horváth, Á. Tóth, Convective instabilities of chemical fronts in close-packed porous media, Chem. Phys. Lett. 546, 63-66 (2012). 
[42] L. Šebestíková, M. J. B. Hauser, Buoyancy-driven convection may switch between reactive states in three-dimensional chemical waves, Phys. Rev. E 85, 036303 (2012).

[43] É. Pópity-Tóth, D. Horváth, Á. Tóth, Horizontally propagating three-dimensional chemohydrodynamic patterns in the chlorite-tetrathionate reaction, Chaos 22, 037105 (2012).

[44] J. Huang, D. A. Vasquez, B. F. Edwards, P. Kolodner, Onset of convection for autocatalytic reaction fronts in a vertical slab, Phys. Rev. E 48, 4378-4386 (1993).

[45] D. A. Vasquez, J. M. Littley, J. W. Wilder, B. F. Edwards, Convection in chemical waves, Phys. Rev. E 50, 280-284 (1994).

[46] J. Yang, A. D’Onofrio, S. Kalliadasis, A. De Wit, Rayleigh-Taylor instability of reactiondiffusion acidity fronts, J. Chem. Phys. 117, 9395-9408 (2002).

[47] D. A. Vasquez, A. De Wit, Dispersion relations for the convective instability of an acidity front in Hele-Shaw cells, J. Chem. Phys. 121, 935-941 (2004).

[48] D. Horváth, T. Bánsági Jr., Á. Tóth, Orientation-dependent density fingering in an acidity front, J. Chem. Phys. 117, 4399-4402 (2002).

[49] L. Rongy, N. Goyal, E. Meiburg, A. De Wit, Buoyancy-driven convection around chemical fronts traveling in covered horizontal solution layers, J. Chem. Phys. 127, 114710 (2007).

[50] J. D'Hernoncourt, A. Zebib, A. De Wit, On the classification of buoyancy-driven chemohydrodynamic instabilities of chemical fronts, Chaos 17, 013109 (2007).

[51] S. Hill, Channelling in packed columns, Chem. Eng. Sci. 1, 247-253 (1952).

[52] P. G. Saffman, G. Taylor, The penetration of a fluid into a porous medium or Hele-Shaw cell containing a more viscous liquid, Proc. Roy. Soc. A 245, 312-329 (1958).

[53] A. De Wit, G. M. Homsy, Viscous fingering in periodically heterogeneous porous media. I. Formulation and linear stability, J. Chem. Phys. 107, 9609-9618 (1997).

[54] A. De Wit, G. M. Homsy, Viscous fingering in periodically heterogeneous porous media. II. Numerical simulations, J. Chem. Phys. 107, 9619-9628 (1997).

[55] E. Lajeunesse, J. Martin, N. Rakotomalala, D. Salin, 3D instability of miscible displacements in a Hele-Shaw cell, Phys. Rev. Lett. 79, 5254-5257 (1997).

[56] I. Bou Malham, N. Jarrige, J. Martin, N. Rakotomalala, L. Talon, D. Salin, Lock-exchange experiments with an autocatalytic reaction front, J. Chem. Phys. 133, 244505 (2010).

[57] C. Marangoni, Ueber die Ausbreitung der Tropfen einer Flüssigkeit auf der Oberfläche einer anderen, Annalen der Physik und Chemie 143, 337-354 (1871). 
[58] L. Rongy, A. De Wit, Steady Marangoni flow traveling with chemical fronts, J. Chem. Phys. 124, 164705 (2006).

[59] L. Rongy, A. De Wit, Solitary Marangoni-driven convective structures in bistable chemical systems, Phys. Rev. E 77, 046310 (2008).

[60] L. Rongy, Influence of Marangoni and buoyancy convection on the propagation of reactiondiffusion fronts, $\mathrm{PhD}$ disszertáció, Brüsszel (2008).

[61] S. Atis, S. Saha, H. Auradou, J. Martin, N. Rakotomalala, L. Talon, D. Salin Chemohydrodynamic coupling between forced advection in porous media and self-sustained chemical waves, Chaos 22, 037108 (2012).

[62] S. Saha, S. Atis, D. Salin, L. Talon, Phase diagram of sustained wave fronts opposing the flow in disordered porous media, Expl. Front. Phys. 101, 38003 (2013).

[63] S. Atis, S. Saha, H. Auradou, J. Martin, D. Salin, L. Talon, Autocatalytic reaction fronts inside a porous medium of glass spheres, Phys. Rev. Lett. 110, 148301 (2013).

[64] J. T. H. Andres, S. S. S. Cardoso Onset of convection in a porous medium in the presence of chemical reaction, Phys. Rev. E 83, 046312 (2011).

[65] A. K. Horváth, I. Nagypál, G. Peintler, I. R. Epstein, Autocatalysis and self-inhibition: coupled kinetic phenomena in the chlorite-tetrathionate reaction, J. Am. Chem. Soc. 126, 6246-6247 (2004).

[66] A. K. Horváth, I. Nagypál, I. R. Epstein, Three autocatalysts and self-inhibition in a single reaction: A detailed mechanism of the chlorite-tetrathionate reaction, Inorg. Chem. 45, $9877-$ 9883 (2006).

[67] D. Varga, A. K. Horváth, Kinetics and mechanism of the decomposition of the tetrathionate ion in alkaline medium, Inorg. Chem. 46, 7654-7661 (2007).

[68] M. Fuentes, M. N. Kuperman, P. De Kepper, Propagation and interaction of cellular fronts in a closed system, J. Phys. Chem. 105, 6769-6774 (2001).

[69] A. Tonddast-Navæi, Acoustic particle image velocimetry, PhD disszertáció, Open University, UK (2008).

[70] M. Raffel, C. E. Willert, S. T. Wereley, J. Kompenhans, Particle Image Velocimerty: A Pratical Guide, Springer, Berlin (2007).

[71] W. Lauterborn, A. Vogel, Modern optical techniques in fluid mechanics, Ann. Rev. Fluid. Mech. 16, 223-244 (1984). 
[72] T. D. Dudderar, P. G. Simpkins, Laser speckle photography in a fluid medium, Nature 270, 45-47 (1977).

[73] D. B. Barker, M. E. Fourney, Measuring fluid velocities with speckle patterns, Opt. Lett. 1, 135-137 (1977).

[74] R. Grousson, S. Mallick, Study of flow pattern in a fluid by scattered laser light, App. Opt. 16, 2334-2336 (1977).

[75] P. Buchhave, Particle image velocimetry - status and trends, Exp. Thermal Fluid Sci. 5, 586604 (1992).

[76] I. Grant, G. H. Smith, Modern developments in particle image velocimetry, Opt. Lasers Eng. 9, 245-264 (1988).

[77] R. J. Adrian, Twenty years of particle image velocimetry, Exp. in Fluids 39, 159-169 (2005).

[78] Az internetes jegyzet elérhetősége:

www.reak.bme.hu/uploads/media/12_PIV_gyakorlat.pdf

[79] S. P. McKenna, W. R. McGillis, Performance of digital image velocimetry processing techniques, Exp. in Fluids 32, 106-115 (2002).

[80] F. Champagnat, A. Plyer, G. Le Besnerais, B. Leclaire, S. Davoust, Y. Le Sant, Fast and accurate PIV computation using highly parallel iterative correlation maximization, Exp. in Fluids 50, 1169-1182 (2011).

[81] S. Satake, G. Sorimachi, N. Masuda, T. Ito, Special-purpose computer for particle image velocimetry, Comp. Phys. Comm. 182, 1178-1182 (2011).

[82] J. P. Prenel, R. Porcar, A. El Rhassouli, Three-dimensional flow analysis by means of sequential and volumic laser sheet illumination, Exp. in Fluids 7, 133-137 (1989).

[83] J. P. Prenel, D. Ambrosini, Flow visualization and beyond, Opt. and Lasers in Eng. 50, 1-7 (2012).

[84] K. Eckert, M. Acker, Y. Shi, chemical pattern formation driven by a neutralization reaction. I.Mechanism and basic features, Phys. of Fluids 16, 385-399 (2004).

[85] É. Pópity-Tóth, Diffúzív és konvektív instabilitás tanulmányozása autokatalitikus reakciófrontokban, PhD disszertáció, Szeged (2012).

[86] T. Bánsági Jr., D. Horváth, Á. Tóth, Multicomponent convection in the chlorite-tetrathionate reaction, Chem. Phys. Lett. 384, 153-156 (2004).

[87] http://www.dictall.com/picture/bkimg/ch_143/143_23_17_0.jpg 


\section{Köszönetnyilvánítás}

Ezúton szeretném megköszönni szüleimnek, hogy iskoláim elvégzéséhez minden anyagi és családi hátteret bőségesen biztosítottak, és fáradtságot nem kímélve úgy neveltek, hogy az hasznomra váljon. Hálás vagyok főnökeimenk, Áginak és Dezsônek, a belém fektetett sok munkáért, időért, baráti bizalomért, és köszönöm, hogy igyekeztek belőlem a lehető legtöbbet kihozni. Külön szeretnék köszönetet mondani Adriank, a feleségemnek, hogy sosem tartott vissza a céljaim elérésétôl és bíztatott akkor is, amikor magamtól már belefáradtam volna. Végezetül, hála legyen Istennek a sok eróért és útmutatásért amit adott és ad folyamatosan. 